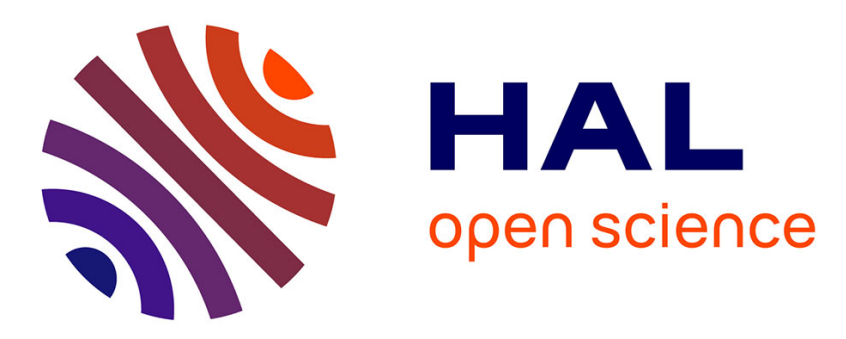

\title{
A Survey of Place-Names in the Egyptian Eastern Desert during the Principate according to the Ostraca and the Inscriptions
}

Hélène Cuvigny

\section{- To cite this version:}

Hélène Cuvigny. A Survey of Place-Names in the Egyptian Eastern Desert during the Principate according to the Ostraca and the Inscriptions. Jean-Pierre Brun, Thomas Faucher, Bérangère Redon and Steven Sidebotham. The Eastern Desert of Egypt during the Greco-Roman Period: Archaeological Reports, Collège de France, 2018, 10.4000/books.cdf.5231 . halshs-02975619

\section{HAL Id: halshs-02975619 \\ https://shs.hal.science/halshs-02975619}

Submitted on 22 Oct 2020

HAL is a multi-disciplinary open access archive for the deposit and dissemination of scientific research documents, whether they are published or not. The documents may come from teaching and research institutions in France or abroad, or from public or private research centers.
L'archive ouverte pluridisciplinaire HAL, est destinée au dépôt et à la diffusion de documents scientifiques de niveau recherche, publiés ou non, émanant des établissements d'enseignement et de recherche français ou étrangers, des laboratoires publics ou privés. 


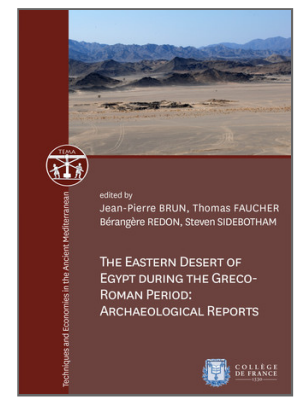

Jean-Pierre Brun, Thomas Faucher, Bérangère Redon and Steven Sidebotham (dir.)

The Eastern Desert of Egypt during the Greco-Roman Period: Archaeological Reports

Collège de France

\section{A Survey of Place-Names in the Egyptian Eastern Desert during the Principate according to the Ostraca and the Inscriptions}

\section{Hélène Cuvigny}

DOI: 10.4000/books.cdf.5231

Publisher: Collège de France

Place of publication: Paris

Year of publication: 2018

Published on OpenEdition Books: 14 September 2018

Serie: Institut des civilisations

Electronic ISBN: 9782722604889

\section{Sbooks}

http://books.openedition.org

Brought to you by Collège de France

COLLE GE

DE FRANCE

Electronic reference

CUVIGNY, Hélène. A Survey of Place-Names in the Egyptian Eastern Desert during the Principate according to the Ostraca and the Inscriptions In: The Eastern Desert of Egypt during the Greco-Roman Period: Archaeological Reports [online]. Paris: Collège de France, 2018 (generated 22 octobre 2018). Available on the Internet: <http://books.openedition.org/cdf/5231>. ISBN: 9782722604889. DOI: 10.4000/ books.cdf.5231. 


\title{
A Survey of Place-Names in the Egyptian Eastern Desert during the Principate according to the Ostraca and the Inscriptions ${ }^{1}$
}

\author{
Hélène Cuvigny
}

1 The sole purpose of this study is to take stock of the progress made on the toponymy of the Eastern Egyptian Desert through the ostraca found in the excavations of Roman sites in which I took part between 1987 and 2012 (Fig. 1). Ostraca, published and unpublished, to which I will refer, come from the quarry sites of Mons Claudianus and Domitiane/Kaine Latomia (Umm Balad), two forts (praesidia) on the road from Koptos to Myos Hormos (Maximianon and Krokodilo), and three praesidia on the road from Koptos to Berenike (Didymoi, Dios and Xeron). I occasionally take into account the ostraca of Porphyrites and Myos Hormos. ${ }^{2}$ I also refer to names read on Greek ostraca found recently in Bi'r Samut, a fort along the road from Apollonos Polis (Edfu) to Berenike; Bi'r Samut was founded under Ptolemy II or III, and abandoned under Ptolemy IV. ${ }^{3}$ 
Fig. 1
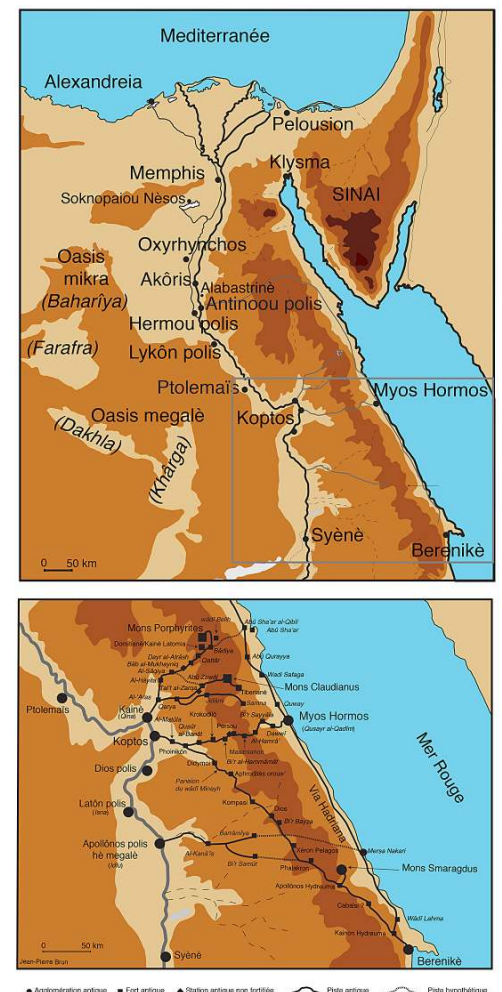

The Eastern Desert in Roman times.

(c) JEAN-PIERRE BRUN

These documents, many of which are still unpublished, have yielded a small corpus of new or already known toponyms, but some of the latter had been distorted by the Medieval manuscript tradition. The classical main sources on place-names in the Eastern Desert up to now were:

- the description of the road from Koptos to Berenike by Pliny the Elder, informed by negotiatores, in the state in which it was found in AD 50, i.e. before the wells (hydreumata) were fortified into praesidia under Vespasian (Nat. 6.102-103);

- the list of stages on this route in three itineraries taken from the manuscript tradition: Antonine Itinerary (172-173 ed. Parthey, Pinder), Peutinger Table, Anonymous of Ravenna (2.7.4 ed. Schnetz).

- Ptolemy's Geography for the coast of the Red Sea (4.5.14-15) and the desert (4.5.27). ${ }^{4}$

\section{The Administrative districts of the Eastern Desert under the Early Roman Empire}

Our ostraca come from a geographical area, which, in the Roman period, seems to have consisted of two distinct administrative sectors with different purposes. The most southerly is the best defined and the one for which the administrative structure is the most stable and the best known. The Romans called it Mons Berenicidis or Mons Berenices, which does not mean "Mountain", but "Desert of Berenike," the Latin mons being, through the Greek öpoc, the loan translation of an Egyptian word, $d w$, which means both desert and mountain. ${ }^{5}$ The Desert of Berenike, named after its most active port, was 
crossed by the roads to Myos Hormos and Berenike, both of which departed from the Nile valley at Koptos. They represented a terrestrial segment of one of the main trade routes with the Erythraean world. From Vespasian's time, they were equipped with fortified wells, each headed by a curator praesidii. The curators were placed under the direct authority of the prefect of Berenike, who was an imperial procurator. These territorial prefects, whose prosopography has been enriched, often added to their procuratorship a military command, the prefecture of the cavalry wing stationed in Koptos.

In the ostraca of the aforementioned sites, the road to Myos Hormos seems to mark the northern limit of the Berenike desert. Nevertheless, there is a reference to a prefect of Berenike north of this road: this is the dedication of the Paneion of Ophiates, a Roman granite quarry in the Wadi Umm Wikala, a tributary of the Wadi Samna (I.Pan 51); 6 it dates from year 40 of Augustus' reign (AD 11) and specifies the name of the prefect in power, Publius Iuventius Rufus, who combines this function with that of archimetallarches, that is to say, commander in chief of mines and quarries. In AD 11, Mons Claudianus and Porphyrites have yet to open, and the mineral resources specifically mentioned (and identified) in the prefect's titulature, Smaragdos and Bazion, ${ }^{7}$ lay south of the Wadi Samna. The inscription, therefore, contains the most northerly mention of a prefect of Berenike: in fact, there is never any mention of this official in the ostraca of the granite and porphyry quarries which the Romans opened later: Porphyrites, Tiberiane, Mons Claudianus, Domitiane/Kaine Latomia. Was this northern area of the Eastern Desert even an administrative entity? It is not clear, as we shall see.

The exploitation of Mons Claudianus granite and the porphyry of the Porphyrites caused the Romans to reorganize the road system this region, which had been explored before the Romans. Gold deposits had been exploited under the New Kingdom and under the Ptolemies in the area of what would become Mons Claudianus, especially between the current Qena-Safaga road and Myos Hormos road; 8 in this segment of the Eastern Desert, there are also the amethyst mines of Abu Diyayba, exploited under Ptolemy VI and still active at the beginning of the Empire. Prior to the founding of Kaine (Qena), which served as a terminus for the Claudianus and Porphyrites roads, the mining sites north of Myos Hormos road must have been administered and provisioned from Koptos, and belonged presumably to what was called in Egyptian $\underline{d} w$ Gbtyw, the Desert of Koptos. This is the reason why, in my opinion, at the beginning of the Empire, and before the founding of Kaine, the Berenike Desert includes Ophiates, an early Roman granite quarry north of what later appears as the northern border of Mons Berenicidis.

6 The opening of quarries at Porphyrites and Claudianus caused new logistical problems: it was not a question of taxing and transporting valuable products, but of extracting multiton monoliths and transporting them over a hundred kilometres to the Nile: the development of a closer embarkation site was necessary and the area, served by its own road system, had no reason to be commanded by a prefect of Berenike exercising his authority from Koptos. It was no longer about placing "all the mines and quarries of Egypt" under his authority. The ostraca from the four metalla that have been excavated, Claudianus, Porphyrites and their satellites (Tiberiane and Domitiane/Kaine Latomia), show that these quarries functioned as a network; the staff and labour force were moved, as needed, from one site to the other. But did this region have a name? A series of ostraca from Mons Claudianus, receipts for advances to the familia, ${ }^{9}$ allow us to suggest a hypothesis. 
7 The familia is one of two major categories of labour in the quarries of the area. The other consists of the pagani, who were highly qualified stone-carvers and blacksmiths of indigenous origin and free status. Of the two categories, the familia is the most enigmatic. This is, most likely, an imperial familia, so basically slaves of the emperor, but some of these individuals, who have patronymics or gentilicia, cannot have had servile status. Their variegated onomastics often denote an origin outside Egypt. In any case, the familia was employed in tasks that demanded more strength than technical knowledge. Some of these familiares lived on credit and received advances of food, for which they were made to sign receipts, on which appeared their administrative affiliation to a numerus and an arithmos. These two words, the first Latin, the second Greek, are synonymous in principle (they mean "number"), but in this case, the arithmos represents a subdivision of a numerus. In the ostraca from Mons Claudianus, members of the familia almost all belong to the numerus of Porphyrites and the arithmos of Claudianus; but a few, registered in the arithmos of Tiberiane, worked in this satellite of Claudianus. Two receipts for advances are exceptional: they are issued by individuals belonging to another numerus, that of Alabastron: ${ }^{10}$ they were probably registered in the rosters of the alabaster quarries of the Hermopolite, which reminds of the existence at Hermou Polis of an "office of the accountants of Porphyrites and other metalla." ${ }^{11}$ If we project the administrative structure of the familia on the map of the region, it seems that Porphyrites was not only the name of the metallon where porphyry was extracted, but referred also to the entire area that was penetrated by the two roads coming from Kaine.

8 This region of Porphyrites (which remains an hypothesis) did not have the same administrative structure as the Berenike Desert. It was not under the authority of a territorial prefect who would have been the counterpart of the prefect of Berenike. However, in some late ostraca from Claudianus, there appears the word ह̌ $\pi \alpha$ xоc, "prefect." It is, unfortunately, not clear whether this is a territorial prefect or the officer commanding a military unit, wing or cohort. This mysterious prefect forms a pair with an

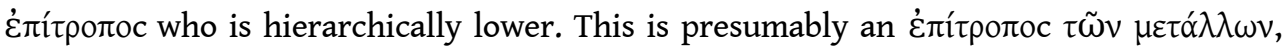
thus a procurator metallorum, who was an imperial freedman. We know the names of two of these prefects. One is called Vibius Alexandros. He receives a pessimistic letter addressed to him by a noncommissioned officer, left in charge of Mons Claudianus with the title of vice-curator and many logistical problems on his hands. ${ }^{12}$ The ostracon contains the draft of two letters from the vice-curator, one to the prefect, and a second one on the same subject addressed to the procurator metallorum Tertullus. The letters date from $5^{\text {th }}$ Phamenoth of year 29 of the reign of Commodus, or $1^{\text {st }}$ March AD 189. Vibius Alexandros happens to be known through a papyrus in Leipzig as the epistrategos of Heptanomia. In this capacity, he receives a petition dating from the first months of 189. The cumulation of an epistrategy -a procuratorial post specifically Egyptian- with a prefecture is not unique: there are two parallels, but they do not help to decide whether Vibius Alexandros owes his title of prefect to a unit command or to a territorial prefecture, since both cases are represented.

9 The name of the other prefect who has authority over Mons Claudianus is Antonius Flavianus. He is the recipient of two letters (drafts) written by the native quarrymen to announce that two columns are ready (with the help of Sarapis) and that they need to be sent steel and coal so that they can complete the third. ${ }^{13}$ This prefect is also assisted by a procurator. I was surprised to find Antonius Flavianus on an ostracon of the Berenike Desert, coming from the fort of Dios. The name of Antonius Flavianus in the dative fills 
the first line of the copy of a letter addressed to him by the curator of Dios. ${ }^{14}$ The sherd is a fragment of an amphora on which the curator copied the official correspondence, or perhaps just the letters he sent. In the latter case, it would be a liber litterarum missarum, but the state of the document does not allow us to be certain. The title of Antonius Flavianus does not appear, unfortunately. All I can say is that, when they are detached to the Berenike Desert, the curators have as their direct hierarchical superior the Prefect of Berenike, and that it is with this official that they exchange correspondence, except when it is of a purely local nature. Is it possible that the two areas I have distinguished in the Eastern Desert were, at a given moment, at the end of the second century or the beginning of the third, under the authority of a single Roman knight? The possibility remains open, but the state of the documentation does not allow us to say more. It may simply be a temporary situation, in which Antonius Flavianus acted as an interim Prefect of Berenike.

\section{Analytical classification of Greek and Latin toponyms}

10 To present the toponyms I will use a system of classification by topographical features. The rules for the formation of toponyms, their syntactic behaviour and thematic typology vary according to these features (this is not unique to Greek): metalla; quarries in the

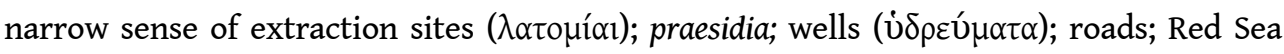
ports. The names bestowed by today's desert dwellers on the praesidia are sometimes those of the wadis in which they stand. The ostraca never mention names of features resorting to physical geography, such as wadis or mountains. Is it a bias of this kind of source, or did the men sent from the Nile valley, contrary to the Beduins of today, not bother to bestow names on such features? For these sedentary people, the desert may have been only a network of human settlements, joined by a limited number of much trodden roads. The same indifference to geography is reflected in the fact that no desert place name refers to geographic directions and is called Northern, Eastern etc. Something.

11 The names used in the Eastern Desert in the Imperial period are mainly known to us from Greek texts, more rarely from Latin ones. They were almost all created under the Ptolemies or under the Roman rule, so that some are Latin. Several are in other languages which we cannot always determine, and we do not know if they were assigned by the Romans or if they belong to an earlier toponymic substrate. ${ }^{15}$

For the analytical description of toponyms, I have used Dorion, Poirier 1975 and Löfström, Schabel-Le Corre 2005. In particular, I borrow from the latter the distinction between appellative and proprial, applied both to nouns and adjectives, for example:

Table 1

\begin{tabular}{|c|c|c|}
\hline & noun & adjective \\
\hline appellative & 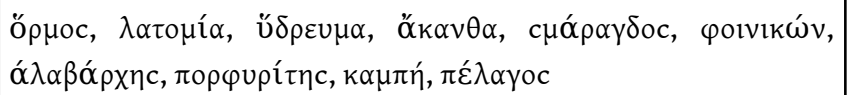 & 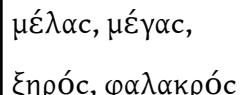 \\
\hline
\end{tabular}




\begin{tabular}{|c|c|c|}
\hline proprial & 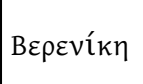 & 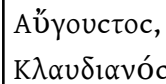 \\
\hline
\end{tabular}

\section{DISTINCTION BETWEEN APPELLATIVE AND PROPRIAL.}

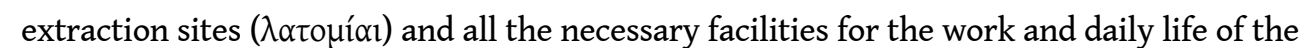
workers, military and administrative staff (dwelling places, offices, wells, stables, granaries, sanctuaries, forges, baths, etc.). When metallon designates one of these entities, it is, in the ostraca from Mons Claudianus, in the singular: $\dot{\varepsilon} v \mu \varepsilon \tau \alpha \dot{\alpha} \lambda \lambda \omega \mathrm{K} \lambda \alpha v \delta 1 \alpha v \tilde{\omega}$,

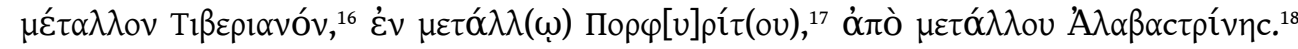
In the papyri, however, this generic is usually in the plural, even when referring to a

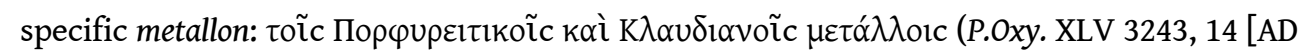
214/215]), $\tau \tilde{\omega} v$ א. in general, $\mu \varepsilon \dot{\tau} \tau \alpha \lambda$ ov is omitted. 


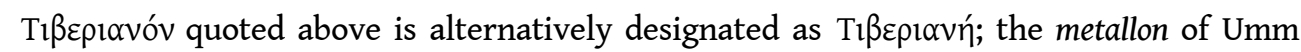

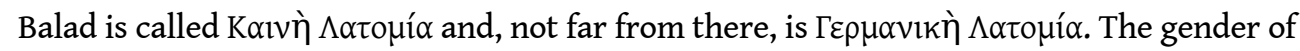

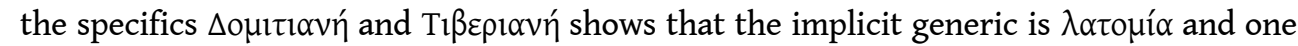
observes that if the dedication of Publius Agathopous in Ophiates evokes $\pi \alpha{ }^{\prime} v \tau \omega v \tau \tilde{\omega} v$

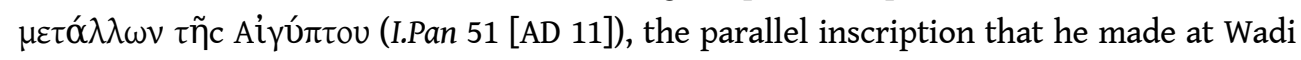

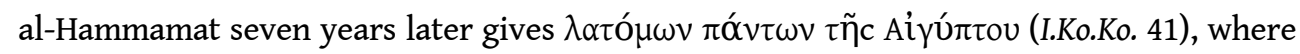
the abnormal phrase $\lambda \alpha \tau o ́ \mu \omega \nu \pi \alpha ́ v \tau \omega v$ is considered by Dittenberger, correctly in my view, as an error for $\lambda \alpha \tau o \mu \iota \tilde{\omega} v \pi \alpha c \tilde{\omega} v$.

Table 2

\begin{tabular}{|c|c|c|c|c|}
\hline Imperial reference & name of material & descriptive & anthropophore? & uncertain \\
\hline 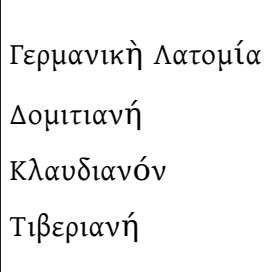 & 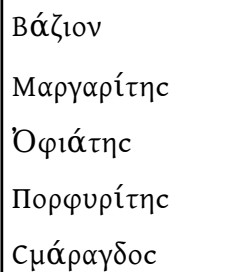 & 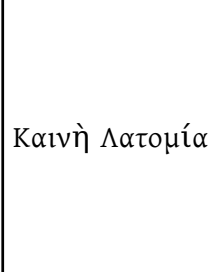 & $\begin{array}{l}\text { А } \lambda \alpha \beta \alpha ́ \alpha \rho \chi c \\
\Pi \varepsilon ́ \rho \operatorname{cov}^{19}\end{array}$ & 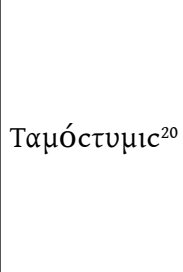 \\
\hline
\end{tabular}

Names of metalla in the Eastern Desert: semantic classification.

\section{A ghost: the complex toponym "Mons Porphyrites"}

The familiar names of Mons Claudianus and Mons Porphyrites are in fact poorly documented. For Mons Claudianus, there is only one example: the dedication in Latin, on an altar at Mons Claudianus by a centurion appointed directly by the emperor to be in

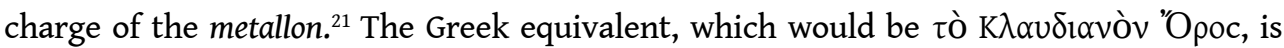

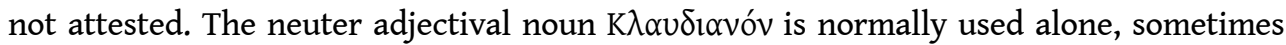
preceded by the article; in the rare cases where the generic, normally implicit, is expressed, it is $\mu \varepsilon \tau^{\tau} \alpha \lambda \lambda$ ov. Thus, in O.Claud. IV 853, a letter addressed collectively to Probus, procurator metallorum, the quarrymen working in the metallon of Claudianus call

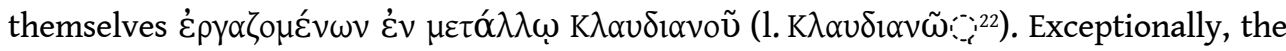
generic $\pi \rho \alpha ı c i ́ \delta 1$ ov replaces $\mu \varepsilon \tau^{\prime} \alpha \lambda \lambda$ ov: when, probably from the time of Antoninus Pius onwards, ${ }^{23}$ the commander of Mons Claudianus on site is no more a centurion, but a

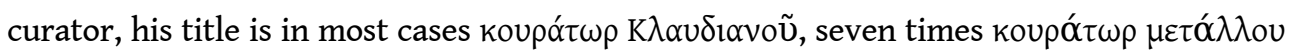

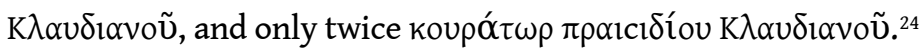

On the other hand, the Latin phrase Mons Porphyrites is not attested in any ancient sources. In papyrus documents, what we commonly call Mons Porphyrites is simply called

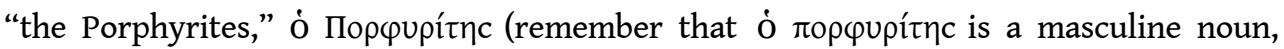
meaning "porphyry": we shall return to the toponymic use of names of materials). It is the same in the only Latin inscription that mentions it, despite its solemn character. It adorned the facade of the residence, situated at Hermou Polis, of the accountants of the mines and quarries: hosp(itium) tabula(riorum) Porphyr(itae) et aliorum metallorum. ${ }^{25}$ The complex toponym Mons Porphyrites has obviously been created in modern times, either from Latin translations of Ptolemy's Geography, dating from the Renaissance, or by 
analogy with Mons Claudianus (toponym regularly formed as: generic noun + proprial

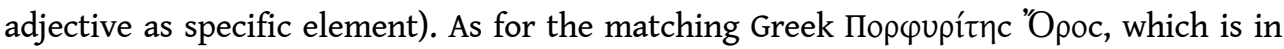
the list of Greek place names compiled by Redard, ${ }^{26}$ this is also not attested, at least not in the documentary sources (papyri and inscriptions). No wonder, since it contravenes the rules of the composition of complex toponyms in Greek: the specific element, if a noun (common as well as proper), is in the genitive. See Mvòc "O $\rho \mu o c,{ }^{27}{ }^{2} A \pi 0 ́ \lambda \lambda \omega v o c$ "Y $\delta \rho \varepsilon u \mu \alpha$,

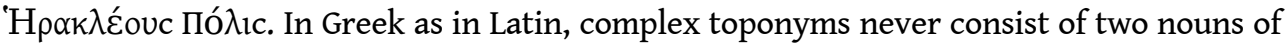
which one is in apposition to the other. But, what can we say about two passages, by

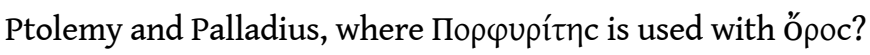

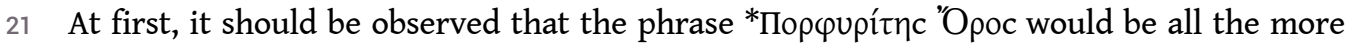
surprising in Greek as the two nouns are of different genders: a phrase indicating that $\dot{o}$

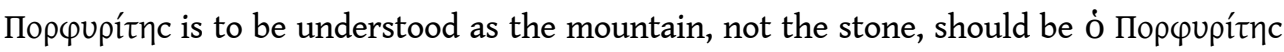
tò ôpoc ("the Porphyrites mountain"). Ptolemy's Geography, as it came to us, more or less respects this rule in constructed sentences or after a preposition, not -at least in appearance- in the table of ground coordinates. For example: ó Парvaccòc öpoc, but

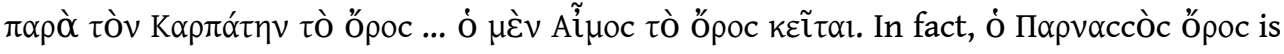
not a phrase, but ópoc is only a gloss directed to the person who is drawing the map.

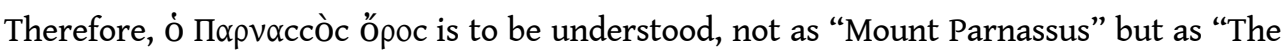
Parnassus (mountain)." The same reasoning applies to Ptolemy's Geography 4.5.15, C

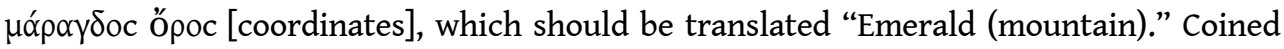
by modern scholars, the toponym "Mons Smaragdus" is an incorrect construction. ${ }^{28}$

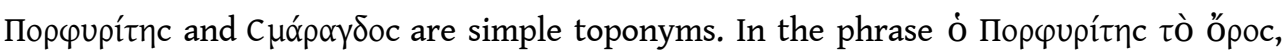
ópoc is just an apposition, not the generic element of a complex toponym.

Here is the passage, which is not necessarily free of corruption, where Ptolemy mentions the Porphyrites (Geogr. 4.5.27).

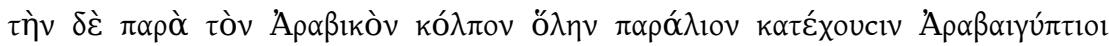

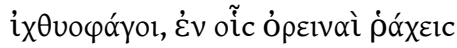

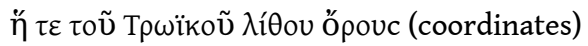

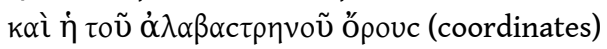

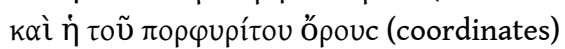

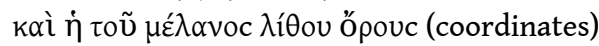

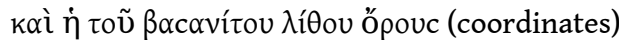

"The entire coastline along the Arabian Gulf is inhabited by Arabegyptian fisheaters, in whose territory are mountainous massifs: the massif of the mountain of Trojan stone (...); the one of the mountain of alabaster (...); the one of the mountain of porphyry (...); the one of the mountain of black stone (...); the one of the mountain of bekhen stone (....)."

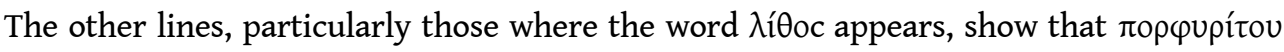
is here the name of the material, not the specific element of a complex toponym of which

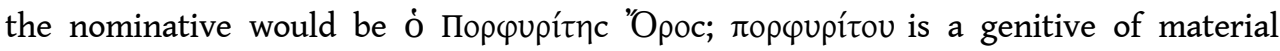
qualifying toũ ópouc. So we translate this line: "the (mountain range [’́óxıc]) of the porphyry mountain."

In Palladius, however, it is difficult to deny the existence of an abnormal phrase of which

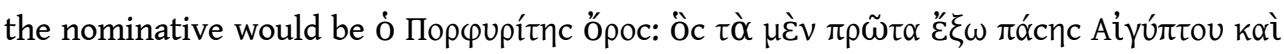

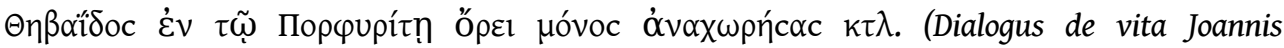
Chrysostomi, ed. Sources Chrétiennes 341, XVII 82). Nevertheless, this formulation is 
incorrect. Several explanations can be proposed, among which it is difficult to make a choice:

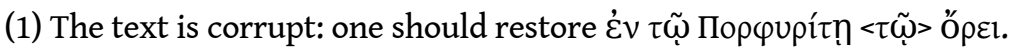

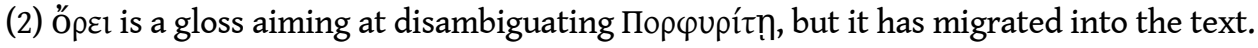

(3) As a neuter and masculine item has the same form in the dative, it was perhaps less

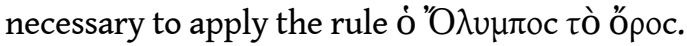

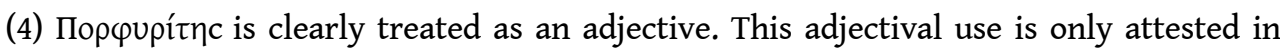

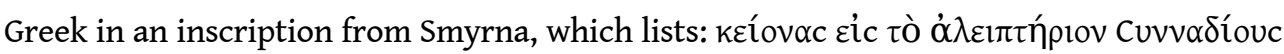

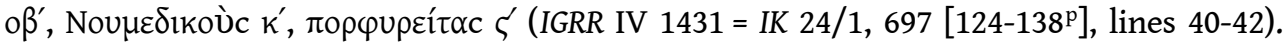
But at least this masculine word qualifies a masculine noun, which is not the case with Palladius. I also noted an example in Latin, where the noun (if the reconstruction l]agonam is correct) is feminine: ${ }^{29}$ ]agonam/porphyriten/cum basi d(e) s(uo) d(edit) (CIL XIII

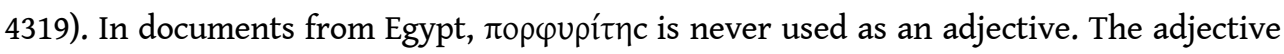

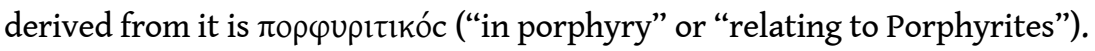

\section{Toponyms from materials. A pearl fishery in the Red Sea} material to place name, in the dedication of a Paneion situated in another metallon, in Wadi Umm Wikala (I.Pan 51 [AD 11]). This inscription, seven years prior to the discovery of Porphyrites, offers a series of placenames drawn from materials which has not been

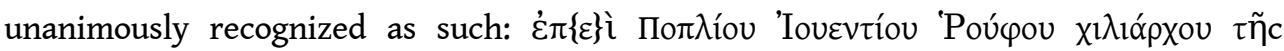

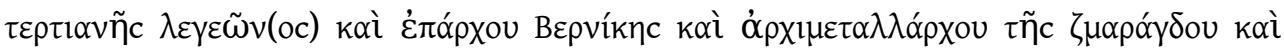

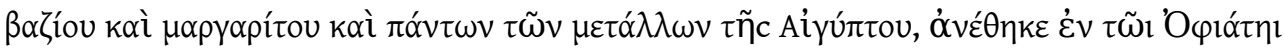

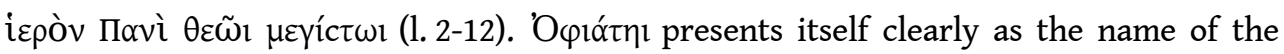
place and it is, as in the case of Porphyrites, a direct borrowing from the extracted

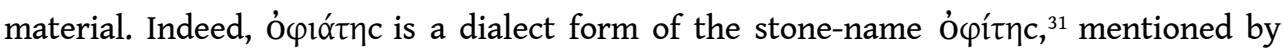
Pliny (Nat. 36.55): Pliny explains the difference between Augusteum and Tibereum, discovered in Egypt under Augustus and Tiberius, and ophite, the source of which he does not indicate, but it is likely the "Theban ophite" coloured with small flecks, evoked by Lucan: parvis tinctus maculis Thebenus ophites (Pharsalia 9.714). The fact that the words

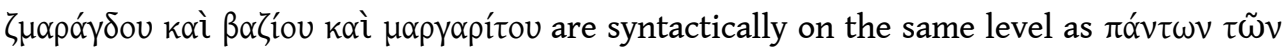
$\mu \varepsilon \tau \alpha \dot{\alpha} \lambda \lambda \omega v \tau \tilde{\eta} \mathrm{c}$ Aiүúrtou shows that these nouns are used as toponyms; so they should be

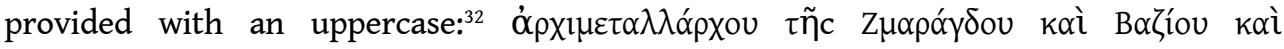

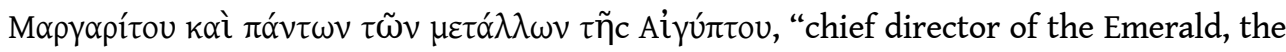
Topaz, the Pearl and all the mineral resources in Egypt." The same enumeration appears seven years later, in another inscription made by the same dedicant, Agathopous, freedman of the prefect Iuventius Rufus, engraved on a naos in the stone quarries of bekhen in Wadi al-Hammamat (I.Ko.Ko. 41 [AD 18]). 

identified, the location of Margarites is unknown. I agree with Dittenberger, who believes it to be somewhere in the Red Sea where conditions are favourable to the biology of pearl oysters. ${ }^{35}$ They are, in this region, Pinctada radiata and Pinctada margaritifera. According to G. Ranson, Pinctada radiata thrives in the tropics and a little beyond, in areas where freshwater inflows mitigate salinity. ${ }^{36}$ It would be plausible that the Romans had imposed an institutional framework on a fishery traditionally practised by a local population of Ichthyophagoi. Likewise, according to Strabo, in the early years of the Principate, the Smaragdos was exploited by Beduins whom he calls 'A $\alpha \beta \varepsilon c,{ }^{37}$ as it will be again in Late Antiquity by the Blemmyes..$^{38}$ Bahrain) ${ }^{39}$ are mentioned by ancient authors (but after the conquests of Alexander), the two dedications made by P. Iuventius Agathopous are the only ancient testimony to the possible presence of a pearl fishery in the Red Sea. Neither Pliny nor the Periplus Maris Erythraei say anything about it; and yet, the latter mentions the Persian Gulf fisheries, though outside the route described. ${ }^{40}$ We cannot exclude the possibility that the Margarites, operated by the State in the early years of the province, quickly found itself competing with foreign pearls, so that it would not have been considered worth the trouble to organise exploitation when Indian pearls and those from the Persian Gulf were flooding the market. But this operation may simply have left no written record other than the two early inscriptions of Agathopous, for shells of Pinctada radiata and Pinctada margaritifera were found in the excavations at Myos Hormos and Berenike, and the locals obviously liked to rework the shell. ${ }^{41}$ One would expect, however, in the case of a fishery, large shell dumps ${ }^{42}$-unless of course the fishermen threw them back into the sea. ${ }^{43}$ Such dumps do exist in the lagoon of Berenike, but local constraints (minefields) have not allowed archaeologists to go and look at the composition. ${ }^{44}$

The traditional interpretation of the name Margarites however has been challenged by Pierre Schneider:45 $\mu \alpha p \gamma \alpha \rho i ́$ inc, in the inscriptions of Agathopous might not be a pearl,

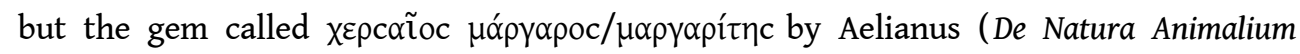
15.8.30) and by Origen (Commentarium in Evangelium Matthaei 10.7). These two sources place the "land-pearl" in India, a concept notoriously vague and which may include any region connected with Erythraean trade; Aelian curiously states that it has no inherent

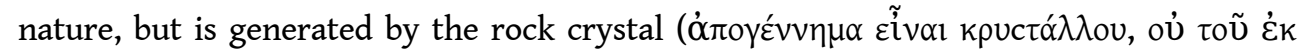

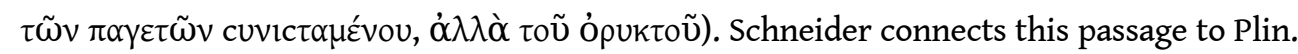
Nat. 37.23: citing Juba, Pliny reports that crystallum is found -among other sources- on the island in the Red Sea which also produces topaz, i.e. St John's Island. For Schneider,

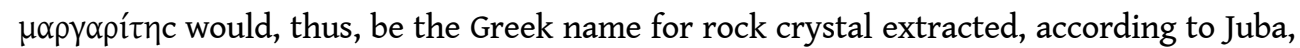

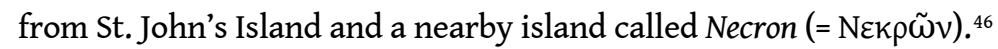

A final example of the name of the material used as a toponym (not to designate a metallon, but a latomia) is found in an archive of ostraca from Porphyrites, dating to late 3 rd $-4^{\text {th }}$ century. A number of these notes are orders to send bread to various microsites of

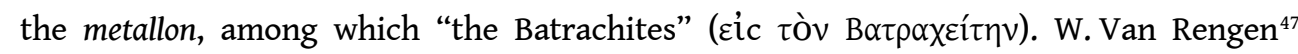
recalls in this respect a passage of Pliny, according to which "Koptos also exports batrachitai"; the naturalist distinguishes two types of these frog-coloured minerals. ${ }^{48}$ Is there a confusion with the batrachites later attested in Porphyrites? 


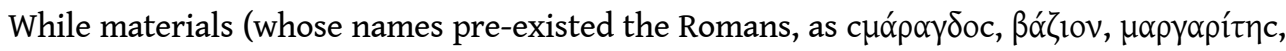

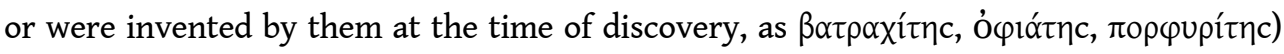
became place-names, conversely names of materials are derived from toponyms: the granite of Mons Claudianus was called marmor Claudianum, ${ }^{49}$ that of Tiberiane marmor Tibereum (Plin. Nat. 36.55).

\section{Metalla in the area of Umm Balad}

The number of occurrences of toponyms on ostraca is more or less inversely proportional to the distance between the named sites and the place of discovery. In other words, the more occurrences, the closer the site. See Table 4, where all the toponyms found on ostraca from Umm Balad appear, whatever the topographic feature.

\section{A. $\Delta$ outtıavń vs Kaıvì $\Lambda a T o \mu i a^{50}$}

The Umm Balad ostraca, excavated in 2002 and 2003, revealed several completely new names referring to metalla, wells and praesidia. Unfortunately, we do not know which sites they correspond to on the ground. There is even a slight uncertainty about the name of

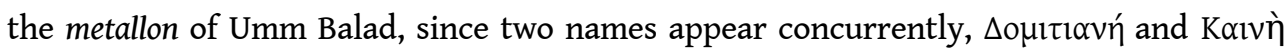
$\Lambda \alpha \tau o \mu$ ía. The most likely scenario is that the metallon was opened under Domitian

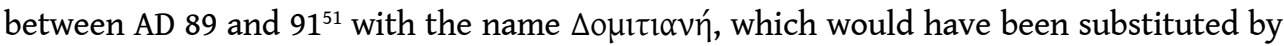
Kaıvทे $\Lambda \alpha \tau o \mu$ í $\alpha$ after the damnatio memoriae following the emperor's death (the specific Kaıvท́ almost certainly refers to the precedence of Porphyrites). However, analysis of the stratigraphy of the midden made by J.-P. Brun does not fit with this interpretation as

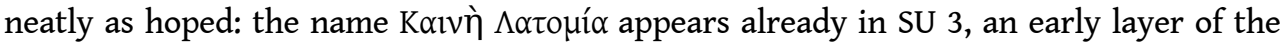

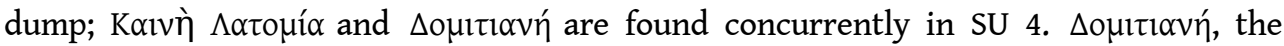
attestations of which are considerably fewer than those of Kaıv̀े $\Lambda \alpha \tau o \mu$ í $\alpha$, also appears in layers with Antonine material: residual material or survival of the name? To solve the problem, J.-P. Brun explains that, on the one hand, the $c$. eight years of works under Domitian must have left a very thin layer at the bottom of the dump and that, on the

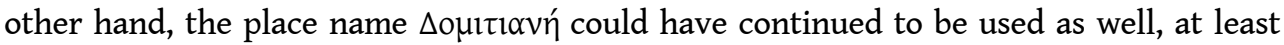
locally, despite its official replacement by a bland Kaıv̀े $\Lambda \alpha \tau o \mu i ́ \alpha$.

\section{B. Small metalla listed in the area of Umm Balad, orphan toponyms}

Besides Porphyrites and Claudianus, which we have treated above, the O.KaLa. mention two other metalla, Germanike Latomia and Alabarches. To identify their location we have three possible candidates ${ }^{52}$ which are all equally viable:

(1) The area formed by the two quarries and the workers' village ${ }^{53}$ located at the bottom of the wadi, access to which was controlled by the praesidium of Umm Balad; the distance between the fort and the extraction zone is, meandering along this wadi, c. $1.20 \mathrm{~km}$. Letters mentioning Alabarches suggest, without certainty, that it could be this site; Alabarches would, therefore, be a microtoponym within the metallon of Domitiane/Kaine Latomia.

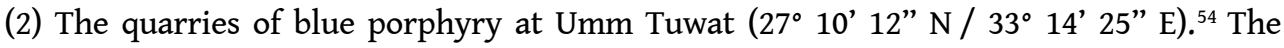
Romans extracted, in the first to second centuries, a blue-grey porphyry (trachyandesite porphyry $)^{55}$ which has stick-like inclusions reminding of the green porphyry from Sparta (Fig. 2). Umm Tuwat is c. $6 \mathrm{~km}$ as the crow flies northwest of Umm Balad (there is no 
direct route between the two sites, but we have not had time to check if there were mule tracks). The site comprises no agglomeration; ${ }^{56}$ Bagnall and Harrell only indicate three extraction points (Fig. 3) and two small buildings of $3.5 \mathrm{~m}^{2}$ and $5.5 \mathrm{~m}^{2}$. There are very few ceramics, but the wide and beautiful stone-free track that leads there suggests that the Romans had ambitions for this site (Fig. 4). It has been suggested that the blue porphyry of Umm Tuwat was the knekites, one of the materials listed by Tiberius Cominius Leugas, the discoverer of Porphyrites. ${ }^{57}$ Umm Tuwat porphyry was spotted in the palaces of the Palatine, but objects made of this material are extremely rare; the main one is the right column at the entry of the chapel of St. Zenon at St. Praxedes (fig 5). ${ }^{58} \mathrm{Kv \eta \kappa ít \eta c} \mathrm{is} \mathrm{derived}$ from кvп̃ кос, "saffron," Carthamus tinctorius, which, used as a dye plant, produces yellow. Indeed, the porphyry of Umm Tuwat has no yellow in it, but if one accepts the idea that the ancients perceived colours more in terms of their light intensity than their hue, knekites could mean "pale stone" and, of all the materials extracted in the Eastern Desert, only the porphyry of Umm Tuwat could, according to the authors of this hypothesis, fit that description.

Fig. 2

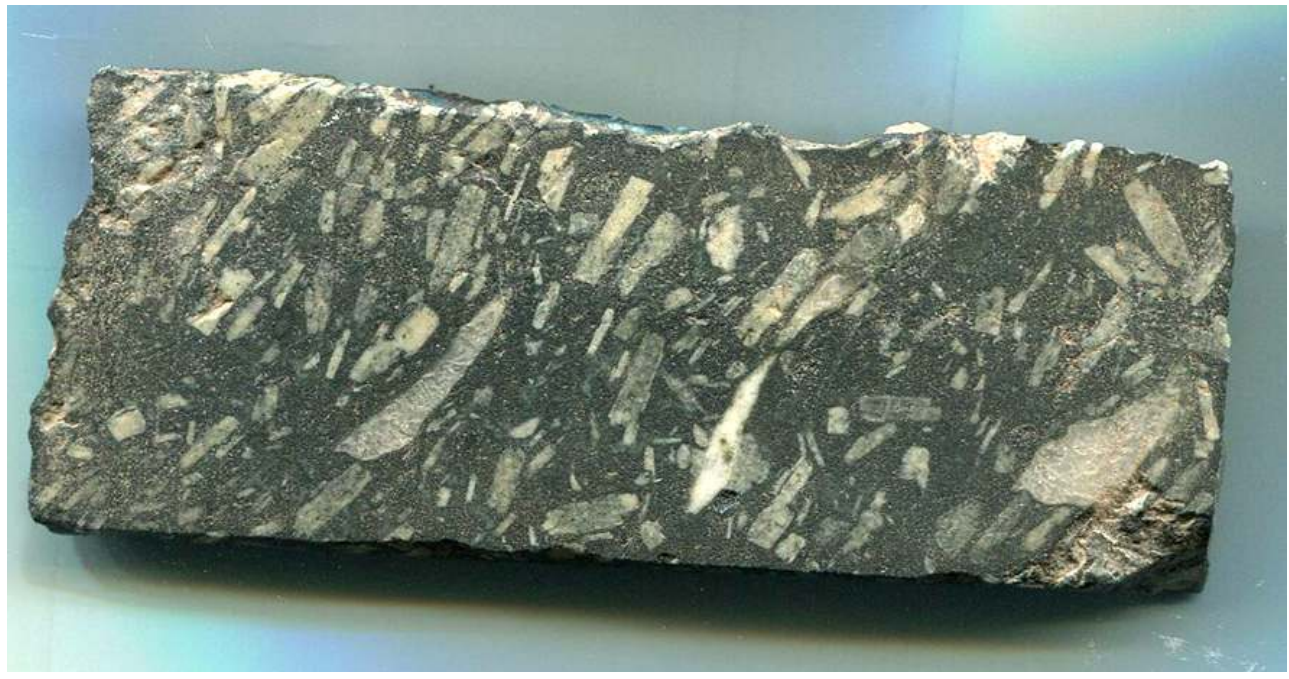

A porphyry plate from Umm Tuwat polished on one side, found in the midden at Umm Balad.

(c) All rights reserved 
Fig. 3

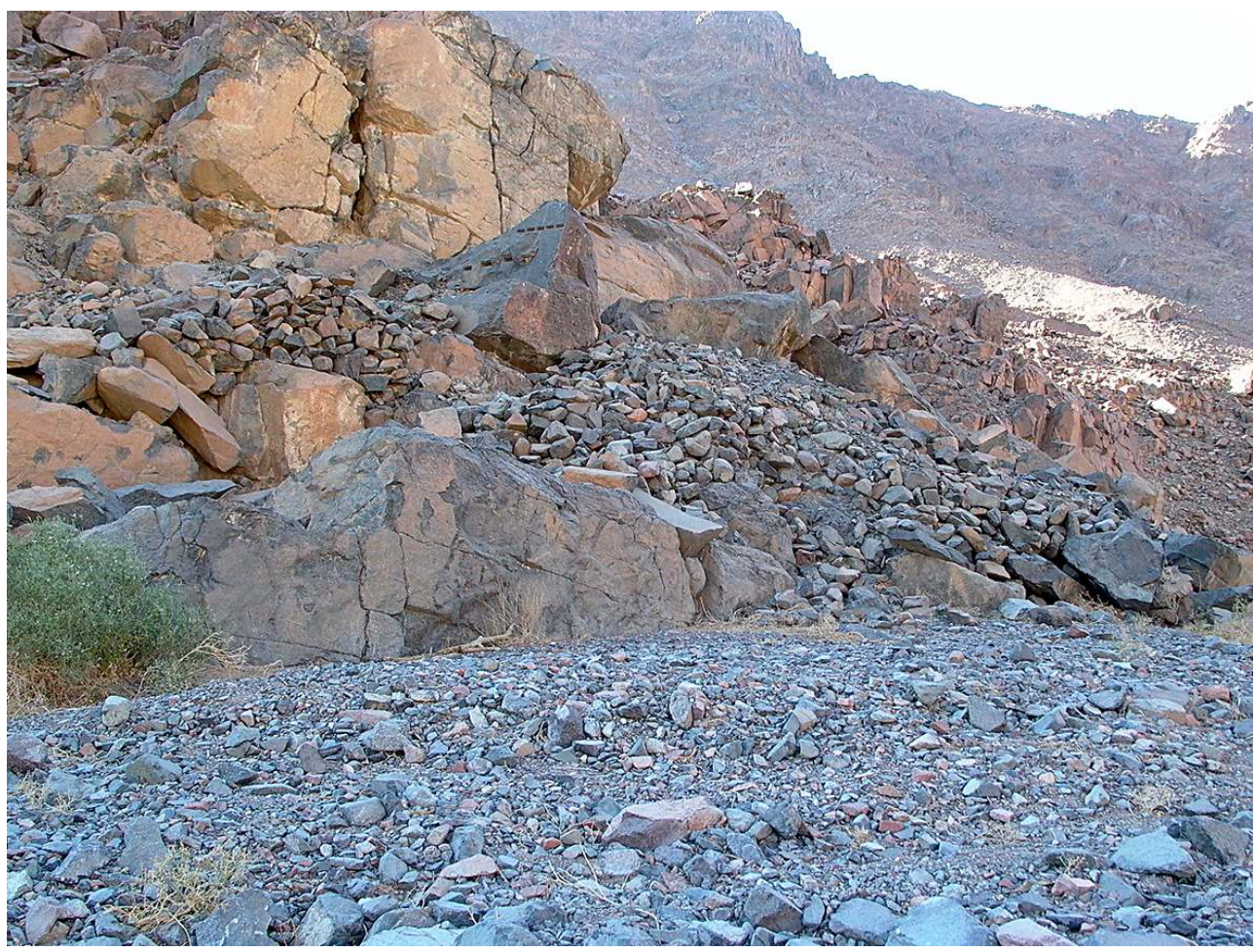

A latomia at Umm Tuwat.

(c) Adam Bülow-Jacobsen 
Fig. 4

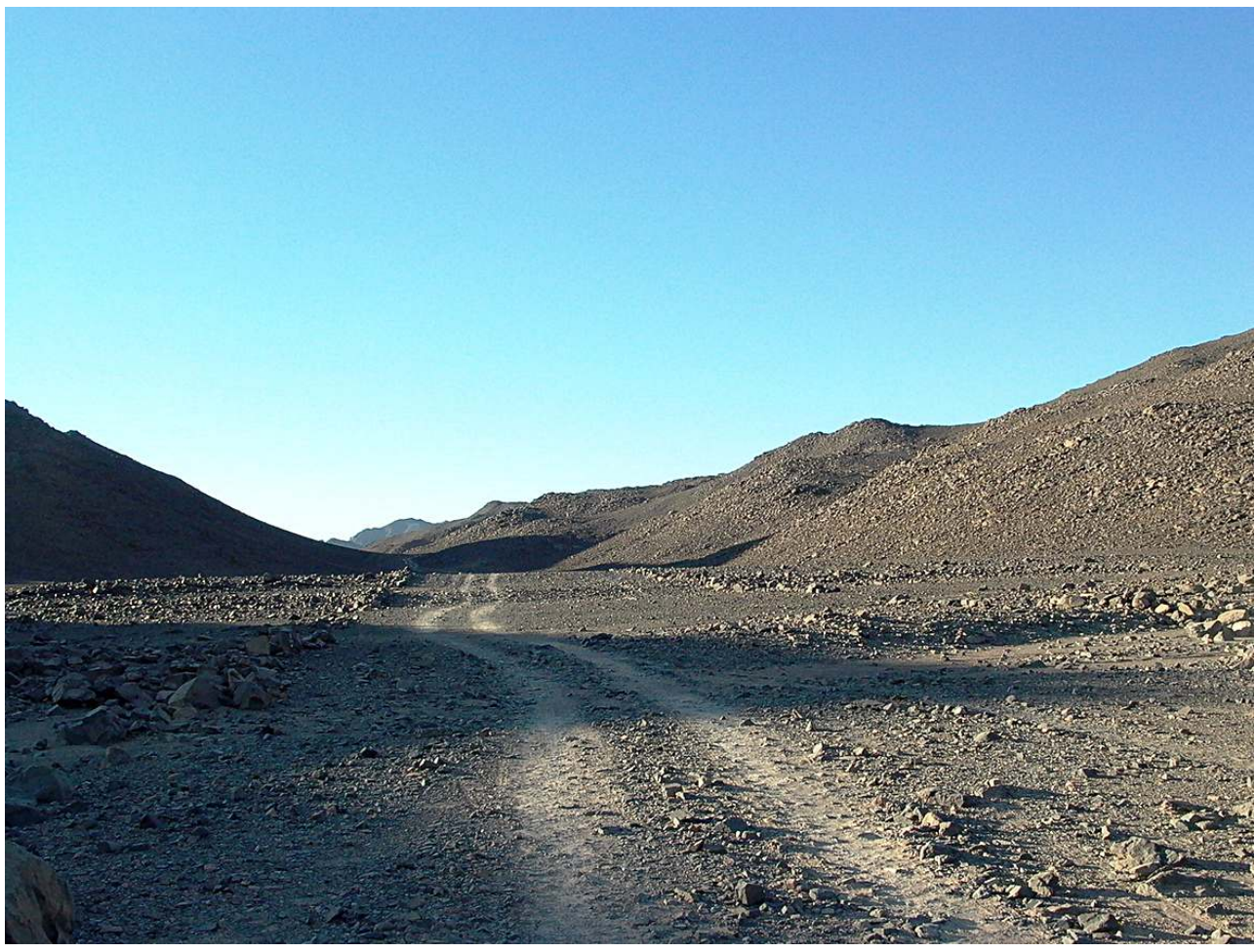

The track towards Umm Tuwat.

(c) Adam Bülow-Jacobsen 
Fig. 5

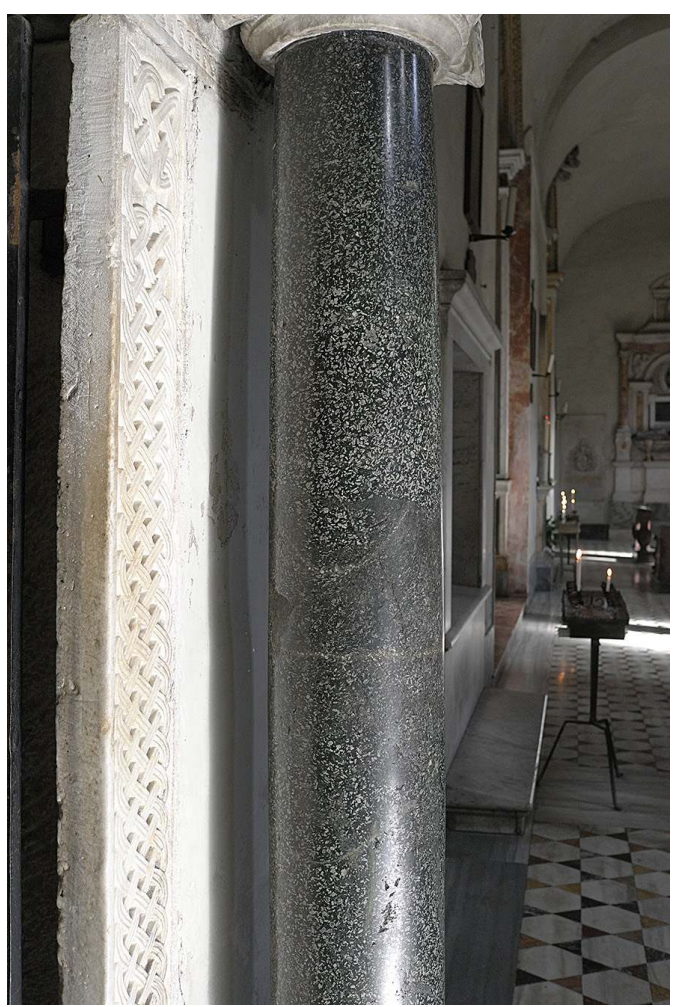

PORPHYRY COLUMN FROM UMM TUWAT IN ZENON'S CHAPEL AT ST. PRAXEDES.

(C) ADAM BÜLOW-JACOBSEN

(3) The diorite quarry of Umm Shejilat ${ }^{59}$ which is $c .18 \mathrm{~km}$, almost in a straight line, south of the praesidium of Qattar, was quarried during the first/second century AD. ${ }^{60}$ We did not go there, but the satellite image shows access to it from Qattar. The built-up area is not shaped like a praesidium. Mons Claudianus is not far away, but the mountainous terrain prevents direct communications between the two sites. Umm Shejilat had to be in the orbit of Porphyrites and perhaps more precisely of Umm Balad. However, caravans carrying provisions must have come from Kaine and left the hodos Porphyritou at the small station of Bab al-Mukhaniq, from where Meredith's map shows a road leading to the gold mine of Wadi Ghazza and to an anonymous granite quarry which corresponds, according to its location, to Umm Shejilat (Fig. 6). 
Fig. 6

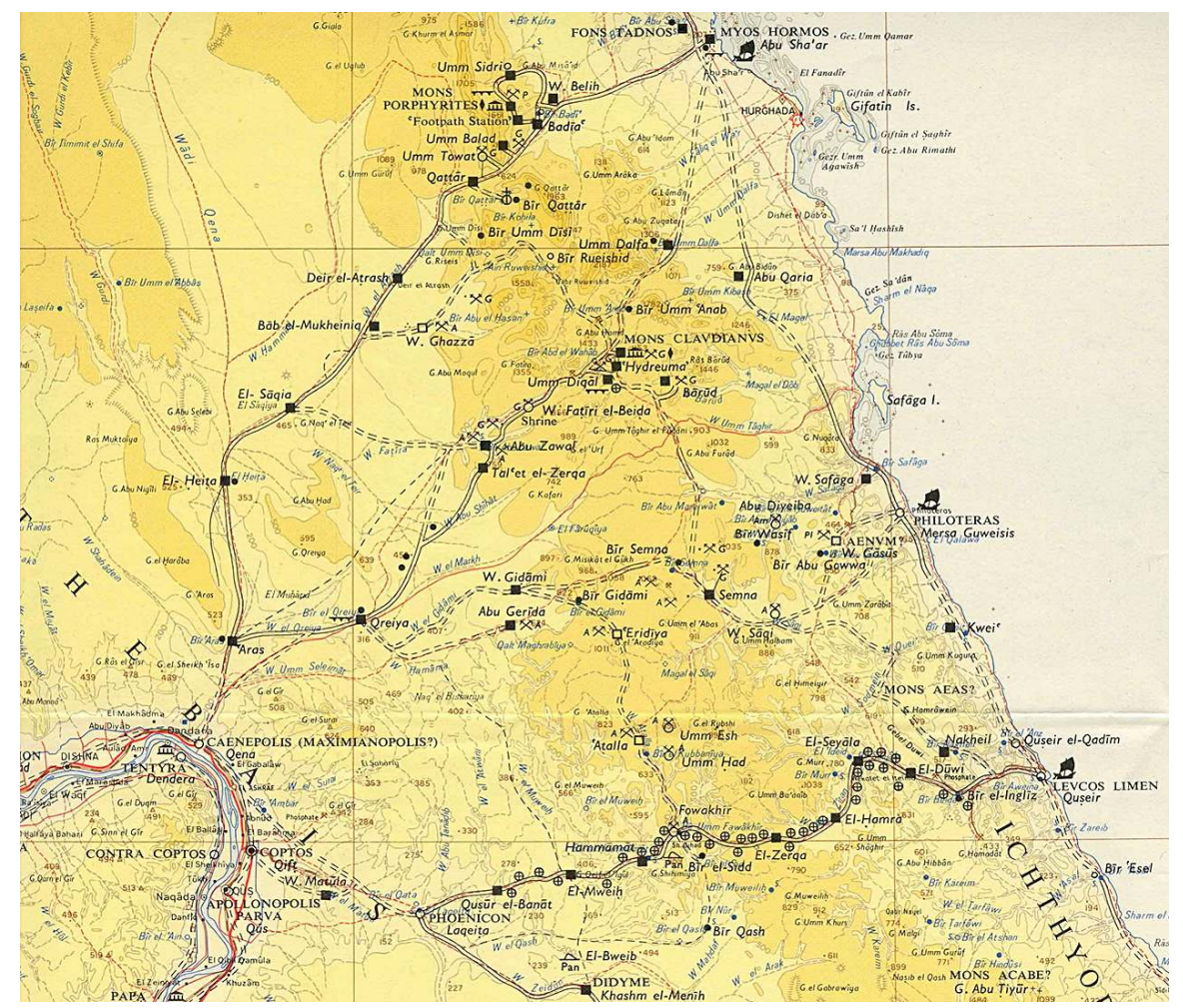

Map of the Tabula imperii romani, Sheet Coptos published by Meredith 1958.

(c) ALL RIgHTS RESERVED

The name of this metallon appears only in O.KaLa. inv. 765, a receipt issued by a sklerourgos

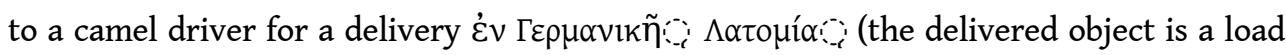
and a half of monthly rations for quarry workers). ${ }^{61}$ The document is dated $2^{\text {nd }}$ Phaophi of Domitian's $16^{\text {th }}$ regnal year, or $29^{\text {th }}$ September AD 96 (the news of the Emperor's death,

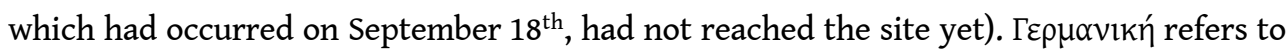
the cognomen ex virtute Germanicus, to which Domitian was very attached, and shows that the metallon had been opened under this emperor, in the same way as $\Delta$ ouıtıaví. The Germanike Quarry should not be very far from Umm Balad, as the camel driver, who had probably loaded his animals at Umm Balad, had brought back the receipt as proof. This could be Umm Tuwat. The fact that two pieces of porphyry from Umm Tuwat were found in the midden at Umm Balad (one was polished, Fig. 2) shows that in any case the two metalla worked at the same time, that is to say under Domitian and/or Trajan. Isolated and poorly equipped, Umm Tuwat probably depended for its supplies on Umm Balad.

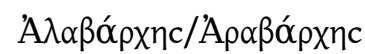

This name is attested in seven ostraca from Umm Balad, six private letters, which are rather uninformative and an amphoric titulus published below (Fig. 7). Only the latter suggests that Alabarches/ Arabarches $^{62}$ must have been a metallon. The amphora belonged to the architect Sokrates. Does the place-name refer to an arabarches ${ }^{63}$ or an individual called Arabarches, since this title was used -especially in Thebes and Elephantine- as a personal name ${ }^{64}$ Since the question of customs duties is probably 
irrelevant in this part of the Eastern Desert, I am inclined to favour the second hypothesis, and to relate Arabarches to the anthropophoric names of some latomiai at Mons Claudianus. The choice of a personal name may reflect the fact that Arabarches was a small metallon. For A. Bülow-Jacobsen, it could be the workers' village at the foot of the quarries of Umm Balad (see § 34 [1]).

O.KaLa. inv. 269 (Fig. 7) Domitien/Trajan

Umm Balad, phase A - US 2 (3208) $\quad 10.5 \times 3.5 \mathrm{~cm} \quad$ Nile silt clay

Titulus on amphora AE3.

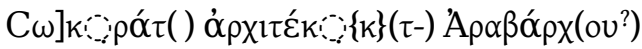

$$
\begin{aligned}
& \text { ]. .[ }
\end{aligned}
$$

Sokrates, architect at Arabarches.

1. The absence of a preposition dictates the restoration of the genitive. This is the only case in the ostraca from the metalla, where the trade-name $\dot{\alpha} \rho x \imath \tau \varepsilon \kappa \tau \omega v$ is determined by a place name.

Fig. 7

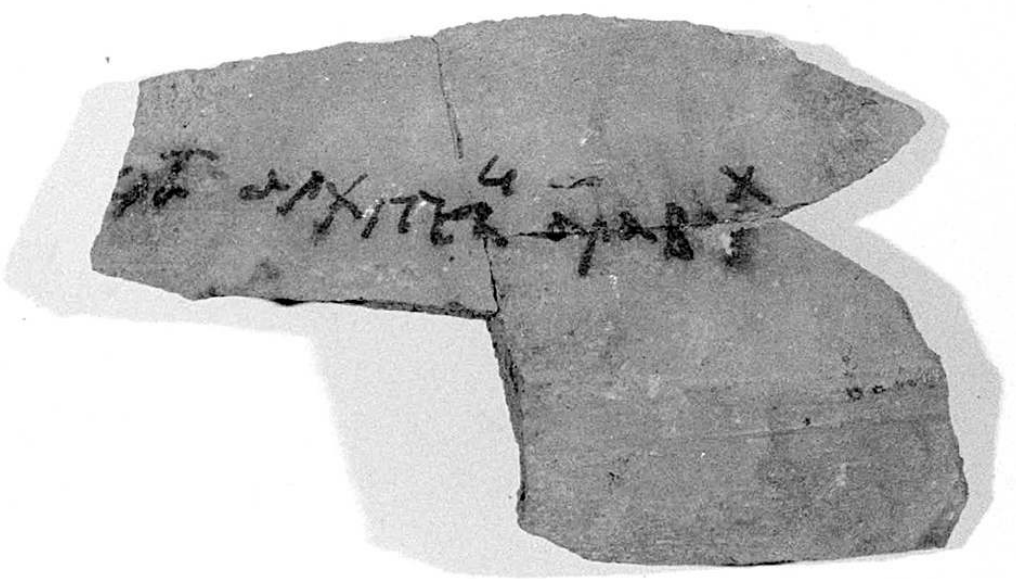

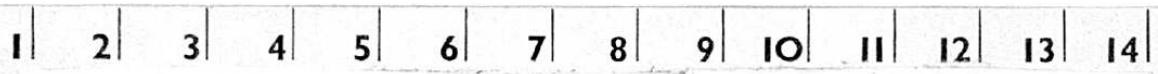

$$
\begin{aligned}
& \text { Umm Balad 2001/2. AB.J. INV. } 269
\end{aligned}
$$

O.KALA. INV. 269.

(C) A. BÜLOW-JACOBSEN

A $\lambda \alpha \beta$ ó $\rho x \eta c$ is most often used without an article, ${ }^{65}$ but the paucity of occurrences does not allow us to make it a general rule: in the epistolary ostraca from Umm Balad,

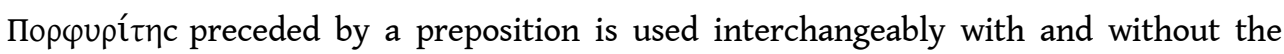

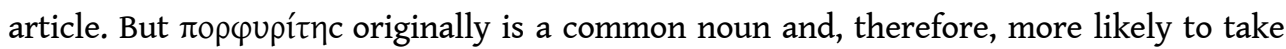
the article, while A $\lambda \alpha \beta \alpha$ oxp $c$, as we have seen, may be an anthroponym.

\section{Latomiai: quarry names of Mons Claudianus}

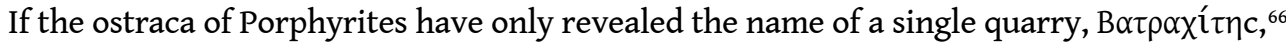
the Claudianus corpus has yielded a rich harvest of these microtoponyms. I have taken 
almost all of them from O.Claud. IV. The infrared photos that A. Bülow-Jacobsen took after publication of the book allowed me to make some corrections. In the inventory below, I only quote the instances that allow us to observe the morphological and syntactic behaviour of these names.

of the 130 quarries reported by David Peacock, only seven, the names of which are known from the ostraca, were identified through inscriptions found on the spot: Epikomos, Harpocrates, Hieronymus?, Kochlax, Myrismos, Nikotychai, Philok(). I indicate, in this case, the number given by David Peacock. ${ }^{67}$

\section{Inventory}

42 'A $\mu \mu \omega v^{?}$ (Antoninus?)

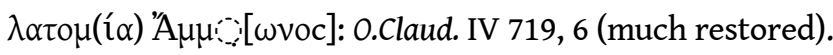

$43 \quad$ 'Avoußic (Trajan)

This quarry is mentioned once in the opening words of a list of experts in the form Avoú $\beta_{1}$ (O.Claud. IV 632, 1). Although both lines of this incipit pose insuperable difficulties in reading and interpretation, I think that this is the dative Avoú $\beta$, well-attested in the inscriptions (there are many examples outside Egypt, especially in Delos; in Egypt: I.Alex.impér. 124).

44 'A $\pi \mathrm{lc}$ (Trajan)

Mentioned in the dative "A $\pi 1 \delta 1$ with other names of quarries and of other features that are allocated water rations in the large organisational chart O.Claud. inv. 1538, 2 and 6 (Cuvigny 2005).

45 Aлó $\lambda \lambda \omega v$ (Trajan)

Six certain occurences. Probably a different quarry to Apollon Epikomos, only called Epikomos in the ostraca.

- A] Ó $\lambda \lambda \omega v$ oc: O.Claud. inv. $2853,5{ }^{68}$ In this catalogue of water distribution, quarry names are in the nominative when they are adjectives, and in the genitive when they are theonyms or anthroponyms.

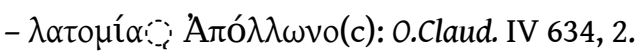

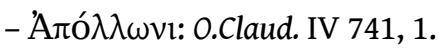

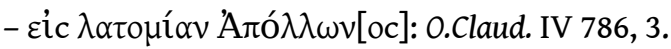

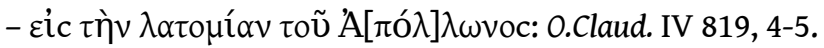

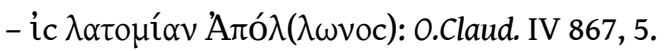

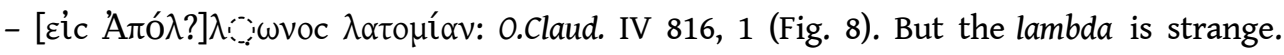

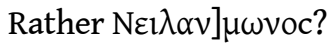


Fig. 8

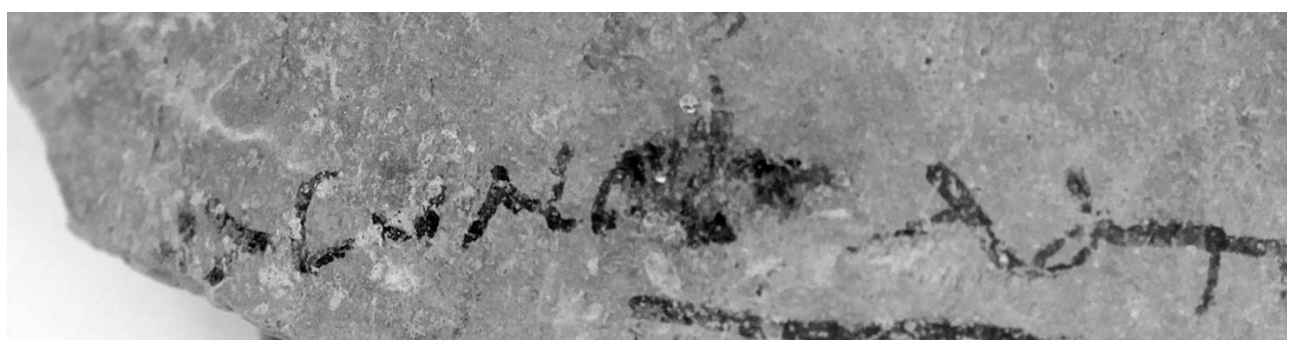

O.CLAUD. IV 816, 1 (DETAIL).

(C) ADAM BÜLOW-JACOBSEN

In O.Claud. IV 866, 4, the infrared image shows that A $\pi_{0} \lambda \lambda \omega v$ ou was corrected by the scribe into Ađó $\lambda \lambda \omega v o c$, a sigma having been written in the line space above the upsilon (Fig. 9). Given the context, it seems certain that this is a city, not a quarry, and that we

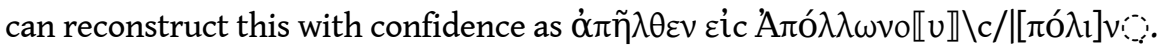

Fig. 9

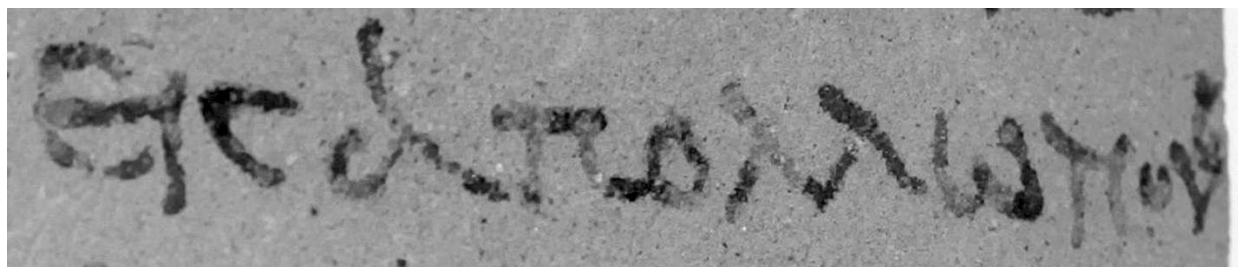

O.CLAUD. IV 866, 4 (DETAIL).

(C) ADAM BÜLOW-JACOBSEN

47 Aртокра́тпс (Trajan and Antoninus)

The Harpocrates quarry is marked with a Latin inscription, where its name is preceded by the mark CEP, suggesting it was part of the caesura of Epaphroditos ${ }^{69}$ (= Peacock No. 109; cf. Peacock, Maxfield 1992 p. 188 and 220). This latomia is attested in three ostraca only:

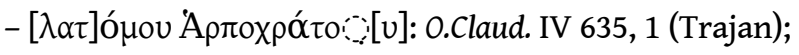

- Arpochrate: O.Claud. IV 843, 6 (Trajan?);

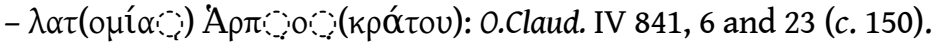

Aủyoúctn (Trajan)

Aủyo(úcṭ̂): 0.Claud. IV 775, 8 and 776, 11.

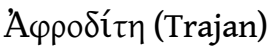

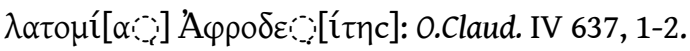

Bóp $\beta \alpha \rho o c$ (end of the reign of Hadrian)

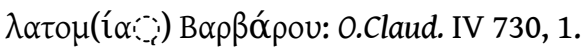

$51 \quad \Delta$ lóvucoc (Trajan and Antoninus)

A dozen instances, including:

- $\Delta$ lovúcw: O.Claud. IV 699, 15.

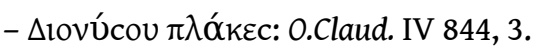

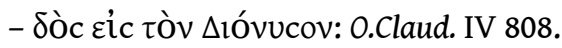




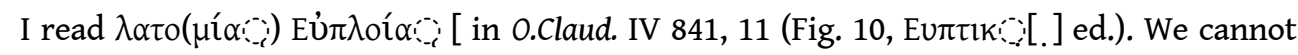
exclude Eủ $\pi \lambda \lambda_{o} \alpha[c]$, but it should be noted that the text presents two certain examples of

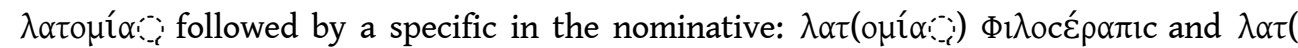
opía (-i) Kóx $\lambda \alpha \xi$. The quarry-name "Good navigation" is not irrelevant, since the monoliths extracted came down the Nile and across the Mediterranean.

Fig. 10

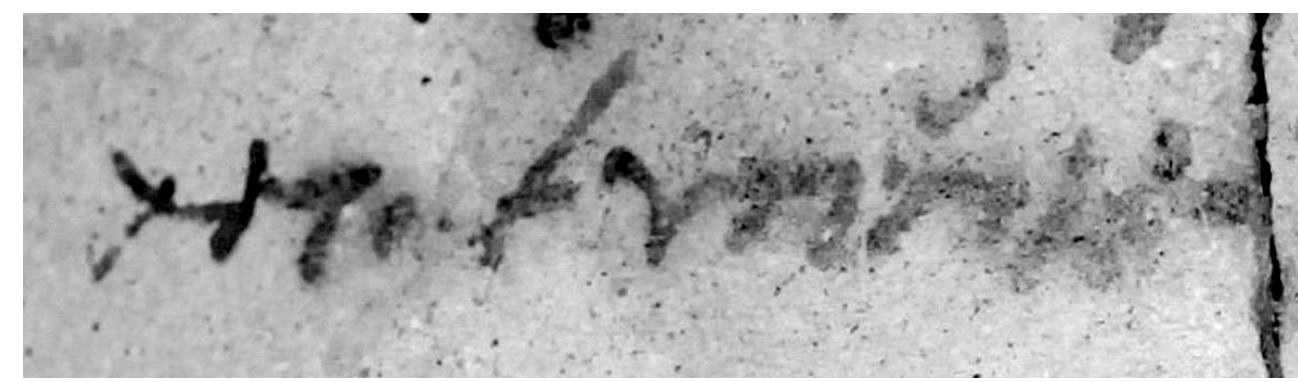

O.CLAUD. IV 841, 11 (DETAIL).

(C) ADAM BÜLOW-JACOBSEN

Eight occurences, all in the dative and without the generic. This is the anthroponym

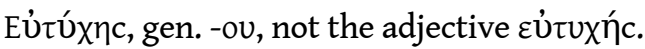

Zevoc (Trajan)

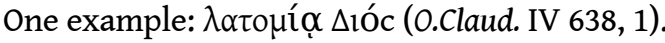

"Hpa (Trajan)

The quarry of Hera appears in several listings of quarries in the dative ("Hpô) and in the genitive "Hpac (depending on an implied $\lambda \alpha \tau o \mu$ í $\alpha$ ) which serves as a header in the list of

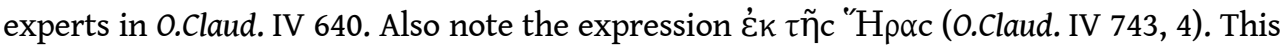

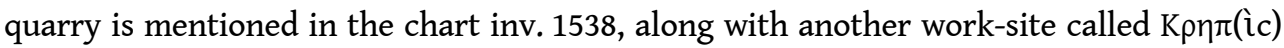


"Hpac, perhaps the platform to allow the loading of the blocks extracted from the Hera quarry onto chariots (on krepides, see § 104).

'I $\rho \omega \omega v v \mu o c$ (Trajan)

This name from a family of architects appears twice in a quarry name, as the modifier of a

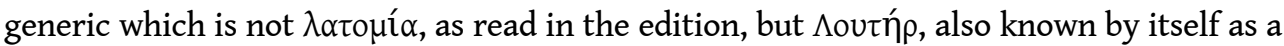
quarry name.

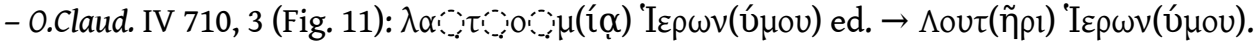

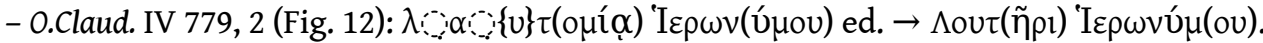

Fig. 11

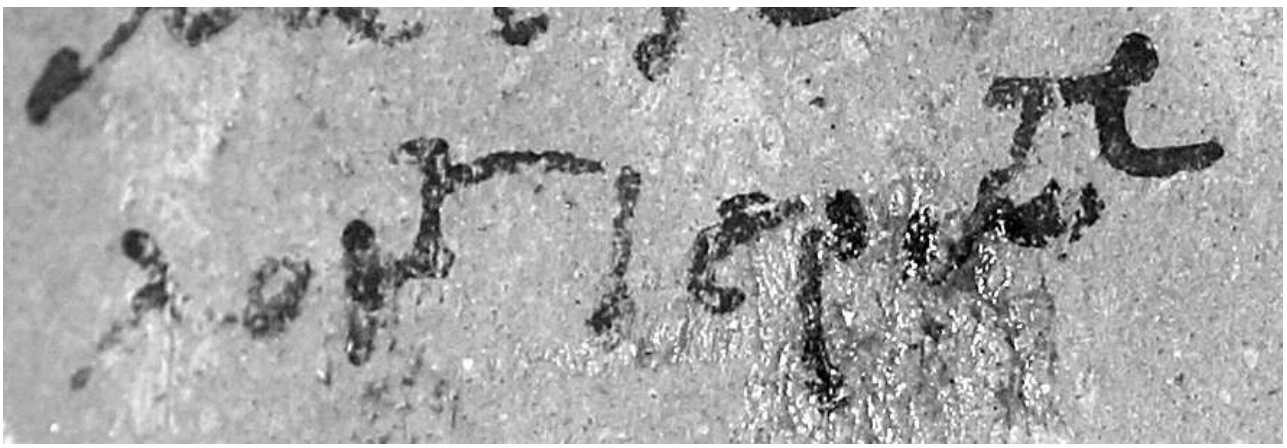

O.Claud. IV 710, 3 (detail).

(c) ADAM BÜLOW-JACOBSEN

Fig. 12

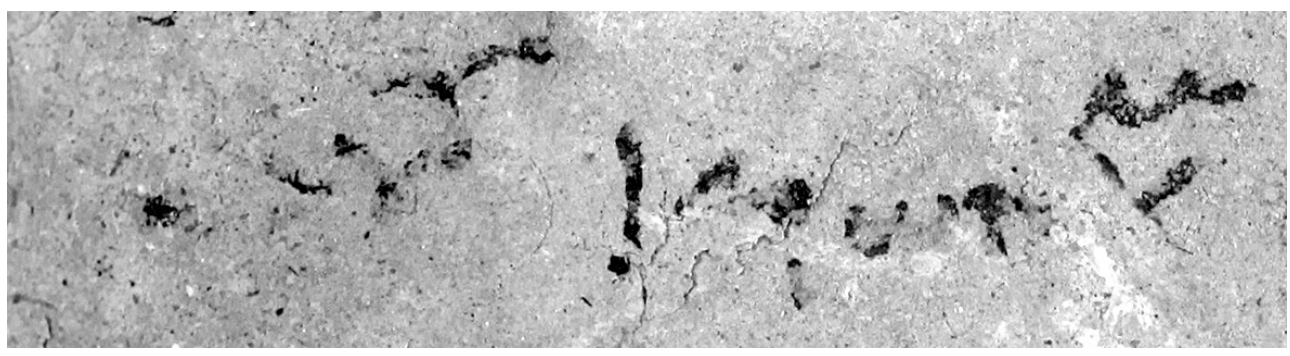

O.Claud. IV 779, 2 (detail).

(C) ADAM BÜLOW-JACOBSEN

To these two instances, one should add the Latin account O.Claud. IV 843, where the quarry is simply called Hieronymi. It is impossible to establish with certainty whether

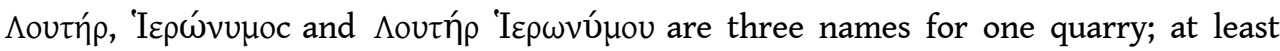

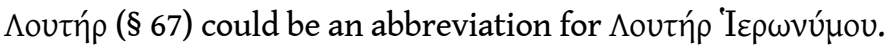

Hieronymos may be identified with quarry No. 83, north of the cemetery: on one side the letters $1 \varepsilon \rho \omega$ are engraved (Peacock, Maxfield 1997, p. 187 et Fig. $6.57=$ SEG XLII 1575). This case of an architect eponymous of a quarry is unique. The name of the architect Herakleides appears on a quarry face in quarry No. 129 , but preceded by $\delta 1^{\prime} .^{72}$

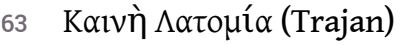

The namesake of the metallon at Umm Balad, it is attested among other latomiai names in four related lists of quarry names (O.Claud IV 700 and comm ad. 2; 702; 704; 777). 
Five examples, including:

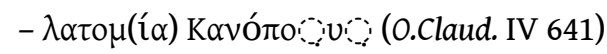

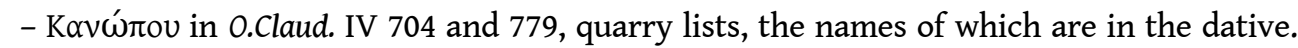
In these lists, anthropophoric quarry names are usually in the dative even if they are known elsewhere as $\lambda \alpha \tau o \mu i ́ \alpha+$ anthroponym in the genitive. However, I think we can read

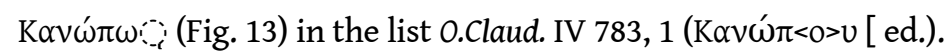

Fig. 13

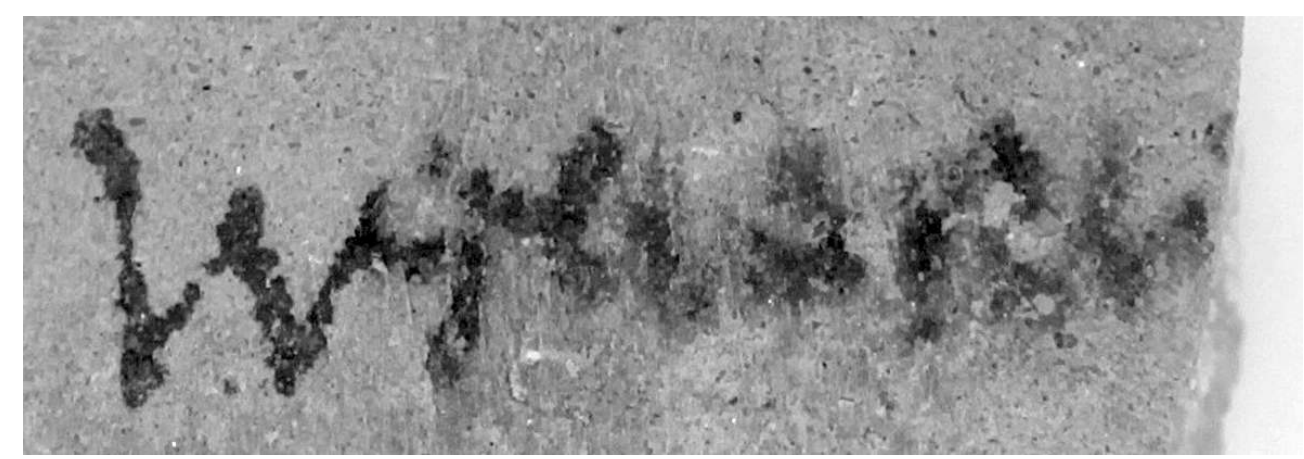

0.Claud. IV 783, 1 (detail).

(c) ADAM BÜLOW-JACOBSEN

Kóх $\lambda \alpha \xi$ (Antoninus)

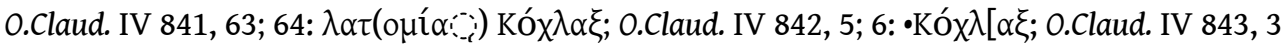
(Trajan?): Cochlax. Kóх $\lambda \alpha \xi$ never inflects; this rare and onomatopoeic word means "gravel." The Kochlax quarry, identified by an inscription with this name, is No. 120 in the inventory of D. Peacock.

$\Lambda \varepsilon ́ \omega v$ (Trajan and c. AD 150)

The quarry is simply called $\Lambda$ Éovıı in several lists of quarry names in the dative, but $\lambda \alpha$

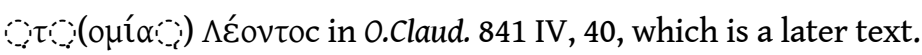

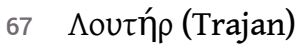

Five ostraca mention this quarry, which seems to take its name from the object, bath or basin, that was being (had been?) extracted.

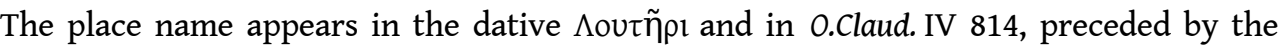

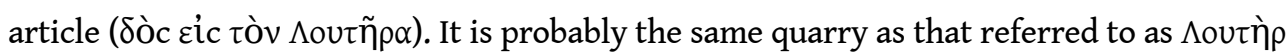

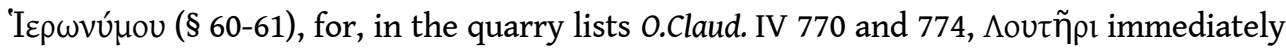
precedes Mécn, while in two lists pertaining to another series, O.Claud. IV 710 and 779, Mé

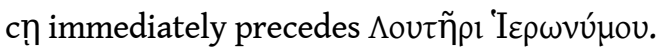

69 Móp $\omega \omega v$ (Trajan and c. AD 150)

As for the Leon quarry, the anthroponym refers to the quarry itself and not, as it seems, to a person with a relationship to it: many occurrences of Móp $\omega v \mathrm{v}$ appear in lists of quarry names in the dative, but this feature was forgotten in the time of O.Claud. IV 841,

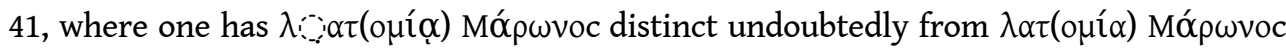

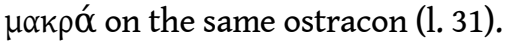

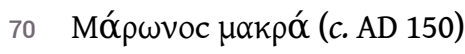

The "long quarry of Maron" is only attested in O.Claud. IV 841, 31. The edition gives the 
impression that it belonged to the caesura of Epaphroditos, which appears as a header to a text block on line 30. This is curious, given that Maron's quarry is in the caesura of Enkolpios according to 0. Claud. IV 841, 41. However, the infrared image shows that $\kappa o \pi(\tilde{\eta}$ (i) $)^{\prime} \operatorname{E} \alpha \varphi \rho \circ \delta(i ́ \tau o v)$ on line 30 is intentionally deleted ${ }^{73}$ (Fig. 14).

Fig. 14

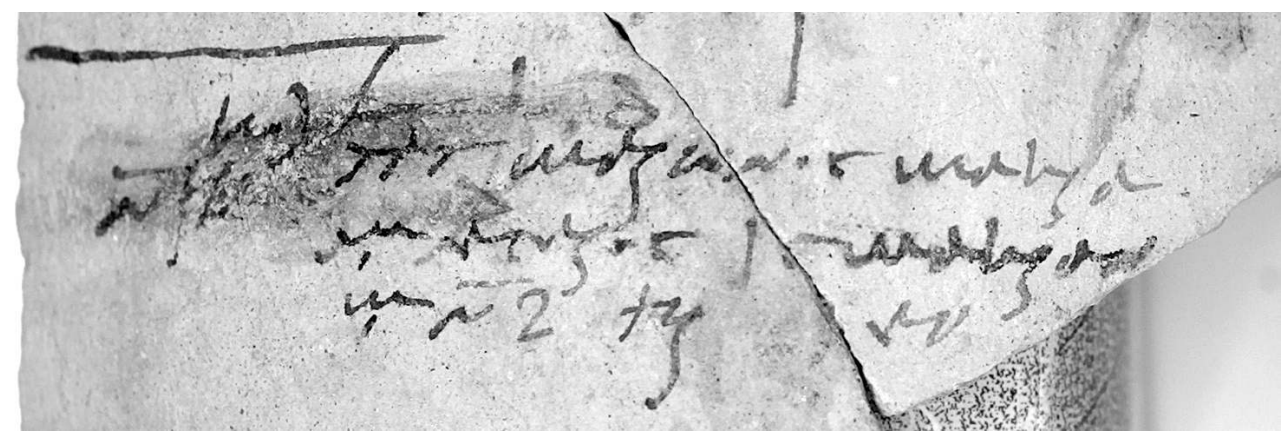

O.Claud. IV 841, 30-33

(C) ADAM BÜLOW-JACOBSEN

Mzүó $\lambda \eta \lambda \alpha \tau o \mu i ́ \alpha$ (Trajan and c. AD 150)

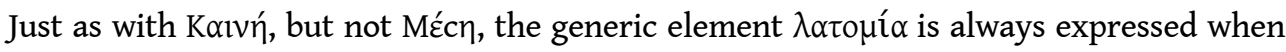
qualified by Mعүá $\lambda \eta$ (see 0.Claud. IV 782, 2-3). Two occurrences under Trajan, then in o.Claud. $841 \mathrm{IV}, 65$.

MÉcn (Trajan and c. AD 150)

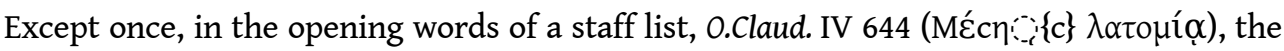
"Middle" quarry, frequently mentioned, is referred to simply as MÉc

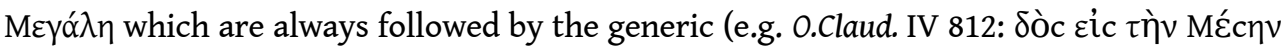

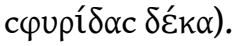

The later account 0. Claud. IV 841, 54 suggests that this important quarry could have been

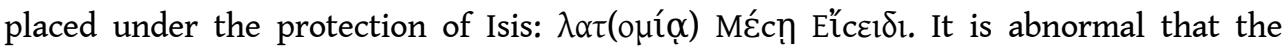
theonym after $\lambda \alpha \tau$ to ía is not in the genitive.

74 Mí日pac (Trajan)

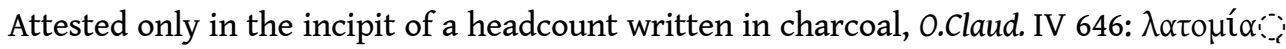
Mí $\theta \rho \alpha$. Other examples of $\lambda \alpha \tau o \mu$ í $\alpha$ name of god in the genitive suggest the interpretation of $\mathrm{M} i^{\prime} \theta \rho \alpha$ as a genitive, not as a dative in apposition.

Mupicuóc (Trajan [and Antoninus Pius?])

The four certain examples of the Myrismos quarry (Peacock No. 22) date to Trajan. The quarry could have functioned under Antoninus Pius if we accept the reading ex lat(omia) Mur. in the Latin account O.Claud. IV 845. The name of this quarry appears in three ostraca abbreviated as $\operatorname{Mvpic\mu }()$. It is preceded by the generic in the inscription that we found in the rubble of the quarry, after its destruction by the Zamzam Company in 1989 (Fig. 15). Jean Bingen published the Greek text of the inscription and translated it "The (column)

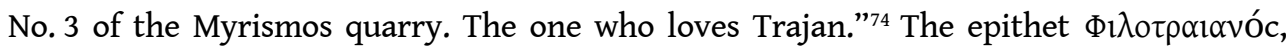
because it is in the nominative, cannot be a second name of the $\lambda \alpha \tau o \mu$ ía, hence Bingen's

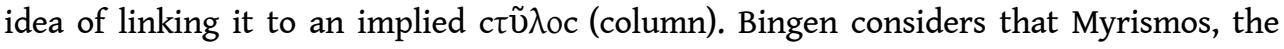
eponym of the quarry, is "perhaps an imperial slave or a Greek contractor." 
Fig. 15

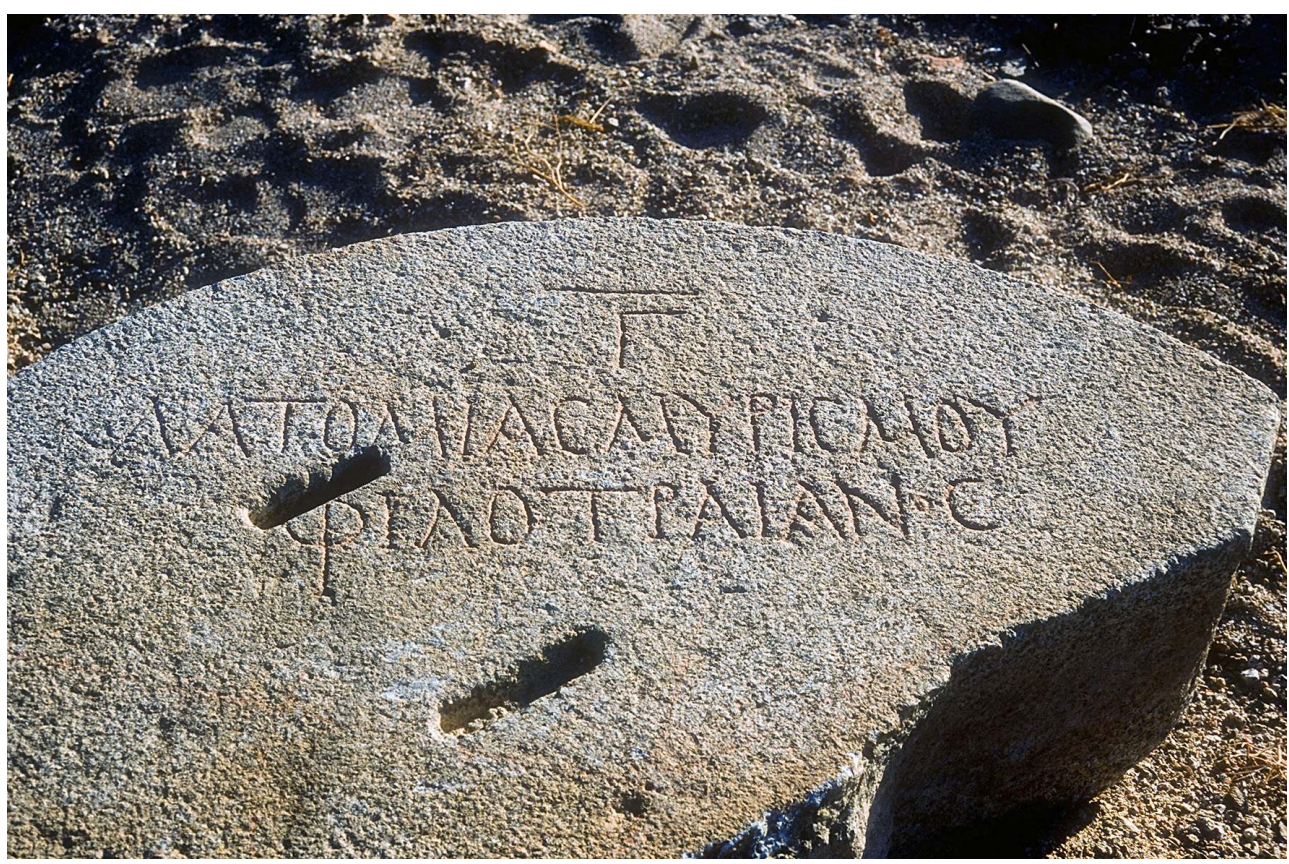

Column base inscribed on the underside, from the quarry of Myrismos.

(C) ADAM BÜLOW-JACOBSEN

$76 \mathrm{~N} \varepsilon \lambda \lambda \alpha ́ \alpha \mu \omega \nu$ (Trajan or Hadrian)

This quarry is mentioned in only five headcounts written by the same scribe, who invariably expresses the generic and dissimilates the first $\mu$ to $v: \lambda \alpha \tau o \mu i \alpha_{1} N(\varepsilon) \imath \lambda \alpha{ }^{\prime} \nu \mu \omega v o c$ (0.Claud. IV 734-738). This spelling can be explained as a fault of hypercorrection and, perhaps, through the novelty of this polytheophoric personal name, which does not spread in the papyri before the end of the second century AD (the oldest example, P.Oxy. III 477, is dated to AD 132/133). We should not completely rule out the existence of a Neilammon god, perhaps attested in the temple inventory P.Erl. 21, 32 (prov. Unknown, c.

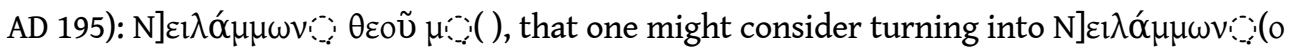
c) $\theta \varepsilon \circ \tilde{v} \mu(\varepsilon \gamma$ íctov).

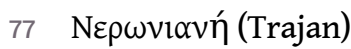

Two instances, $\lambda \alpha \tau$ นuí $\alpha$ always being implied (O.Claud. IV 776, 16; 777, 2). There is also the beginning of this toponym, but erased, in O.Claud. IV 841, 41, of c. AD 150.

78 Nikotú $\chi \propto l^{75}$ (Trajan)

The name of this quarry is inscribed scriptio plena on a granite bed that was cleared of overburden, but which was not worked (Fig. 16, 17). We probably recognize it in two

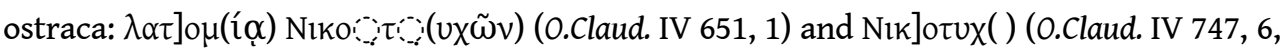

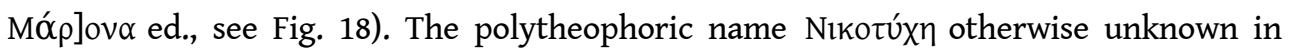

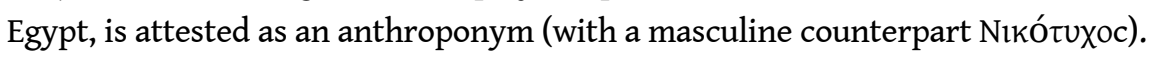


Fig. 16

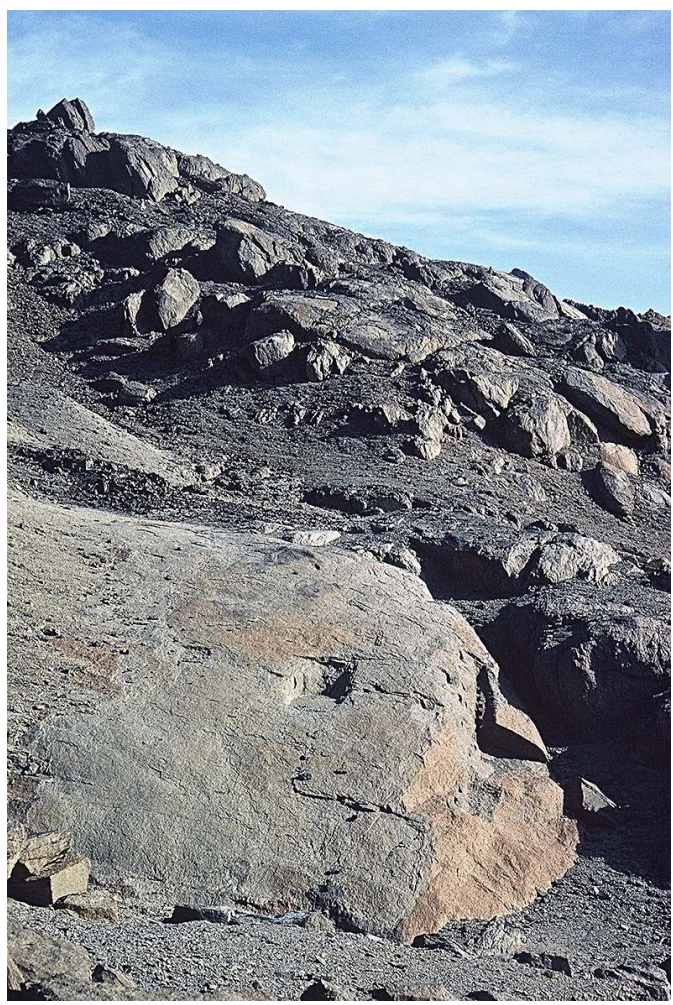

Nikotychai quarry, remained untapped.

(c) ADAM BÜLOW-JACOBSEN

Fig. 17

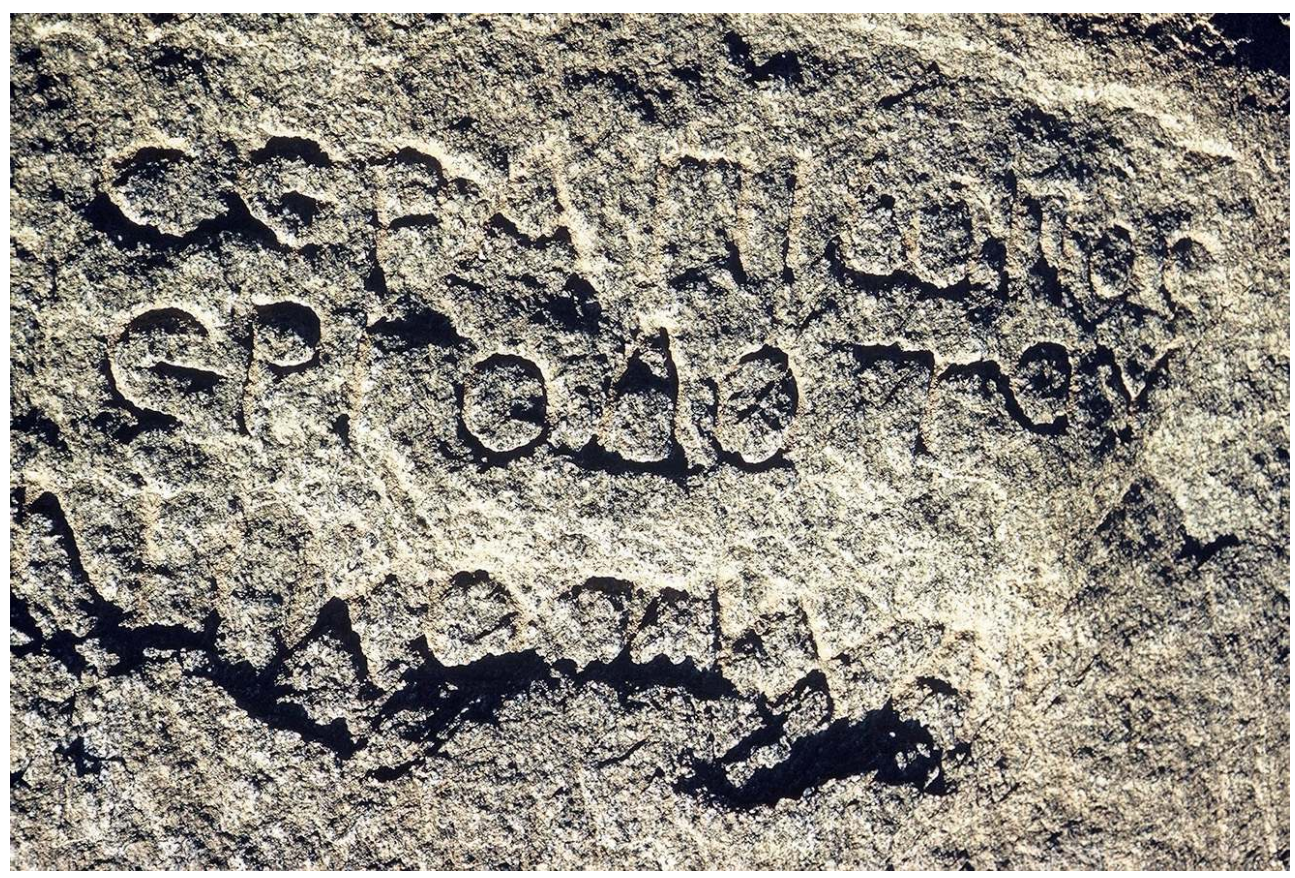

THE SIgNPOST OF NIKOTYCHAI QUARRY, WITH THE NAME OF THE FOREMAN.

(c) Adam Bülow-Jacobsen 
Fig. 18

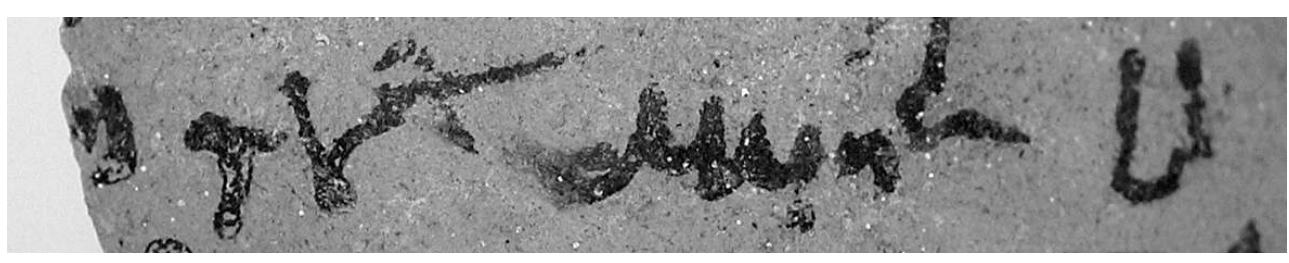

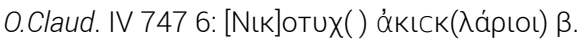

C) ADAM BÜLOW-JACOBSEN

\section{$\Pi \lambda \omega$ T́va (Hadrian?) $^{2}$}

This name appears only in 0.Claud. IV 739, a note assigning 16 men "to Plotina's column,"

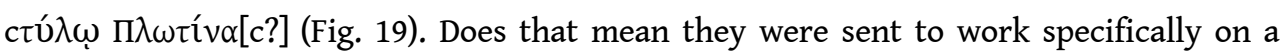
column in a quarry called Plotina or was this quarry, as for $\Lambda$ outń $\rho$, named after the object that was extracted, as would happen with a column which would itself have a

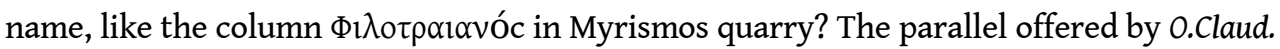

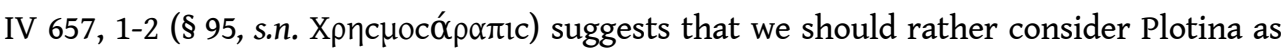
the name of the quarry.

Fig. 19

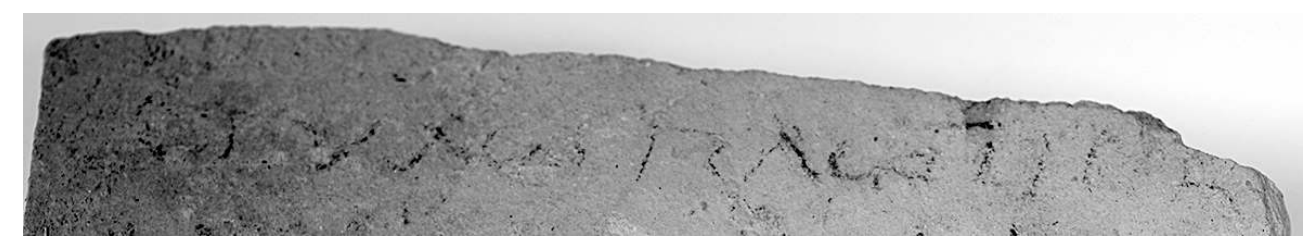

O. Claud. IV 739, 1.

(C) ADAM BÜLOW-JACOBSEN

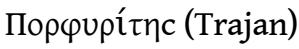

This name appears in two lists among quarry names (0.Claud. IV 705 and 706) and in a delivery order belonging to a series of notes about sending quarry equipment (O.Claud. I 17, cf. 0.Claud. IV, p 135). It must, therefore, probably refer to a $\lambda \alpha \tau o \mu$ í $\alpha$ which is the namesake of the metallon. The restitution of this quarry name in the Antonine ostraca O.Claud. IV 841, 49 and 842, 4 is very hazardous.

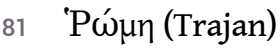

It more likely refers to the goddess Roma than to the city. 'P $\omega \mu \eta$ is never accompanied by

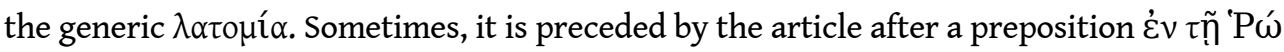

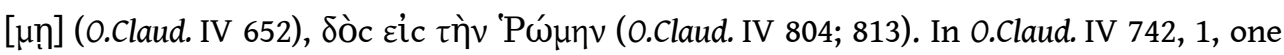

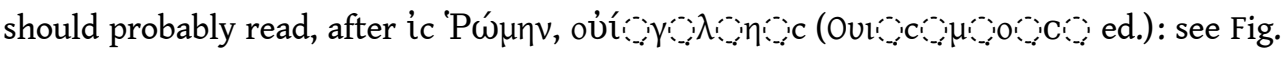
20. 
Fig. 20

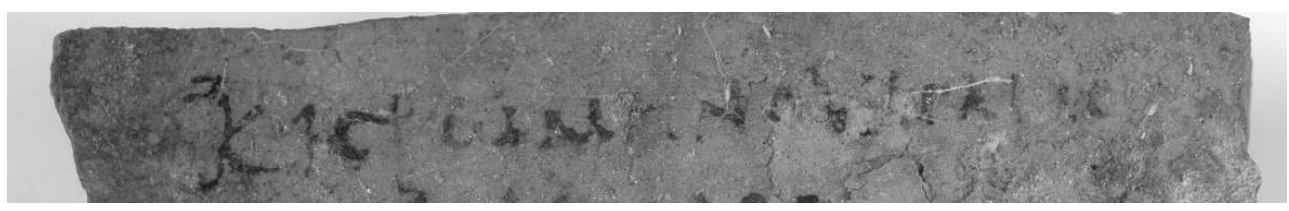

O.Claud. IV 742, 1.

(c) ADAM BÜLOW-JACOBSEN

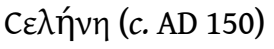

This quarry only appears in two ostraca where its name had been misread:

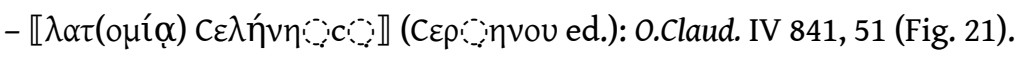

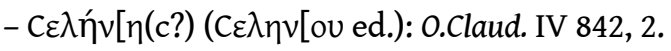

Fig. 21

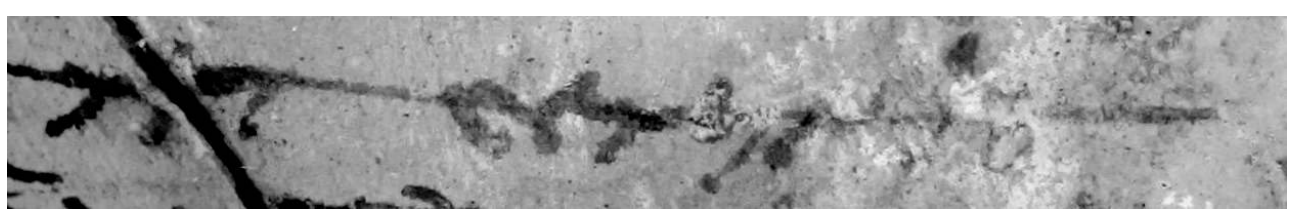

O.Claud. IV 841, 51

(c) ADAM BÜLOW-JACOBSEN

CÉ $\rho \alpha \pi i c{ }^{?}(c . \mathrm{AD} 150)$

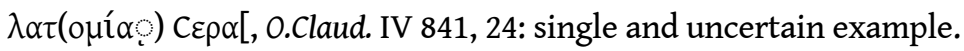

$c \omega \omega \zeta \zeta o u c \alpha$ (Trajan)

Evidenced only in a Latin fragment (ex latomia Sozusa, 0.Claud. IV 846, 3). This epiclesis is not common in Egypt: we only know a cult of Isis Sozousa at Ekregma in northern Sinai ( P.Oxy. XI 1380, 76), and an Arsinoe Sozousa Street in Alexandria.

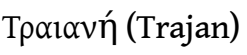

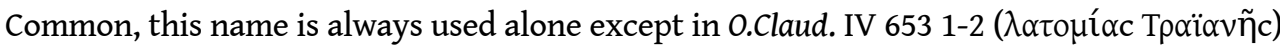

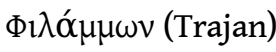

Philammon appears, every time more or less abbreviated and without the generic, in three lists of quarry names in the dative (O.Claud. IV 775, 10; 776, 7; 777, 3).

W. Swinnen has demonstrated that Philammon was an old Greek anthroponym, probably a hypocoristic of $\varphi \imath \lambda \alpha$ á $\mu \varepsilon v o c .{ }^{76}$ Widespread in Cyrenaica because of an homophony with the Libyan names in $-\alpha \mu(\mu) \omega v$ and with the name of the local god Ammon, it is also well attested first in Ptolemaic, then in Roman Egypt, where it benefitted from the second century CE fashion for anthroponyms ending in -ó $\mu \mu \omega v$. Swinnen thinks that the popular etymology associating $\Phi 1 \lambda \alpha \alpha^{\prime} \mu \omega \nu$ with the theonym 'A $\mu \mu \omega v$ is late, since genealogies of the type Philammon son of Ammonios do not occur before the end of the first century $\mathrm{BC}$ (BGU IV 11633 [16-13 BC]; SEG XXVI 1839, col B, 13 [first century BC-beginning of the first century CE]); secondly, Fr. Dunand, as Swinnen reminds us, has established that there are no theophoric names in -ó $\mu \mu \omega v$ in the Ptolemaic era.

How did popular etymology understand the name Philammon? We know that in Greek compounds, the element $\varphi \imath \lambda_{0}-$ has an active sense ("who loves") when in first position, 
but passive ("beloved") in second; however, this rule does not apply strictly to anthroponyms (Schwyzer 1939 I p. 635: Agelaos, "leading the people," has the same meaning as Laagos). This latter consideration allows us to avoid the aporia of a pagan name meaning "who loves Ammon," the concept of loving a god being deemed foreign to pagan thought: so, Philotheos, so widespread in the Christian period where it means "loving God" would be in pagan times (where it is also rare), the equivalent of Theophilos ("beloved by the God"). But how should the name $\Phi \imath \lambda \alpha ́ \mu \mu \omega v$ be understood when bestowed on a quarry in the time of Trajan? The meaning "Beloved of Ammon" would be satisfactory for a quarry, presented as being under the protection of the god, but the absence of the equivalent *'A $\mu \mu \omega v o ́ \varphi \imath \lambda$ c makes this hypothesis weak.

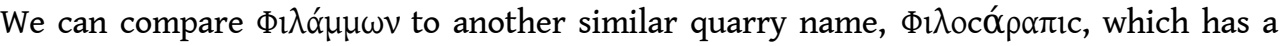
clear etymology. It was originally a title that falls into the category of loyalist epithets

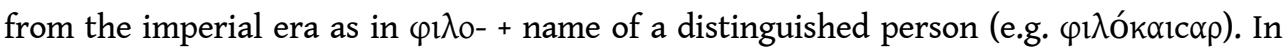
this case, there is no doubt that $\varphi 1 \lambda_{0}-$ has an active sense. But is it the same when the second element is a theonym? M. Malaise, rallying to the position of Swinnen considers that $\Phi ı \lambda_{\text {ocó }} \rho \alpha \pi i c$ means: "Who is beloved by Serapis." ${ }^{77}$ But would the element $\varphi \imath \lambda_{0}-$ have two different meanings when, in AD 193, the archiereus Ulpius Serenianus tacked onto his name the epithets $\varphi \imath \lambda o \kappa o ́ \mu \mu о \delta o c ~ k \alpha i ̀ ~ \varphi \imath \lambda o c \alpha ́ p \alpha \pi ı c ?^{78}$ I do not think so. Similarly, in Ephesus Vibius Salutaris, an official of equestrian rank who had been generous with the temple of Artemis, is honoured with the title philartemis which is added to that of philocaesar. ${ }^{79}$ In an inscription from Didyma, the philodionysoi who question the oracle are an association of "Friends of Dionysus." ${ }^{80}$ Conversely, would these compounds $\varphi i \lambda_{0-}+$ theonym have taken a passive sense when employed as anthroponyms, which seems to have been attested (except for $\Phi ı \lambda$ 入có $\rho \alpha \pi \imath c)$ only in Egypt (where we also encounter the

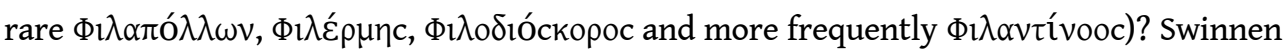

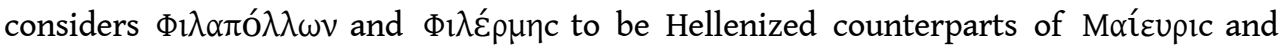

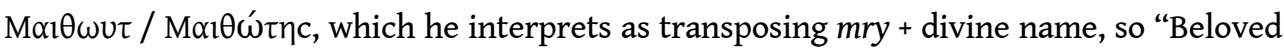
of Horus / Thoth." But this etymology, proposed by Vergote, is not authoritative; it has not been retained in the Demotisches Namenbuch, which assigns another etymology to

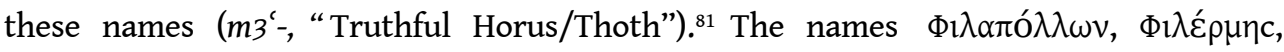

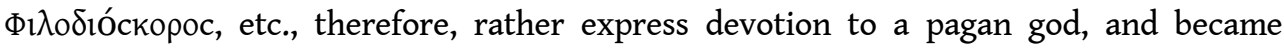
popular because of the fashion of the imperial period for loyalist epithets.

Although semantically it seems more satisfactory to think that the quarry names Philammon and Philosarapis meant "Beloved of Amon, of Serapis," who consequently, watched over the success of the work, I think that these names meant "devotee of" these gods. They are paralleled by the quarry name Philoc(aesar?) and the column Philotraianos (cf. s.n. Mupıcuóc, § 75).

91 Philoc()

The name of this quarry (Peacock Nos. 11-13) is known only by a dipinto written in red ink under the base of the giant column which remains in place at the head of the PillarWadi. It is so faded that we had never been able to read it, until $14^{\text {th }}$ January 2017, when a visit to Mons Claudianus gave us the opportunity to take a digital photo that was then treated with the software DStretch (Fig. 22). The dipinto is formulated on the same model as the inscription at the Harpocrates quarry, which also belongs to the caesura of Epaphroditos. 


\author{
[c(aesura) $]^{?}$ Ep(aphroditi) \\ [e]x lat(omia) \\ [P]hiloc()
}

Fig. 22

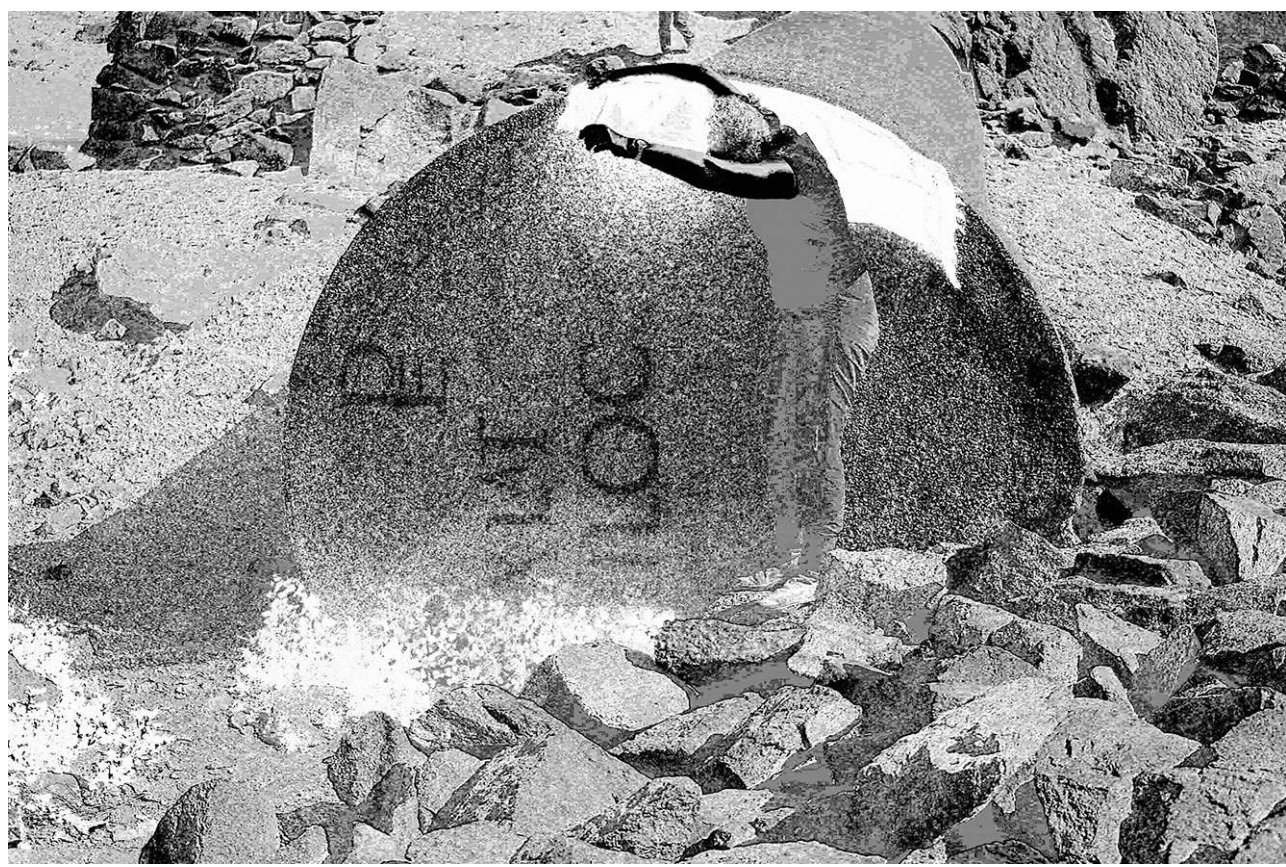

DIPINTO UNDER THE BASE OF THE GIANT COLUMN. THE BAD LIGHT FORCED US TO COBBLE TOgETHER A MAKESHIFT UMBRELLA.

(C) ADAM BÜLOW-JACOBSEN

The reconstruction of c(aesura) is derived from the offset position of Ep(aphroditi). No ostracon gives us a clue for completing the quarry name: was it a loyalist epithet ( Philocaesar rather than Philocommodus, since no major works at Mons Claudianus can be placed under Commodus)? Or just a personal name?

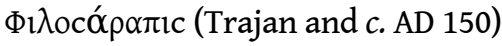

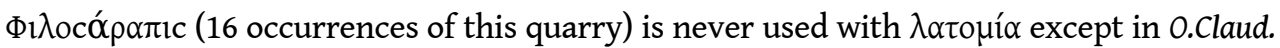
IV 841, 47 (c. AD 150), a block count where the scribe systematically uses the generic, and which reads $\lambda \alpha \tau() \Phi i \lambda o c \alpha$ p $\alpha \pi i c$. Philosarapis, which is originally a kind of honorific title (cf. $\$ 88-89$ ), is attested as a personal name from the end of the second century AD, hence after the Trajanic occurrences of our toponym. If Philosarapis referred to a person,

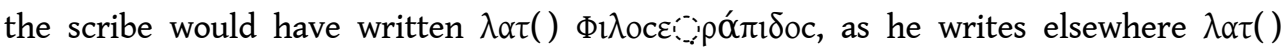
Móp $\rho$ voc. Nevertheless, $\lambda \alpha \tau$ (opía $\alpha$ ) should be restored, in this count, in the dative,

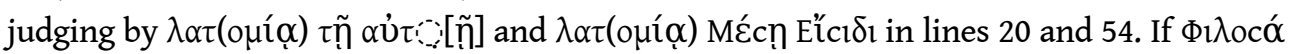

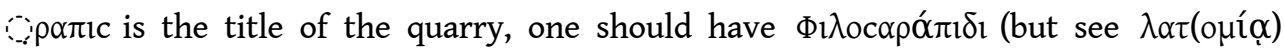
Kó $\chi \lambda \alpha \xi$ lines 63 and 64). I find it, however, difficult to explain the masculine article,

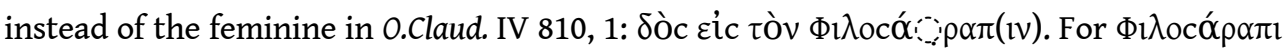
c should be feminine as well as masculine, as $\varphi \imath \lambda$ ó $\alpha \tau$ pıc. In fact, it behaves as if it were a theonym.

There was probably another quarry with the same name when work resumed at the end of the second century CE. In a letter to the procurator metallorum, the quarry workers 
report that, not knowing the official name of the quarry in which they work, they have on their own initiative called it "Philoserapis" (O.Claud. IV 853, 19 [c. AD 186/187]).

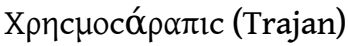

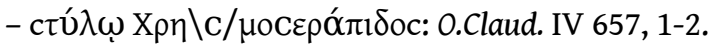

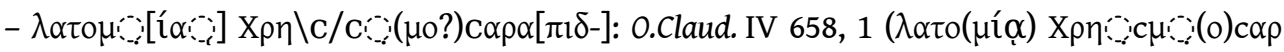
( ) ed.). The infrared photo reveals, under the quarry name, an erased line which I cannot read, and does not help to understand the tangled traces that we would like to read as $\mu \mathrm{o}$ - (fig . 23).

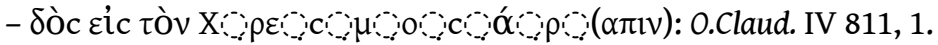

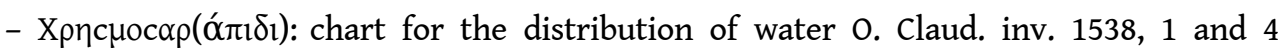
(Cuvigny 2005).

Fig. 23

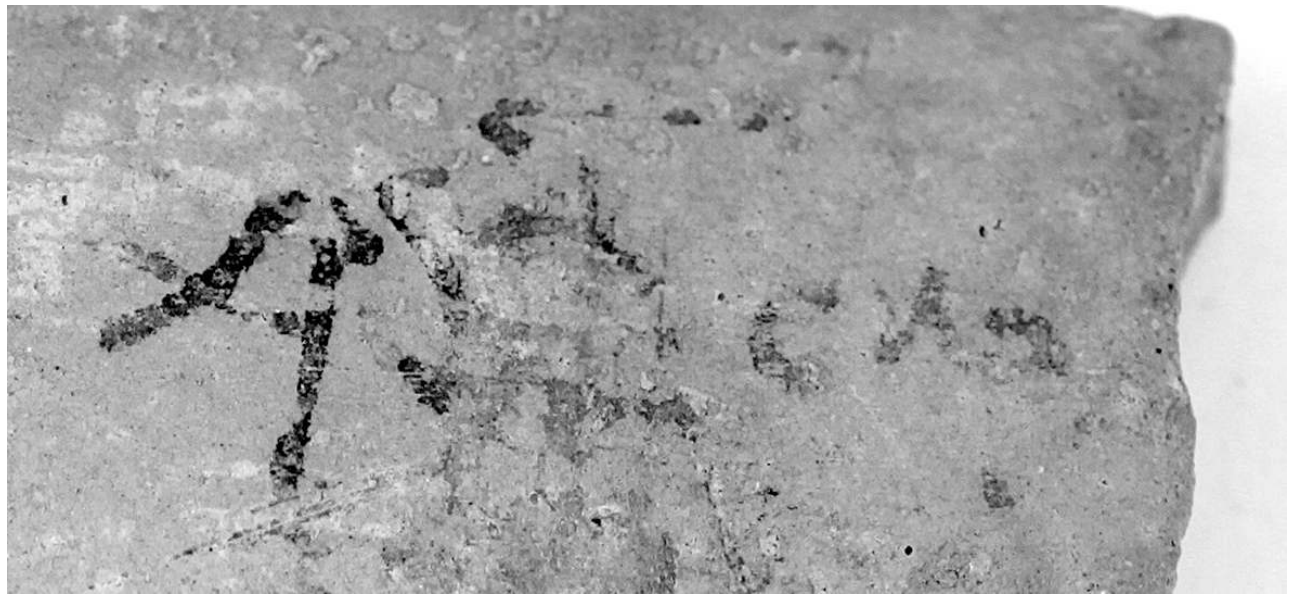

O.CLAUD. IV 658, 1 (DETAIL).

(C) ADAM BÜLOW-JACOBSEN

Loewe 1936 does not cite any compound theophoric toponym, ${ }^{82}$ but we can compare Xpпc

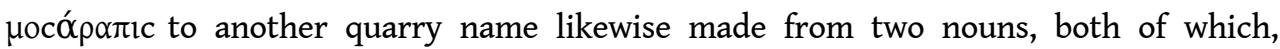

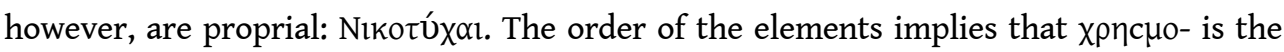
modifier, so that this quarry name should be understood as "Serapis of the oracle/

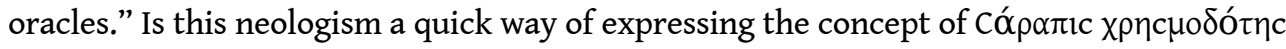
? Is it an "anecdotal" 83 toponym, reminiscent of a prophetic dream sent by Serapis to some foreman?

\section{Conclusion on the toponomy of quarries}

Table 3

\begin{tabular}{|l|l|l|l|}
\hline dynastic & theophoric & anthropophoric & descriptive \\
\hline
\end{tabular}




\begin{tabular}{|c|c|c|c|}
\hline 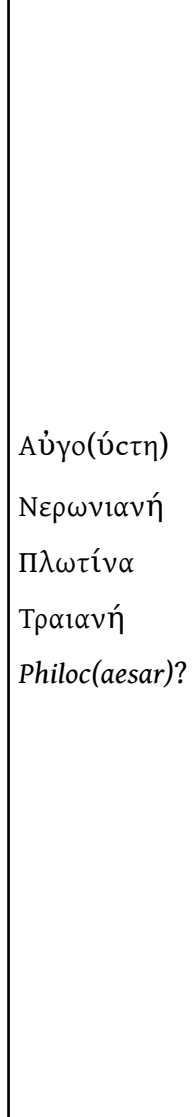 & 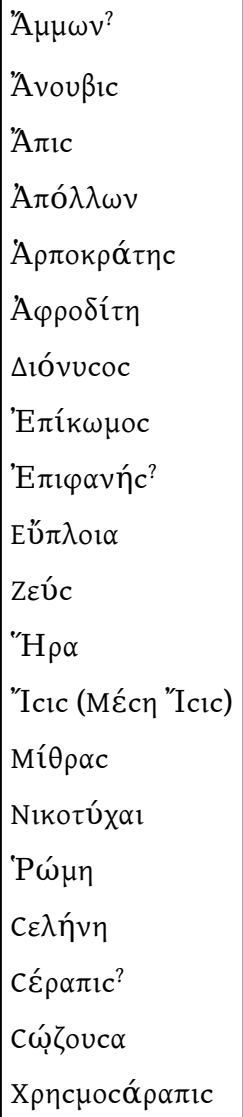 & 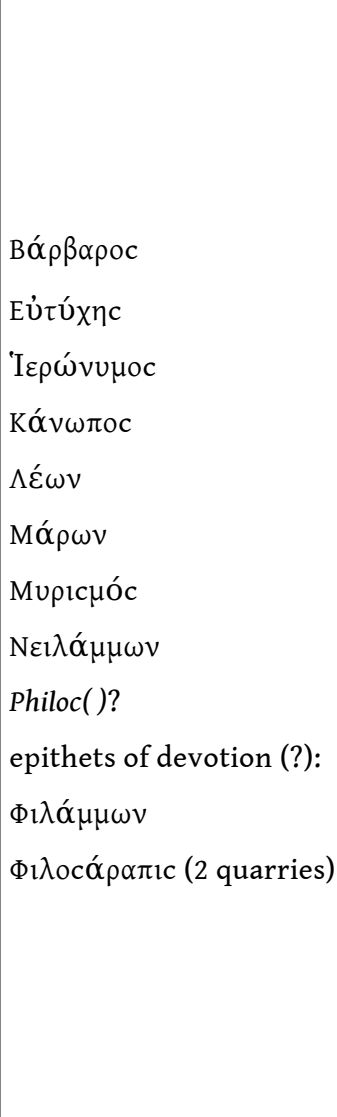 & 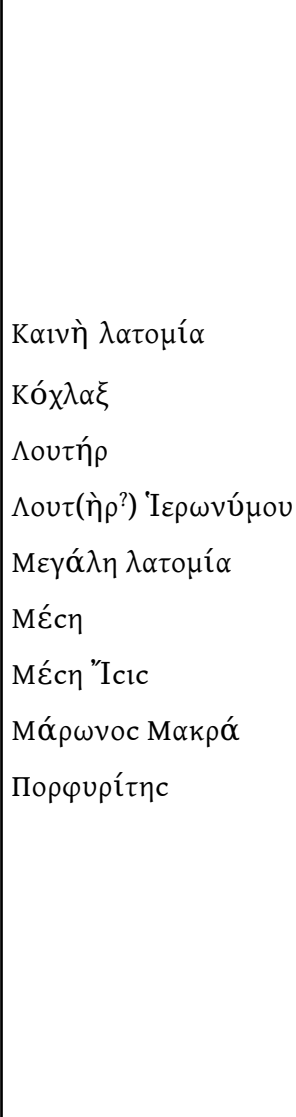 \\
\hline
\end{tabular}

TAXONOMY OF THE QUARRY NAMES IN MONS CLAUDIANUS. usually theophoric and allegorical, as highlighted by P. Heilporn in his comment to P.Bingen 77, p. 343 sq. ( $2^{\text {nd }}$ c. CE). Three merchant ships in this papyrus have the same names as some of our quarries: Zeus, Aphrodite, Selene. See also the ship called Avtívooc

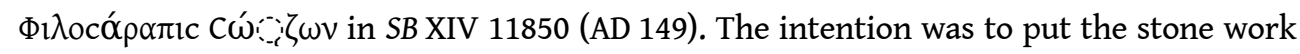
under the protection of a god whose goodwill was sollicited by calling the quarry "devotee of (such-and-such god)." The extraction of monoliths was at the mercy of unexpected weaknesses of the material, undetectable until it was too late, as evidenced by the basins and broken or split columns that were abandoned on site. In the letters in

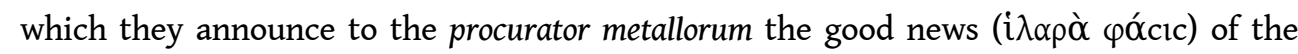
completion of an order, the quarry workers are quick to attribute their success to Serapis, assisted by the Tyche of Claudianus and the baraka (which they also call Tyche) of the procurator. $^{84}$

The generic $\lambda \alpha \tau o \mu$ í $\alpha$ is only expressed when the specific is an appellative adjective;

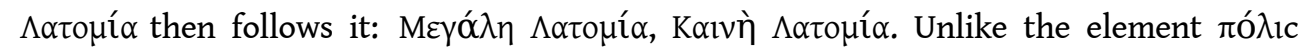

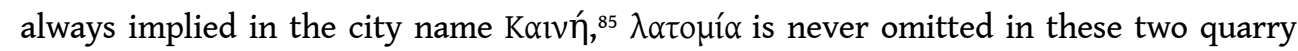

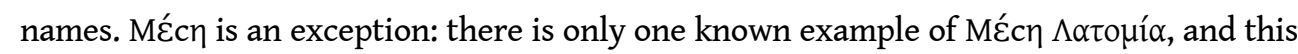
quarry is otherwise mentioned only as MÉcๆ.

While Loewe 1936 notes no specific element of theophoric toponyms that is a compound (it is always a pure theonym or a derivative), we see several compounds among the theophoric quarry names: besides the common Philammon or Philosarapis, also known as 


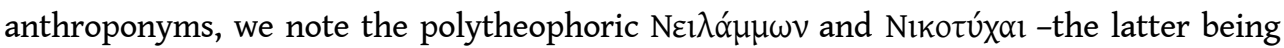

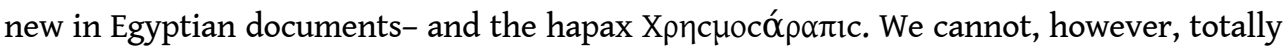
exclude the possibility that Philammon, Philosarapis and Nilammon are anthroponyms referring, as do Leon, Hieronymos or Myrismos, to real people, supervisors with whatever status on the working site.

Whether drawn from a god or a human, quarry names follow the same syntactic pattern.

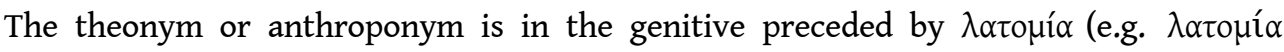
A $\pi$ ó $\lambda \lambda \omega v o c)$, but, when it happens to be used alone, instead of staying in the genitive (as in the case of another microtoponym at Mons Claudianus, the well of Cattius, designated

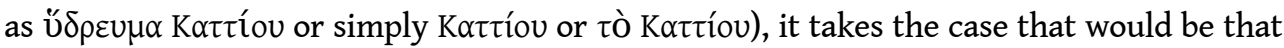

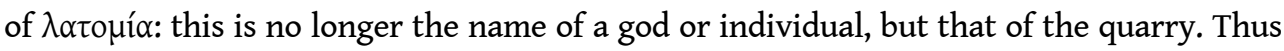

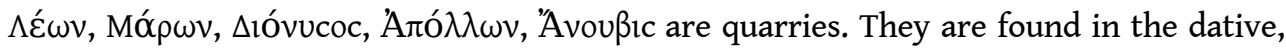

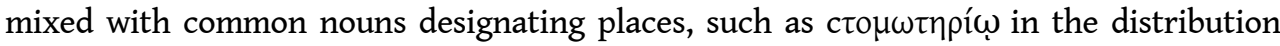
lists of 0.Claud. IV 769-787; in the series of delivery orders 804-819, those names, despite the general trend in Greek towards the omission of the article after a preposition, ${ }^{86}$ are

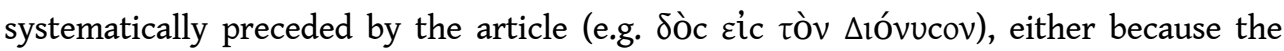

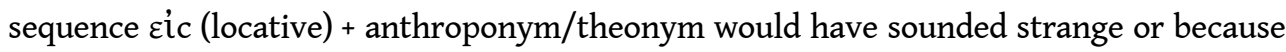
it is customary, according to Mayser, for the Lokalnamen. ${ }^{87}$

It is rare that, used after $\lambda \alpha \tau o \mu$ í $\alpha$, the theonym / anthroponym, instead of being a complement to the name in the genitive, is in apposition: the only clear example is in

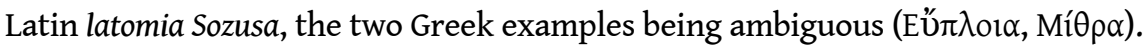

In general, it is unclear who the eponymous persons of the quarries were. In the case of the Latin account in O.Claud. IV 843, where Hieronymi is an entry along the same lines as Cochlax, we can say that the quarry took the name of the architect Hieronymos. But is the

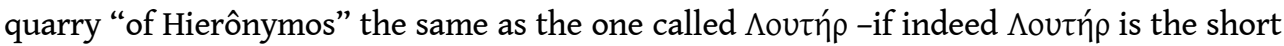

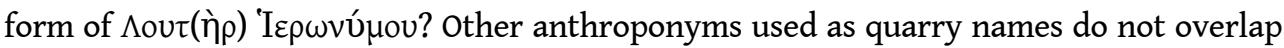
the prosopography of the managerial staff. It is possible that these Maron, Myrismos, Leon, were ergodotai (foremen) whose working sites did not have a name -unlike the Nikotychai Quarry, equipped with a sign announcing both its name and that of its foreman Sarapion.

The late ostracon 0.Claud. IV 841 differs from earlier texts in that the generic $\lambda \alpha \tau o \mu$ í $\alpha$, so often omitted otherwise, is systematically employed in front of the specific element. It is

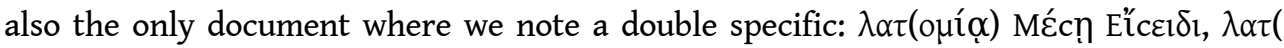

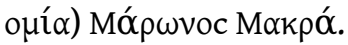

\section{On the fringe of quarries: krepides and kopai}

104 In several lists of $\lambda \alpha \tau o \mu$ í $\alpha$ there are also names of $\kappa \rho \eta \pi i ́ \delta \varepsilon c$, some of which are called after a quarry. Documents such as O.Claud. IV 872 and 880 strongly suggest that these "quays" are platforms for putting blocks on wagons, as can be seen at the bottom of the

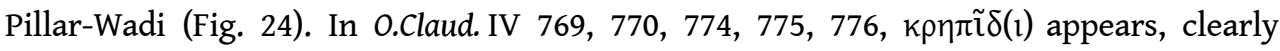
without further specification, in lists of microtoponyms in the dative which are generally

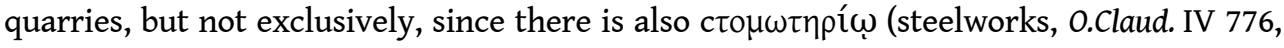
12). It could be what some toponomasticians call "appellative," ${ }^{88}$ giving the word the restricted sense of a generic used to designate a specific place, in other words, a common categorising name used as a toponym: in this case, "the Quay." In the charts of water 
distribution, $\kappa \rho \eta \pi \tilde{\imath} \delta \mathrm{l}$ is, however, accompanied by a determinant. In the best preserved of these charts, inv. $1538,{ }^{89}$ we find, among the latomiai and other microsites which received

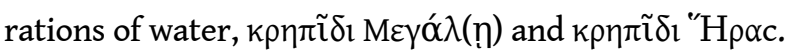

Fig. 24

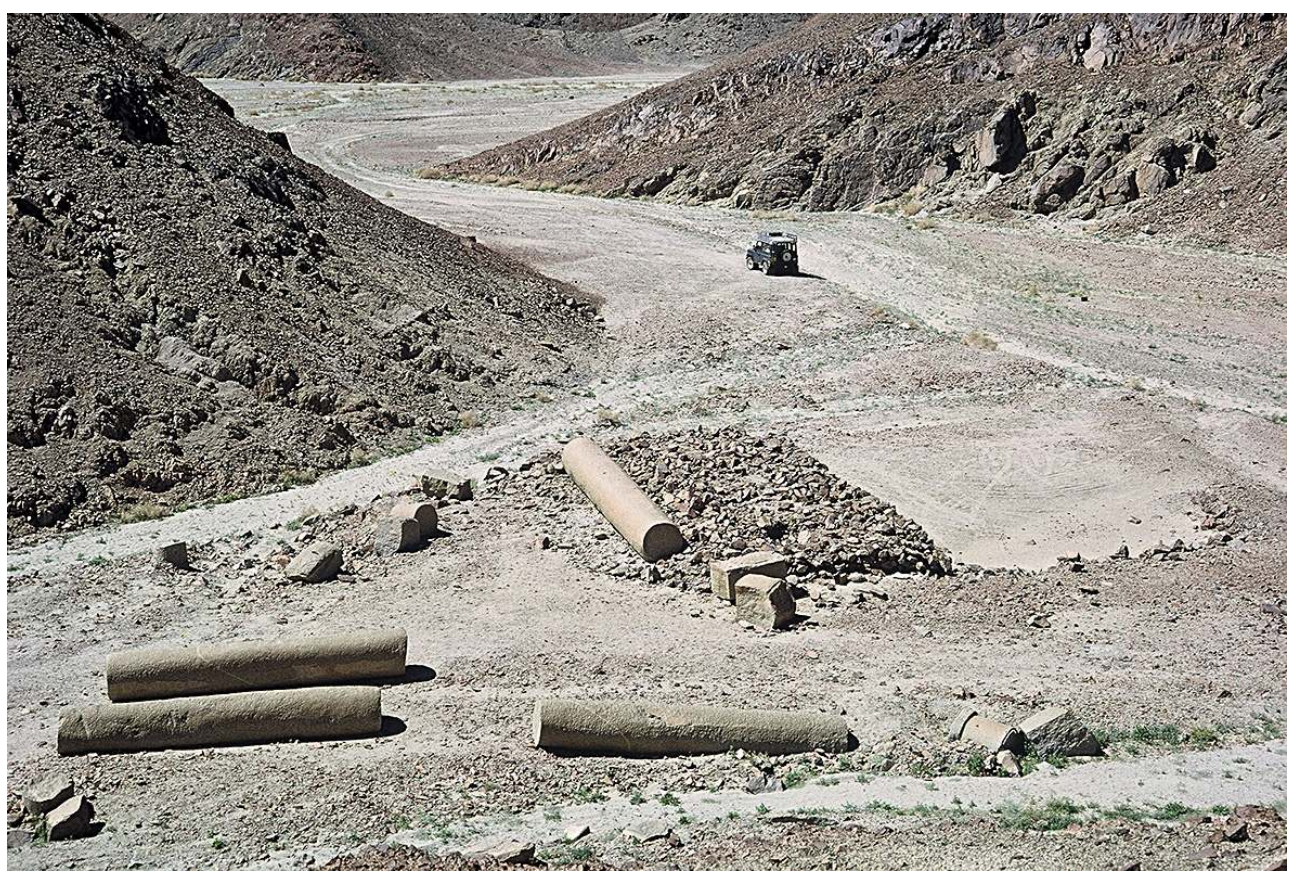

Mons Claudianus. Column shafts on the krepis at the bottom of the Pillar-Wadi.

(C) ADAM BÜLOW-JACOBSEN

The term коти́ appears late in the ostraca of Mons Claudianus: four documents mention it, dated to $c$. AD 150 according to stratigraphy and prosopography. A. Bülow-Jacobsen convincingly suggests that it is a calque of caesura, a term that recurs in quarry-marks at

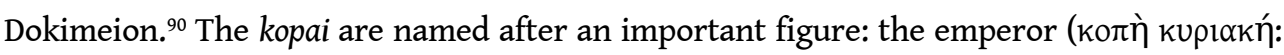

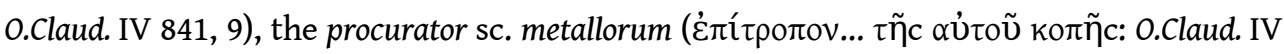

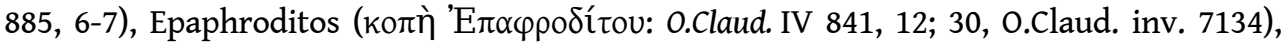

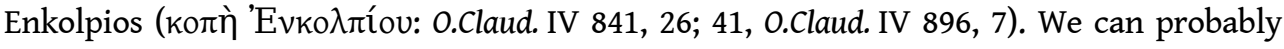

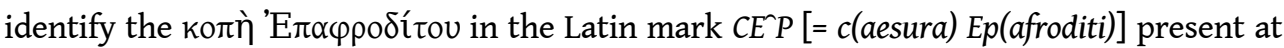
many quarries. The large account 0. Claud. IV 841 shows the latomiai as subdivisions of kopai. It is unclear whether kopai corresponded to geographic areas of the metallon, or whether they were merely administrative categories, the meaning of which escapes us. Although it does not appear in the Trajanic ostraca, the system of the kopai must have existed before AD 150, since Enkolpios is known as procurator metallorum under Trajan ( I.Pan 38); concerning Epaphroditos -whose name is more common- he is probably an imperial slave who was conductor metallorum in the period when work in Claudianus and Porphyrites resumed under Hadrian, after the Jewish Revolt of 115-118 (I. Pan 21 and 42). 


\section{Forts and fortlets (praesidia)}

\section{The toponyms on the amphora of the Barbarians (O.Krok. I 87)}

O.Krok. I 87 is an amphora which the curator of Krokodilo used in year 2 of Hadrian's reign, to copy circulars passing through his hands. Many of them mention a mysterious Parembole, ${ }^{91}$ as well as several praesidia with names that are not otherwise attested on ostraca in the desert. These sites are probably outside Mons Berenicidis.

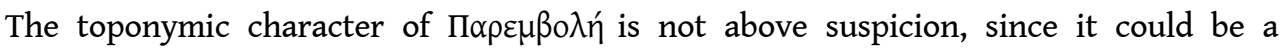
common noun meaning "camp" (= Latin castra). Two circulars recount military incidents

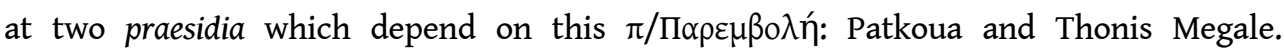

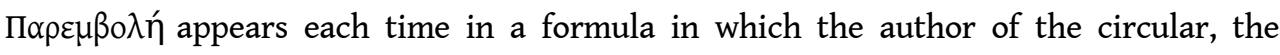
centurion Cassius Victor, says that he attaches the copy of reports sent from these two

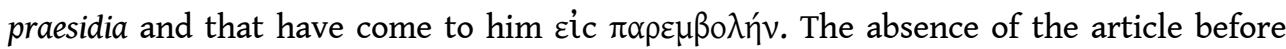
$\pi \alpha \rho \varepsilon \mu \beta о \lambda \eta v v$ is not a reliable indicator for deciding if this word is a toponym or a common noun. However, two good arguments suggest that $\pi \alpha \rho \varepsilon \mu \beta ం \lambda \eta ́ v$ does not simply mean "camp". First, Cassius Victor addresses himself to a number of recipients scattered over a wide area that exceeds the limits of the Berenike Desert (since it is assumed that his correspondence will reach several prefects). Second, the language is the detailed and codified, as shown by the care with which he states his identification and that of his

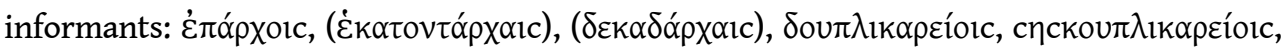

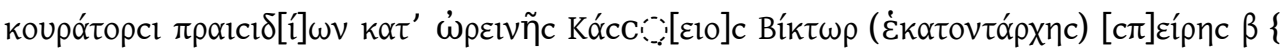

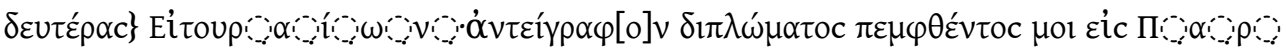

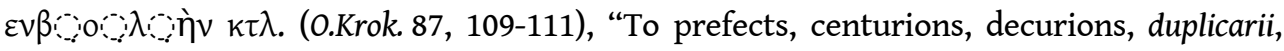
sesquiplicarii, curators of the praesidia of the desert, Cassius Victor, centurion of Cohort II \{Second\} of the Itureans. Copy of a diploma sent to me at Parembole etc."

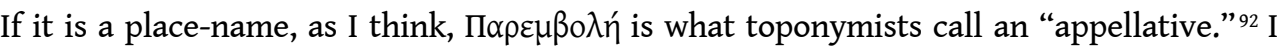

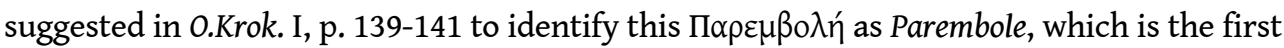
fortified Roman site south of Syene according to the Antonine Itinerary (161.2).

We have seen that the two praesidia which depend on the castra of Parembole were called

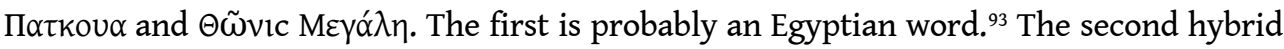
combines an Egyptian noun ( $\Theta \tilde{\omega} v i c=$ "The Lake, The Pond") and a Greek appellative adjective.

0.Krok. 87, 68 shows a third name for a praesidium, Nıtpíal: one of the recopied circulars emanates from a prefect, ${ }^{94}$ Cassius Taurus, and introduces a report from the koupó $\tau \omega \rho$

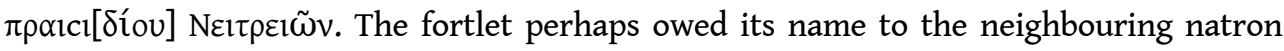
deposits of Laton Polis (O.Krok. I, p. 142).

\section{Praesidia on the route to Myos Hormos}

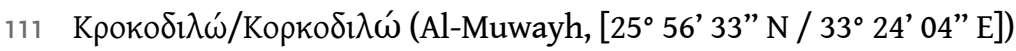

The praesidium of Krokodilo takes its name from the profile of the rocky hill which overlooks it, when viewed from the northeast. The resemblance so struck a traveller that he represented the hill in the form of a crocodile with a rounded snout in a rock graffito in the area (Fig. 25a and 25b). ${ }^{95}$ 
Fig. 25a

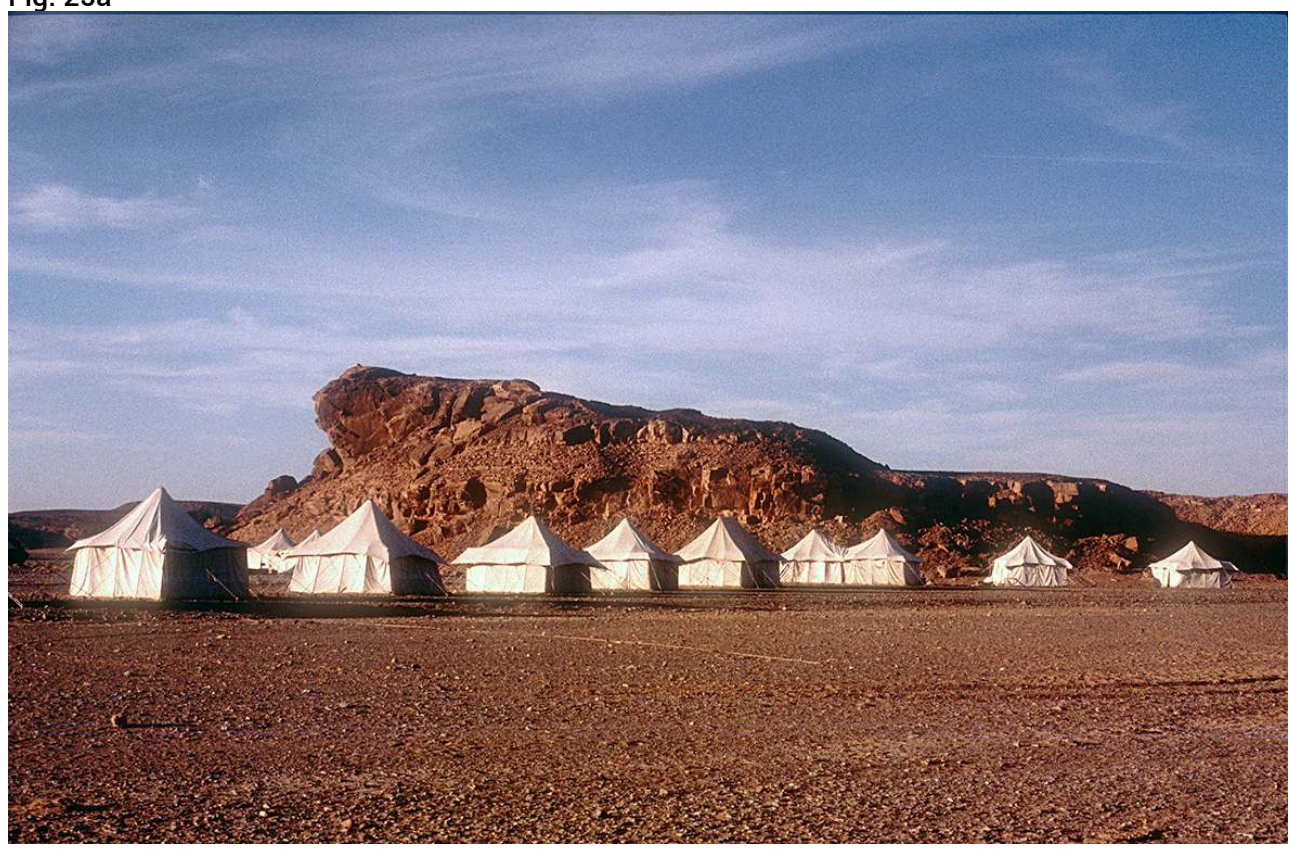

The rock of Krokodilo seen from the northeast.

(c) Hélène Cuvigny

Fig. 25b

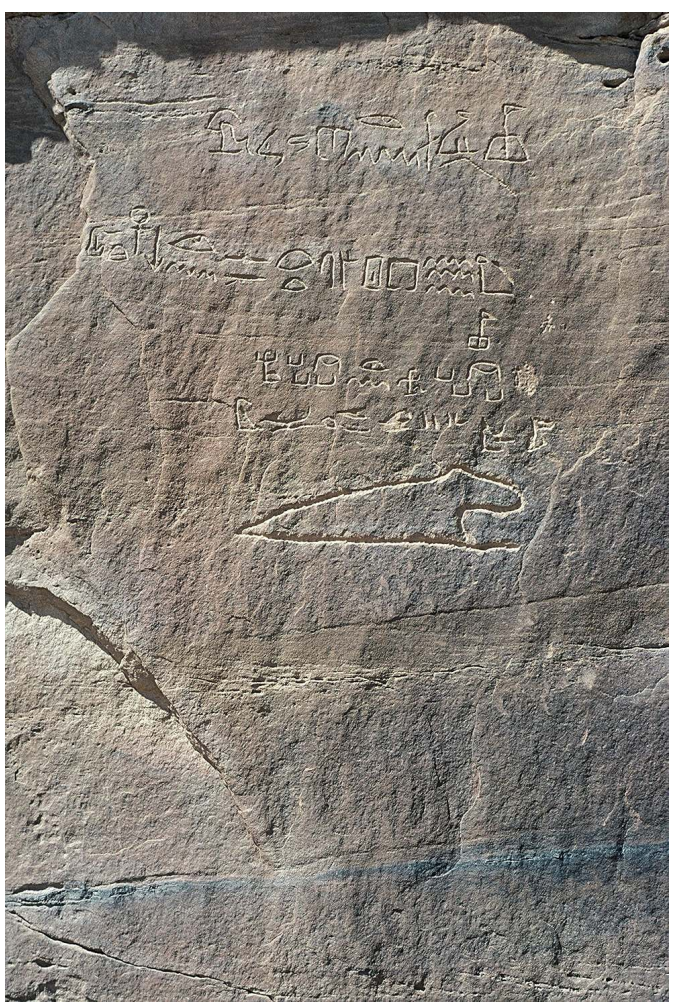

A rock graffito on a nearby cliff, probably inspired by the shape of the hill.

(C) HÉLÈNE CUVIgNY 


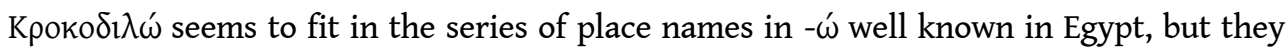
are usually late recharacterizations from the Byzantine and Arabic periods, such as

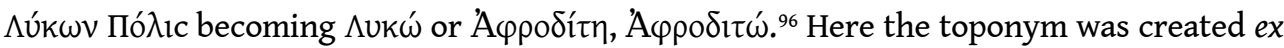
nihilo in this form, and, moreover, in the early empire, since Krokodilo was founded at the end of the first century $\mathrm{CE}$, probably under Vespasian. Contemporaries were themselves

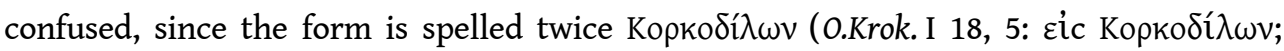
o.Krok. I 78: koupót a popular formation in $-\omega$, , about which the words of $\mathrm{P}$. Chantraine ${ }^{97}$ are illuminating: "the suffix was used mainly to provide derivatives of nouns. Sometimes, it only serves to characterize the word as feminine: $\dot{\alpha} v \theta \rho \omega \pi \omega$ [ [= 'woman' in Laconian dialect], but it is most common in nicknames like $\mu \rho \rho \varphi \omega ́$ ['beautiful,' the name of Aphrodite in Sparta] or

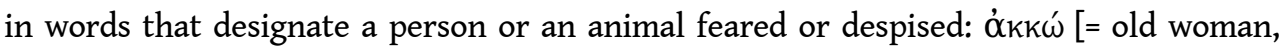
scarecrow], $\mu \mu \omega ́$ [= female monkey, hag]." This expressive suffix reveals that the toponym belongeg to popular speech. Such a whimsical appellation is atypical for a name given by the Romans.

In the epigraphic proskynemata from the Paneion in the Wadi al-Hammamat, this toponym appears firstly in demotic (prs) at the beginning of the Ptolemaic period, then in Greek under the early Julio-Claudian emperors. At that time, Persou is the name of the Wadi alHammamat quarries (called "Rohanou Valley" in Pharaonic times), as proven beyond doubt by the proskynemata "in front of the gods of Persou" engraved on the entrance of the small sanctuary of the village situated opposite the Paneion (25 $59^{\prime} 25^{\prime \prime} \mathrm{N} / 33^{\circ} 34^{\prime}$ 12 " E).

114 Three dated proskynemata mention Persou: Kayser 1993, No. 4= SB XXII 15642 from year 18 of Tiberius' reign (AD 32); Kayser 1993, No. 15= SB XXII 15655, probably from year 10 of the same emperor (lacunose titulature); Kayser 1993, No. 7= SB XXII 15645, dated year 9 without the emperor's name, that Fr. Kayser suggests is not of Tiberius, but Nero (AD 62), due to the position of the graffito on the doorpost.

In the Paneion facing the village, quarry workers carved several Demotic proskynemata, and one in Greek, in which they claimed to be "from Persou and Tamostymis" (c

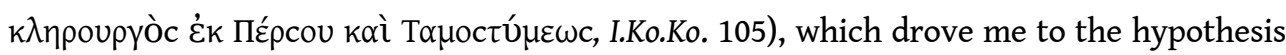
of a complex toponym consisting of a correlated noun phrase (although this structure is mainly attested in Egypt for the names of klèroi). Пźpcou would have been the area of

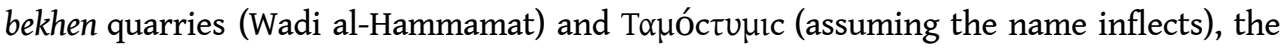
mines of Wadi al-Fawakhir. ${ }^{99}$ Touóctupıc is not attested elsewhere, other than as epiklesis of Isis (Isis T $\alpha \mu \varepsilon c \tau o \mu \varepsilon)$ in a lost stele from Qusayr mentioned by Adolphe Reinach and dating back to year 25 of Augustus' reign (6-5 BC). ${ }^{100}$

The ostraca from Krokodilo and Maximianon contain many references to a praesidium of Persou, where Athena was honoured, and which had a vegetable garden that provisioned these two sites. This praesidium, close to an abundant well, cannot be the village of Wadi al-Hammamat, which does not have a well and which is not a praesidium: it must be near Bi'r Umm Fawakhir, located some $5 \mathrm{~km}$ from the Paneion, but it has been completely destroyed. I deduced that the toponym Persou migrated, and I distinguished between Persou I (the village opposite the Paneion cave of Wadi al-Hammamat) and Persou II (the praesidium next to Bi'r Umm Fawakhir, attested at least from the time of Trajan). An ostracon found in Wadi al-Fawakhir and dating from the reign of Caligula or Claudius ${ }^{101}$ 
reveals the presence of a Roman military post earlier than the ostraca from Maximianon and Krokodilo, but we cannot tell if the name was already Persou or still Tamostymis (if that name was indeed attached to the Wadi al-Fawakhir).

The oldest papyrological reference to Persou predates the ostraca from Maximianon and Krokodilo. This is a receipt on an ostracon belonging to Nikanor's archive found at Koptos, O.Petrie Mus. 112. It was issued in year 2 of Nero's reign (AD 55/56) by a koupó $\tau \omega \rho$ Пદ́pcov. It is difficult to decide where the soldier was stationed: still in the village next to the Paneion of Wadi al-Hammamat where the last proskynemata engraved on the door posts of the chapel door date back to Nero, ${ }^{102}$ or already in the Wadi al-Fawakhir? The migration of the name חع́pcou from the Wadi al-Hammamat (Persou I) to Wadi alFawakhir (Persou II) may have occurred when the village of Wadi al-Hammamat was abandoned: it is a common fact that a toponym migrates from a disused site to a nearby one, and it is not possible for two adjacent sites to have the same name at the same time. ${ }^{103}$ Unless, as J.-P. Brun thinks, the name Tamostymis had fallen into disuse and the

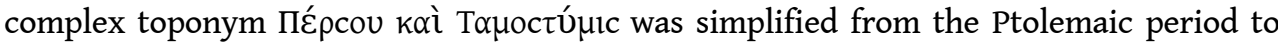

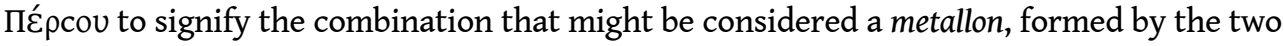
sites.

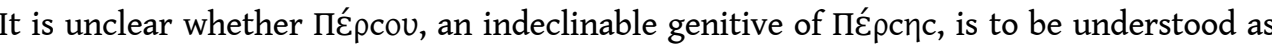
the ethnic or as the derived anthroponym.

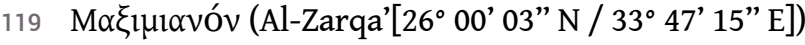

A proprial adjective derived from the anthroponym Maximus. This name probably commemorates an important figure. One naturally thinks of the prefect of Egypt Julius Ursus, who ordered the construction of forts on the Berenike road during Vespasian's reign. Two candidates come under consideration: $C$. Magius Maximus, prefect in year 1 of Tiberius' reign (AD 14/15), and L. Laberius Maximus, prefect in AD 83 (year 2 of Domitian's reign). In the first case, Maximianon would have already been the name of the Julio-Claudian military post, traces of which were found under the dump. In the second case, it would mean that the present praesidium had been built a few years after the Berenike road was developed, in $\mathrm{AD} 79$. The first hypothesis is the more attractive, since it is natural that a military post, when rebuilt, retains its name (cf. for instance the praesidium of Apollonos Hydreuma, which kept the name of the station which predates the praesidium).

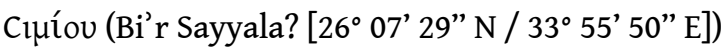

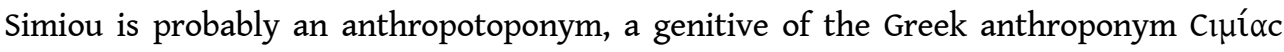

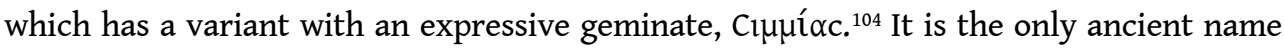
for a praesidium that we know for the section of road between Maximianon and Myos Hormos. Thus, there are three candidates for identification: Al-Hamra', Bi'r Sayyala and Dawwi. O.Max. inv. 920, dating from c. AD 90-125 (according to stratigraphy) clearly shows that the praesidia of Persou, Maximianon, and Simiou directly followed from west to east when the ostracon was written. Dawwi, which is farthest from Maximianon and whose construction date falls within the final phases of Maximianon, can be ruled out. ${ }^{105}$ Al-Hamra' $\left(26^{\circ} 02^{\prime} 18^{\prime \prime} \mathrm{N} / 33^{\circ} 53^{\prime} 29^{\prime \prime} \mathrm{E}\right)$ is today the immediate neighbour of Maximianon in the direction of Myos Hormos, but this fortlet appears to have been built in the second quarter of the second century, which leaves open the most interesting hypothesis that Simiou could be Bi'r Sayyala, a fortlet in which J.-P. Brun's excavations revealed a complex evolution that could date back to the Ptolemaic period (although surveys, 
unfortunately limited, have not revealed Ptolemaic material). Hence the idea that the praesidium would have followed on after the digging of a well, ordered by Simmias, when he was commissioned by Ptolemy III to capture elephants. ${ }^{106}$ The Roman toponym would have retained the spelling without the geminate.

\section{Praesidia on the road to Berenike}

Names of stopovers on the Berenike road have long been known -with some mistakes that ostraca have enabled us to correct- thanks to three written Roman itineraries. The route description by Pliny the Elder, which dates from a period before the construction of the first praesidia in AD 76/77, shows that some of these were positioned around older

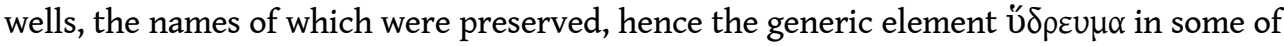
the complex toponyms. We cite them in the order in which they are encountered from Koptos to Berenike.

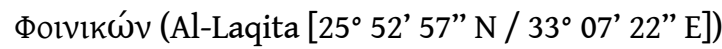

Today there are no remains of the praesidium where the roads to Myos Hormos and Berenike meet, but the palm grove from where it got its name still exists. Фolvikẃv is never preceded by the article.

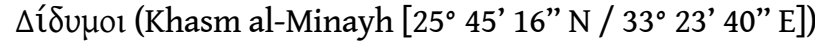

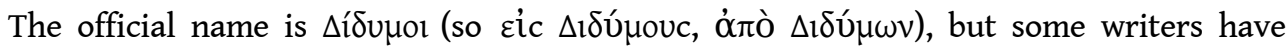
hesitations. Thus, we find the singular in two ostraca of the third century: O.Did. 35, letter of the curator of Aphrodite to Psenosiris, kovi[Ló ]

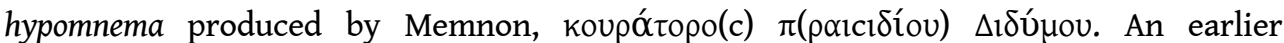
ostracon, ${ }^{107}$ expertly written, is an order from a certain Psenthotes to provide rations to two passing donkey drivers or camel drivers, addressed "to the contractor of the well at

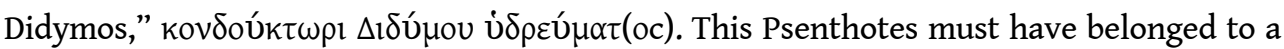
transport company and may not have known the official name of Didymoi, which would

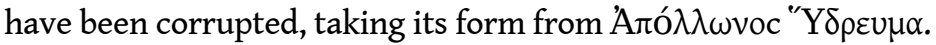

Placed under the protection of the Dioscuri (invoked in the proskynemata of letters written there), ${ }^{108}$ Didymoi belongs to a series of three theotoponyms on the road from Berenike, although $\delta i ́ \delta v \mu o$ is not a proprial name, which explains that, unlike $\Delta$ lóc and A $\varphi$ podírn(c), it is never fixed in the genitive.

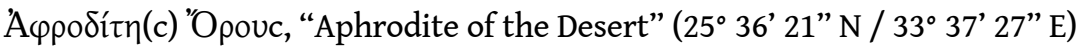

Two ostraca from Didymoi attest the full name of the praesidium. The letter 0.Did.406, a contract of sorts whereby a husband entrusts to another man the protection of his wife, hired as a prostitute at Didymoi, stipulates that the protector give her back to her

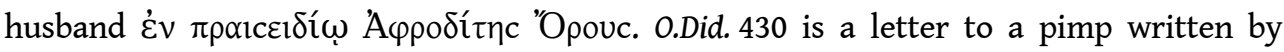

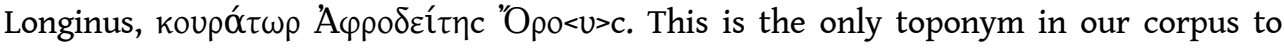
include a locative modifier, ${ }^{109}$ perhaps to distinguish it from another Aphrodite of which we have no knowledge. In Egypt, 'Opouc is only found in the same position in the

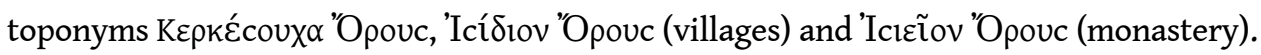

There is some fluctuation in the ending of the theonym, which sometimes remains fixed

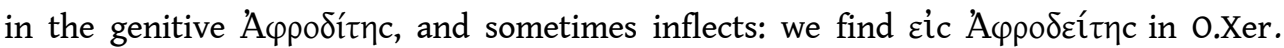

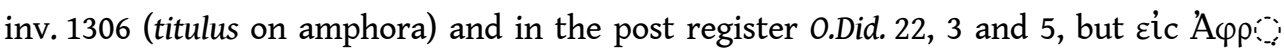

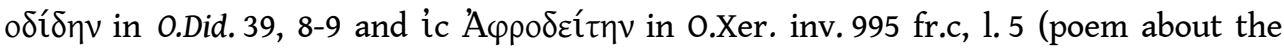

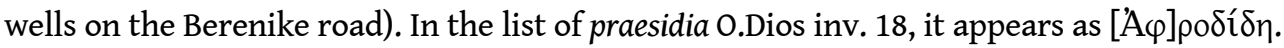


The reading Compasi of It. Ant., already confirmed by the inscription commemorating the construction of the lacci (cisterns) at Apollonos Hydreuma, Compasi, Berenike and Myos

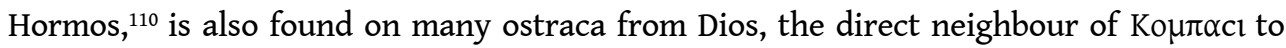
the south. The linguistic affiliation of the name is unclear; one would expect an Egyptian name, like that of its tutelary deity, the goddess Techosis (TÉ $\chi \omega c ı c)$, whose name, attested as an anthroponym, but never as theonym, means "Nubian" (T3-igš). ${ }^{111}$ This is the only deity with a vernacular name, honoured in a praesidium in the Eastern Desert which is due to the age of the site. Here auriferous quartz veins were exploited from the New Kingdom and still under the Ptolemies (from this period there are remains of ore mills, identified as such through the best preserved mills excavated in 2014 at North Samut). ${ }^{112}$ When they opened the Koptos to Berenike road to traffic, the Romans took advantage of the well at Daghbagh, which was presumably already named Kompasi, although Pliny only calls it a hydreuma in his list of stages on the road. The well must have been particularly productive because the ostraca from Dios reveal that Kompasi was both a centre for market gardening and for laundry: the inhabitants of Dios used to order fresh vegetables from Kompasi and to send their dirty laundry there.

$\Delta$ óc (Abu Qurayya [2512’ $\left.52^{\prime \prime} \mathrm{N} / 34^{\circ} 02^{\prime} 03^{\prime \prime} \mathrm{E}\right]$ )

Built, as indicated by its dedication, in $\mathrm{AD} 115 / 116$, this praesidium probably kept the name of the nearby fortlet it replaced, Bi'r Bayza. The latter may have been abandoned because its well was not satisfactory. The excavations carried out by J.-P. Brun and M. Reddé at Bi'r Bayza showed that this fort dates from an earlier period and is probably contemporary with Didymoi and Aphrodites. Hence the idea that it was already called Dios, which fits nicely in the series.

In Latin texts, $\Delta$ oóc is not transliterated but translated, as shown in the Antonine Itinerary ( Iovis), and in a Latin post register, where the curator presents himself as curator praesidio Ioves (l. Iovis). ${ }^{113} \Delta$ óc is a fine example of the spontaneous adaptation in daily speech of an

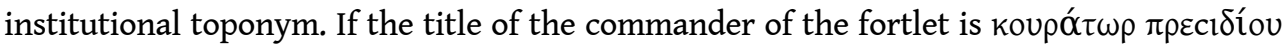
$\Delta$ ióc (O.Xer. inv. 310), the brevity of the word obviously displeased the Greeks who, to say

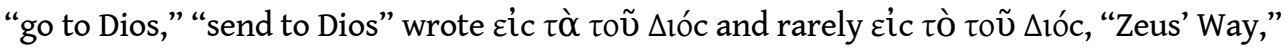

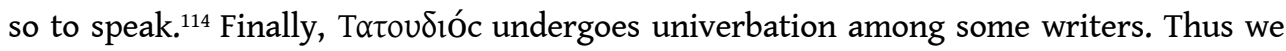

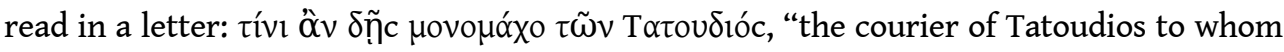

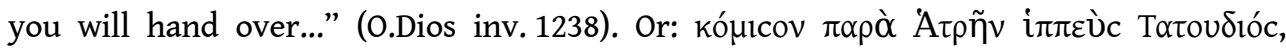
"receive from Hatres, cavalryman from Tatoudios" (O.Dios inv. 507).

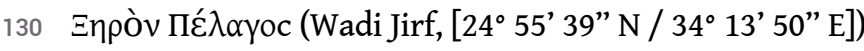

Although the dedication of the fortlet was destroyed, depriving us of a precise date, Xeron Pelagos was probably built at the same time as Didymoi, Aphrodite and Dios / Bi'r Bayza on the orders of the prefect Iulius Ursus, in year 9 of Vespasian's reign. Yet it does not register in the theotoponymic system of these foundations, but received the beautiful descriptive name "Dry Sea," also used for an establishment of unknown character in the vicinity of Mons Claudianus. ${ }^{115}$ The bestowal of two identical names is possible only because the two areas, that of the great imperial quarries, and the Mons Berenicidis, fell under two different administrations, so that there was no risk of confusion. The

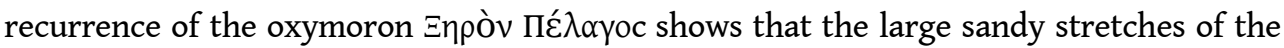
Eastern Desert spontaneously reminded the ancients of dried seas. Literary reminiscences may have influenced the choice of the toponymic authority: at the time when the two 
sites were bestowed this name, that is in the second half of the first century $\mathrm{CE}$, the paradoxical concept of a dry sea appears in several passages in Latin poetry; ${ }^{116}$ it was only later, especially in the Byzantine period, that it is found in Greek, also in poetic texts.

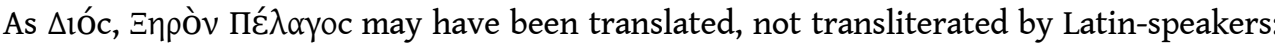
the fortlet is called Aristonis, probably a corruption of Aridum, ${ }^{117}$ in the Antonine Itinerary, which also gives the neighbouring site the Latin form Iovis, while the Peutinger Table and the Ravenna Cosmography have the Greek forms Xeron and Dios respectively.

The place name, which appears only on ostraca from Dios and Xeron, is often abbreviated

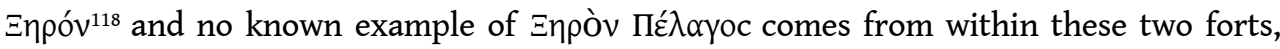
where deposits of ostraca are later, as if the second element had been abandoned in the third century. In fact, there is no trace in the three ancient itineraries of the transferred

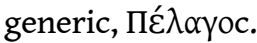

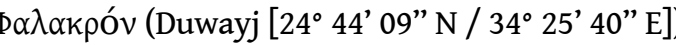

This is probably the name of the remarkably well preserved fort of Wadi Duwayj investigated by Michel Reddé in 2010, during our first season in Xeron, but the toponym does not appear in the few ostraca collected on site, ${ }^{119}$ nor in the letters from Duwayj found at Xeron.

In all ostraca where it appears, the toponym (Falacro in It. Ant., Philacon in Tab. Peut.) is a neuter word of the second declension. The earliest occurrence is in O.Krok. I 61, 4 (102/103 or 121/122), where a Beduin attack is perhaps mentioned, which would have occurred

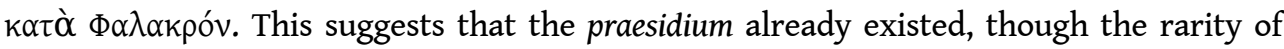
the name in ostraca from Dios and Xeron could have made us doubt this. In the latter site, an immediate neighbour of Duwayj, the name of Phalakron appears only in a poem on the wells (O.Xer. inv. 995, beginning of the third century). In O.Dios inv. 818, a list of praesidia, Xeron directly follows Apollonos (it is true that this list also omits Dios between Xeron and Kompasi).

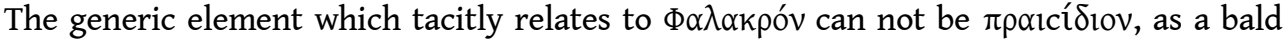
fortlet does not make sense; I am inclined to believe that $\Phi \alpha \lambda \alpha \kappa$ póv is the abbreviation of

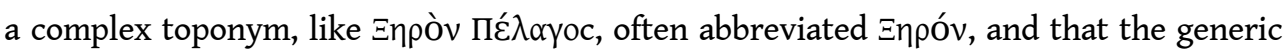

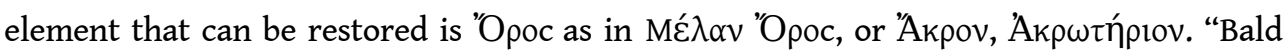
Mountain" would refer to the pointed mountain that stands out behind the praesidium (Fig. 26). 


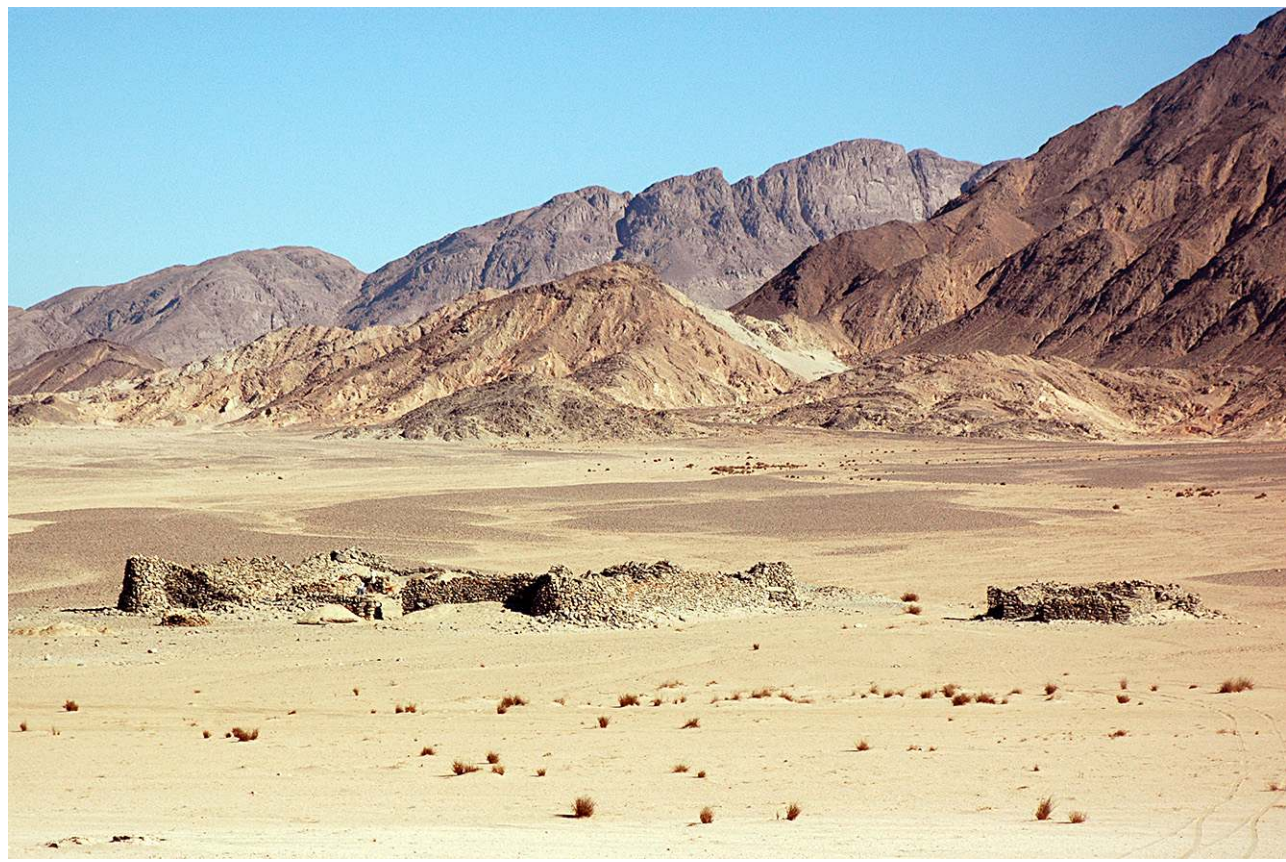

The praesidium of Phalakron. In the background, the bald mountain.

(c) M. REDDÉ

Aлó $\lambda \lambda \omega v o c$ "Y $\delta \rho \varepsilon u \mu \alpha$ (Wadi Jamal [24 32' 06" N / 34 44' 15" E])

The oldest attestation of the site is in Pliny, Nat. 6.102 (mox ad hydreuma Apollinis), but it may be mentioned in an ostracon from the third century BC found at Bi'r Samut (O.Sam.

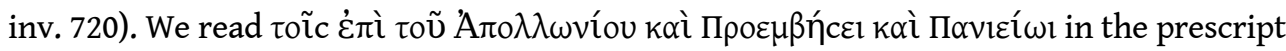
of this circular addressed to supervisors responsible for several successive stages of the road from Edfu to Berenike. Without being completely sure, we have reason to believe that Proembesis is the ancient name of Bi'r Samut; as for Paneion, the last named stage, this can probably be identified with the station located in front of the Paneion of alKanayis. The order of the sites mentioned is, thus, from the south towards the valley. It is,

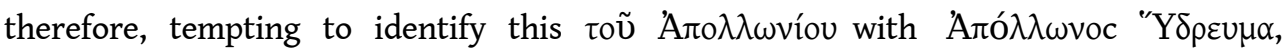
admitting the preterition of the generic element, but also an error with the specific, the theonym having been replaced by an anthroponym.

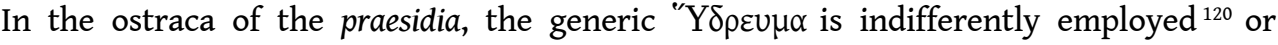
omitted. $^{121}$

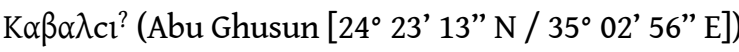

Until recently, the name of the stage situated between Apollonos and Kainon Hydreuma occurred only in the three itineraries of the manuscript tradition, which offer various spellings: Gabaum, Cabalsi, Cabau. It now appears in a poem of the third century on wells found at Xeron (O.Xer. inv. 995, Br. C, 14 [Fig. 27]). Unfortunately, it is compressed at the end of a line and may be abbreviated. Only the first three letters are certain: Kav. . . . The grapheme $b$ of the Latin transliterations can be explained by the spirantization the consonant $v$ in Latin. 


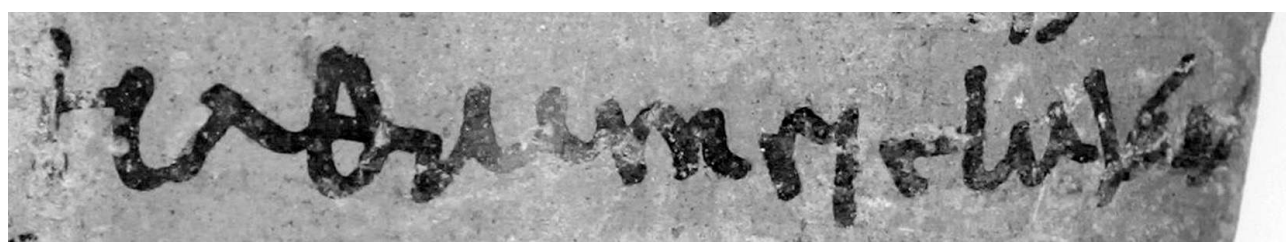

O.Xer. inv. 995, fr. c: Kabalsi? mentioned at the end of line 14.

(c) ADAM BÜLOW-JACOBSEN

At the time of Pliny, there were no wells between Apollonos Hydreuma and Novum Hydreuma. Despite its oddity, the toponym Kabalsi? should be part of the building campaign ordered by Iulius Ursus in AD 76/77. The traditional identification with the visible remains of Abu Ghusun, where the surface ceramics were dated $1^{\text {st }}$ to $2^{\text {nd }}$ and $4^{\text {th }}$ to $6^{\text {th }}$ centuries, ${ }^{122}$ is questionable.

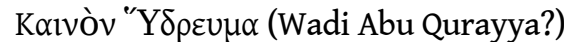

This praesidium on the Berenike road, built on the site of a well already mentioned under the name "New Well" by Pliny, ${ }^{123}$ appears also in the three itineraries of the manuscript tradition. We do not know if this toponym, of which Pliny was aware, dates back to (at least) the Ptolemaic period, or if it refers to the sinking of a new well in the first years of the Principate. Kainon Hydreuma is too far south to appear with any frequency on the ostraca from the fortlets we have excavated. It is however mentioned in the poem found in Xeron, which celebrates the water from the various wells on the Berenike road, listed

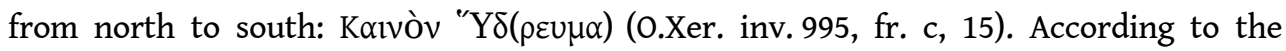
stratigraphy, the poem dates from the beginning of the $3^{\text {rd }}$ century and agrees with other sources that make Kainon Hydreuma the last stage on the road before Berenike.

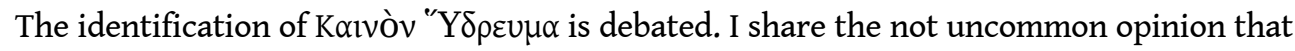
it is the site called today Wadi Abu Qurayya, a cluster of several buildings situated uphill and downhill. Among them, two fortlets are well visible on Google Earth at the bottom of the mountain $\left(24^{\circ} 03^{\prime} 45^{\prime \prime} \mathrm{N} / 35^{\circ} 18^{\prime} 05^{\prime \prime} \mathrm{E}\right)$. Up to now, the most suggestive description is that of Meredith, based on Wilkinson's unpublished travel diary: "Wilkinson found here separate walled enclosures of various shapes and sizes, one being a normal Roman square but without bastions and another a square but with one rounded end (with bastions), closely resembling the castellum at Semnah (...). Three small forts perched on isolated hills are situated at intervals extending over a mile up a wadi. The last of these overlooks a well beside which are remains of what may be the beginning of a long conduit or aqueduct down to the main enclosures. This small hill fort contains within its wall a high point from which all the other enclosures are visible." ${ }^{124}$

According to S. E. Sidebotham, Wadi Abu Qurayya was occupied, from the evidence of the surface ceramics, from the Ptolemaic period to late antiquity. ${ }^{125}$ The site is at $25 \mathrm{~km}$ from Berenike, which nicely fits with the 18 Roman miles indicated by the Antonine Itinerary

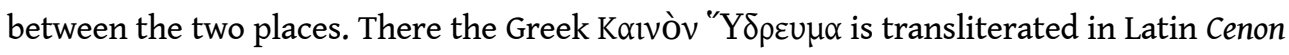
Hidreuma.

The question of the identification of Kalvòv "Y $\delta \rho \varepsilon u \mu \alpha$ has been embroiled by the mention, in Pliny, of a vetus hydreuma which has focussed scholars' attention, probably because of a mistranslation in the Loeb edition: mox ad Novum Hydreuma a Copto CCXXXVI. Est et aliud hydreuma vetus-Trogodyticum nominatur, ubi praesidium excubat deverticulo duum 
milium; distat a Novo Hydreumate VII. This passage should be understood as follows: "Then (one arrives) at New Well, at 236 miles from Coptos. There exists also another well, an old one, which is called 'Trogodytic,' where a garrison mounts guard, two miles off the main route. It is at a distance of 7 miles from Novum Hydreuma." In this text, it should be observed at first that hydreuma vetus is not a toponym. The toponym which Pliny attributes to this "old well" is Trogodyticum. It appears in no other source. Scholars are thus wrong to speak of a station which would have been called Vetus Hydreuma. Second, why did many scholars identify Wadi Abu Qurayya with "Vetus Hydreuma"? Because, I think, of the mistranslation in the Loeb edition, where it is understood that the garrison there consisted of two thousand men. Five forts were not too much to host this huge troop! But, if "Vetus Hydreuma" was identified with Wadi Abu Qurayya, Novum Hydreuma had to be placed elsewhere. On Meredith's map, it is situated at Wadi al-Kashir ( $24^{\circ} 11^{\prime} 03^{\prime \prime} \mathrm{N} / 35^{\circ} 14^{\prime}$ 05” E). Until recently, it was also Sidebotham's view. However, there is nothing there, except for what looks like a hafir, i.e. an oval levee of gravel meant to retain flood water. ${ }^{126}$ S.E. Sidebotham informs me that he now prefers to identify Novum Hydreuma with the tiny fort of Wadi Lahma (or Lahami, $24^{\circ} 09^{\prime} 55^{\prime \prime} \mathrm{N} / 35^{\circ} 21^{\prime}$ $55^{\prime \prime}$ E). ${ }^{127}$

Scholars who identify Wadi Abu Qurayya with the alleged Vetus Hydreuma are well aware that Wadi Abu Qurayya tallies, in terms of distance, with the Cenon Hidreuma of the Antonine Itinerary. It obliges them to imagine either that Pliny's New Well is another one than the Itinerary's, or that Novum Hydreuma and "Vetus Hydreuma" are one and the same site. ${ }^{128}$ As for the Plinian Trogodyticum Hydreuma, it remains a mystery.

\section{Praesidia surrounding Mons Claudianus}

Three names of praesidia, other than those that control the metalla of Claudianus and Tiberiane appear in the O.Claud. Raïma is by far the most represented, with approx. 90 occurrences; Kampe has 16 references, and Lakkos, only one which is certain.

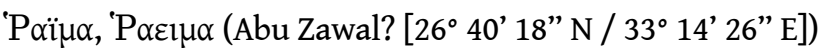

Both spellings are well represented: they are two different ways of rendering the diaeresis. The word normally does not inflect, but it exceptionally has an accusative

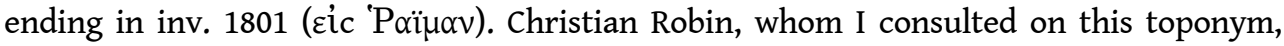
believes that a Semitic origin (specifically Arabic or Aramaic) is possible. I reproduce the note, dated 28/07/1994, with which he kindly provided me: "The RYM root is well attested in Arabic, see especially (dictionary Kazimirski):

raym: supplement; hill; tomb; white gazelle

rim: tomb; burial

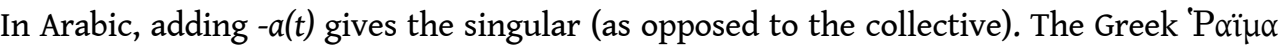
can, therefore, transcribe an Arabic word Rayma(t) whose meaning could be "hill," "tomb," etc. In Hebrew and Syriac, the correspondent of the root RYM is RWM, which can give derivative forms with a $\mathrm{Y}$ in place of $\mathrm{W}$ in Syriac (dictionary Payne Smith):

raymo': wild bull, buffalo, unicorn

reyomo': support

reyomto': very large stone, barrier

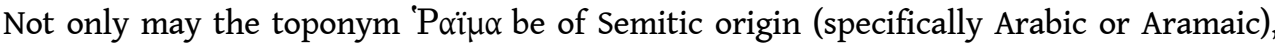
but it has a matching term in Yemen, and a rarer one in Saudi Arabia. In south Yemen, the repertoire of toponyms indicates four Rayma (People's Democratic Republic of Yemen. 
Official Standard Names. Prepared by the Defense Mapping Agency Topographic Center, Washington 1976, p. 165). In North Yemen, a less systematic repertoire gives seven. In Saudi Arabia, I note five Rìm, one ar-Rīmān, one Rìmān and one ar-Rayma. Rayma is a very common toponym in southern Arabia (but rarer in the Arabian desert)."

The many letters written by curators of Raïma to correspondents at Mons Claudianus (centurion, curator, oikonomos) show that Raïma was the first way station after Claudianus in the direction of the Nile and, conversely, the last station before Claudianus on the ódòc K $\lambda \alpha u \delta \_\alpha v o \tilde{v}$. These messages are often cover letters or receipts tracking the official letter. Raïma was not only an official relay station of the postal service, but also a stage where caravans and teams drawing wheeled vehicles stopped and drank. The praesidium must have had a well like many fortlets of the desert. It is possible that they had to build a second one nearby: this could be the <h>ydreuma which, writing from Raïma, Antistius Flaccus tells his colleague Caninius, who is at Mons Claudianus, about the successful drilling (O.Claud. I 2). They certainly did not wait until the reign of Trajan (date of the letter) to sink a well in Raïma, the name of which is restored with a fair degree of certainty on an ostracon of AD $68 .{ }^{129}$ This new well near Raïma may be the same as that referenced in the letters of Demetras 0.Claud. II 383 and IV 864: Demetras informs his correspondents that a stonecutter sent from Mons Claudianus was not present at the hydreuma, and, secondly, that baskets which should have been sent from Raïma to the hydreuma went off to Claudianus. Several curators' letters betray the fear of running out of water or are requests for equipment for the maintenance of shadufs (plural, $\kappa \eta ́ \lambda \omega v \varepsilon c$, $\kappa \eta \lambda \omega ́ v \varepsilon l \alpha:$ one for each well?). ${ }^{130}$

It comes as no surprise that Raïma has a vegetable garden ( $\kappa \tilde{\eta} \pi \circ)$, which allows the curator to send vegetables to the centurion stationed at Claudianus (O.Claud. II 370).

One would think that Raïma received its supplies from the valley, when the poreia went towards Claudianus, passing through Raïma. Yet we observe that Raïma's granaries are sometimes supplied from Claudianus (O.Claud. I 124 and 125: acknowledgments for loads of achyron [chaff] sent from Claudianus to Raïma by the caesarianus Successus; inv. 2188: acknowledgment to Philon for three artabai of bread). Raïma has a granary, and its manager ( $\theta \eta c \alpha \cup \rho \circ \varphi v ́ \lambda \alpha \xi)$ informs his counterpart in Claudianus that a carpenter collected his rations at Raïma (inv. 555).

The only major way station that could correspond to what we know about Raïma from this communication is Abu Zawal, ${ }^{131}$ c. $33 \mathrm{~km}$ walk from Claudianus. We owe to R. and D. Klemm the best description of this site, which was exploited as a gold mine under the New Empire and under the Ptolemies. ${ }^{132}$ According to their observations, Abu Zawal was only a station on the road to Claudianus in Roman times. They published a photo of an ostracon from the dump west of the fortlet, with a translation given to them by the late Georges Nachtergael. Here is the text, which I transcribe from the photo (Fig. 28): ${ }^{133}$

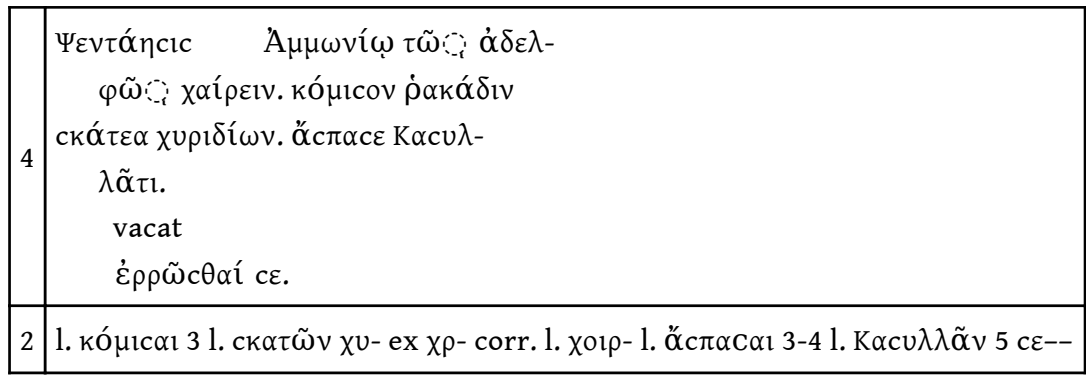


Psentaesis to Ammonios his brother, greetings. Take delivery of a rag containing pig manure. Greet Kasyllas. Farewell.

Fig. 28

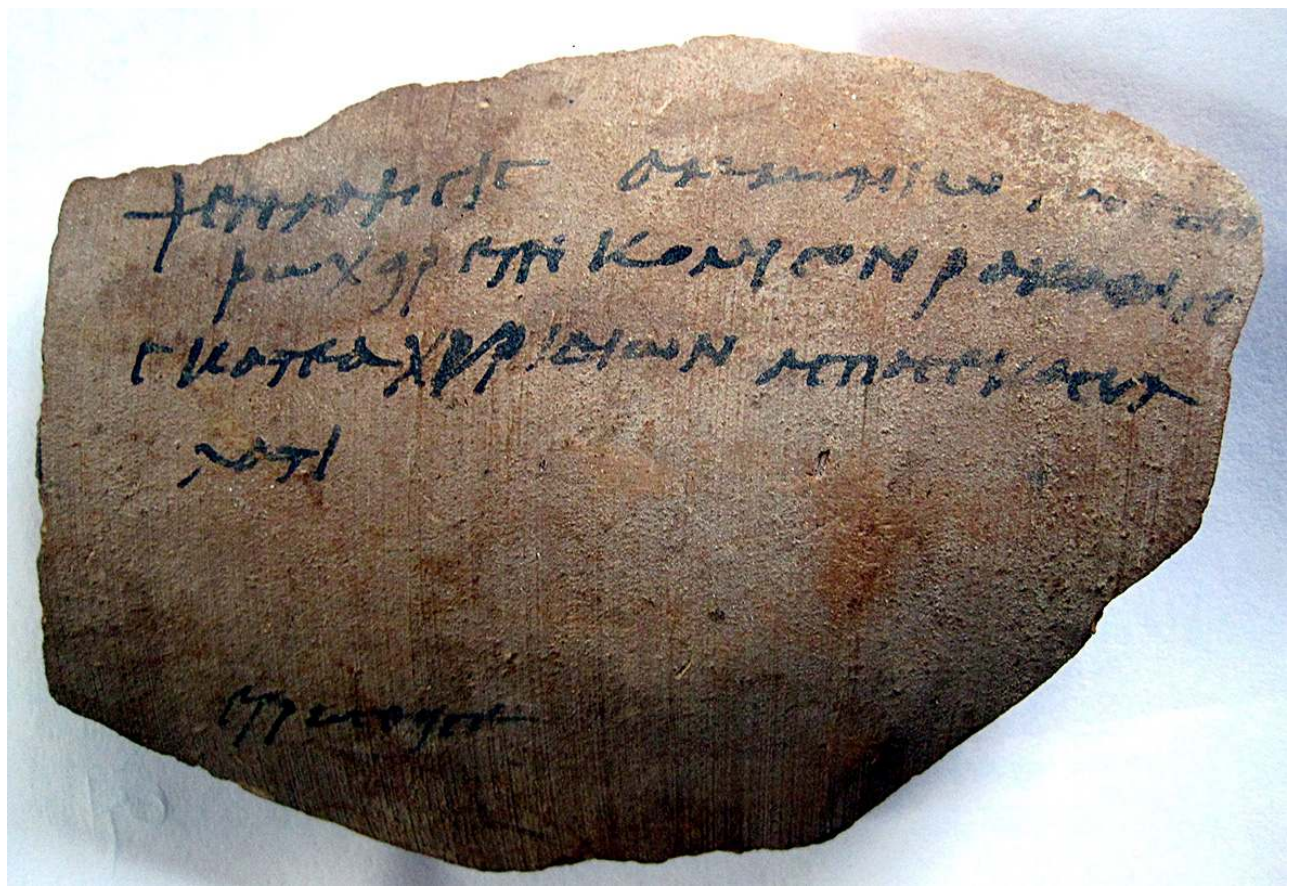

Ostracon found at Abu Zawal.

(c) R. KLEMM

The three people mentioned have, unfortunately, not been identified with individuals known from the Claudianus ostraca, whence the letter was probably sent. It could indirectly confirm the identification of Abu Zawal with Raïma. Not only did Raïma have a vegetable garden, but an ostracon from Mons Claudianus, O.Claud. II 280, a letter from a praesidium where market gardening is practised (it ends with the information, "vegetables have not grown yet"), ${ }^{134}$ accompanies the empty return of "the basket you sent us loaded with excrements, ${ }^{135}$ that you will return to us when you get the opportunity." The soiled basket could probably only serve for these contents thereafter in the comings and goings between Claudianus and Raïma. On the ostracon from Abu Zawal manure is not

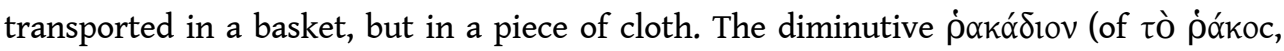
"rag") is only known from papyrological documentation, and nearly all the occurrences are found on ostraca from the Eastern Desert, where a $\dot{\rho} \alpha \alpha_{\alpha} \delta$ iov is for packaging up sticks of collyrium, dates and a tunic. ${ }^{136}$ The editor of 0.Claud. II 280 questions the nature of the fertilizer sent: the ostracon from Abu Zawal perhaps offers a response (and suggests additionally that there were no pigs at Raïma when this letter was written). It remains, nevertheless, curious that this gardener from Raïma is not happy with donkey or camel dung which must have been locally plentiful: did the pig waste have a special reputation? This is the case at least for the cultivation of certain fruit trees, according to

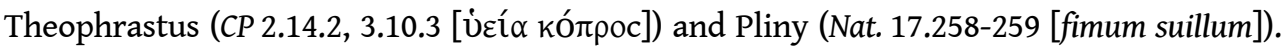
But there may be another hypothesis: this was not for fertilizer, but an ingredient for a medicinal preparation or magic potion, as in the letter O.Did.395, which contains the

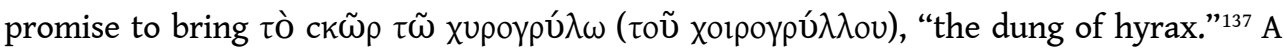


morphological argument could be made in favour of this hypothesis: the curious accusative plural ckó $\tau \varepsilon \alpha$ calls to mind a remark by Gignac on the non-contracted accusative plural - $\varepsilon \alpha$ instead of - $\eta$ neuter nouns ending in -oc (type $\gamma \varepsilon ́ v o c$, gen. $\gamma \varepsilon ́ v o u c)$ : accusative $-\varepsilon \alpha$ is found only in magical papyri. ${ }^{138}$ In fact, next to the classical form tò $c$

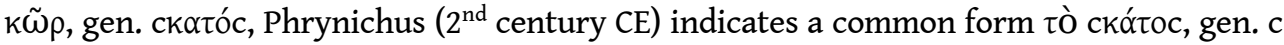
Kó́touc. ${ }^{139}$ It should be observed, however, that the pig is virtually the only domestic animal whose droppings are not widely advocated by ancient pharmacopoeia. ${ }^{140}$ Nevertheless, it is remarkable that none of the three ostraca from the Eastern Desert mentioning manure employs the usual term, which is кó recipes or when it refers to fertilizer.

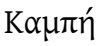

This praesidium ${ }^{141}$ is mentioned in sixteen ostraca, Trajanic and later, of Mons Claudianus. Its name seems to suggest that it was on a bend. This concept is common in toponymy. ${ }^{142}$

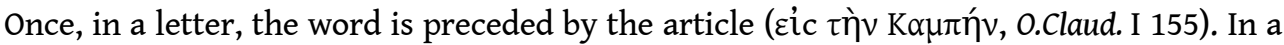

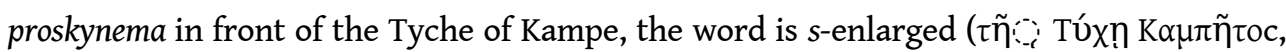
o.Claud. II 237, 5). Two letters addressed by curators of Raïma (presumably Abu Zawal) to curators of Claudianus acknowledge receipt of post sent from Claudianus and confirm that it has been forwarded at once to Kampe (O.Claud. inv. 7027 and 7595). It seems therefore that Kampe was a station beyond Raïma in the direction of the Nile. Hence three identifications are possible: (1) Kampe would be the station of Al-Saqiya on the road to Porphyrites; its name, "The Bend," would refer to the fact that one would turn off at Kampe towards Claudianus. Al-Saqiya ( $\left.26^{\circ} 44^{\prime} 04^{\prime \prime} \mathrm{N} / 32^{\circ} 52^{\prime} 54^{\prime \prime} \mathrm{E}\right)$ is at c. $38 \mathrm{~km}$ walk from Abu Zawal. (2) Kampe would be Tal'at al-Zarqa' ( $\left.26^{\circ} 35^{\prime} 09^{\prime \prime} \mathrm{N} / 33^{\circ} 11^{\prime} 56^{\prime \prime} \mathrm{E}\right)$. This site, which was never excavated, is called today Abu Shuwayhat by the Beduins; it comprises a well and animal-lines, and is situated at the entrance of the mountains, where a network of small valleys allows direct access to Abu Zawal (at least, it looks feasible on Google Earth for a pedestrian or a rider); the shortest way between the two sites is c. $11 \mathrm{~km}$. (3) Kampe would be Qarya ( $\left.26^{\circ} 22^{\prime} 16^{\prime \prime} \mathrm{N} / 33^{\circ} 01^{\prime} 08^{\prime \prime} \mathrm{E}\right)$. This praesidium, which can be seen behind the railway from the old Qena-Safaga road, is equipped with animal-lines. It may have been at the junction of the via Claudiana and the routes towards more southern sites, especially the Ophiates.

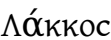

O.Claud. inv. 2283 (Trajanic?) suggests that Lakkos, the Cistern, is a praesidium, probably so called by metonymy, because it did not have a well, only a cistern that was filled thanks to the caravans of animals loaded with skins. The recipient of this wrathful letter, in

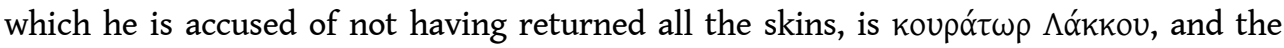
title curator is attested in the Eastern Desert for curatores praesidiorum only. The small praesidium at Mons Claudianus which, since Schweinfurt, has infelicitously been called "The Hydreuma," despite the fact that it has no well but only a cistern, might be a good candidate. Howewer, this identification is not confirmed by the ostraca found on the spot: the address of destination, when written on amphoras found at "The Hydreuma" is cic

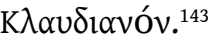

o.Claud. inv. 2283 is the only certain evidence of a praesidium called Lakkos. Among the other occurrences in the Claudianus corpus of the noun $\lambda$ ókкoc, I am tempted to believe that in O.Claud. IV 714 and 717 (Trajanic) this is also the praesidium because of its proximity to two other toponyms: in these lists, the last items are, in order: $\lambda \alpha \alpha_{k \kappa \omega}$ ( 


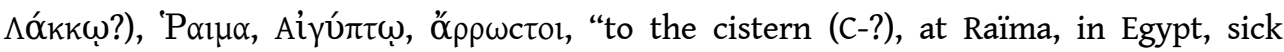
people."

\section{Praesidia surrounding Umm Balad}

\section{A. The field data}

Four fortified quadrangles exist within a radius of ten kilometers of Umm Balad. The most frequent names of praesidia in O.KaLa. necessarily refer at least to some of them. These four praesidia are:

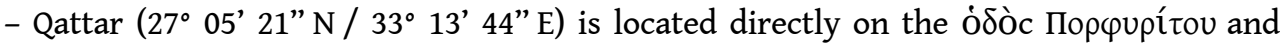
$9 \mathrm{~km}$ as the crow flies from Umm Balad, c. $11.5 \mathrm{~km}$ for a traveller. It is the immediate neighbour of Umm Balad in the direction of Qena / Kaine. ${ }^{144}$ As all the way-stations on the hodos Porphyritou (which Umm Balad is not), the praesidium of Qattar is flanked by animallines. All traces of the ancient well have disappeared: either it was inside the fort and was destroyed by the construction of modern wells, or it was outside and has silted up.

- Badiya ( $\left.27^{\circ} 12^{\prime} 52^{\prime \prime} \mathrm{N} / 33^{\circ} 20^{\prime} 42^{\prime \prime} \mathrm{E}\right)$ is at $9 \mathrm{~km}$ as the crow flies, $11.20 \mathrm{~km}$ drive from Umm Balad, and its immediate neighbour in the direction of Porphyrites. ${ }^{145}$ Like Umm

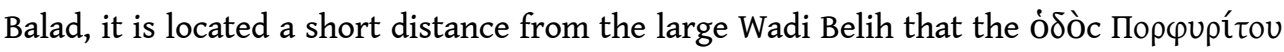
follows. The animal lines, which extend in front of the fort, show that it was an important stopping point for beasts of burden and draught animals coming or going to Porphyrites (see Fig. 29). From Badiya there were two routes to Porphyrites. Men and beasts could get to the "footpath station" at the foot of the mountain and pass through it by a zigzag trail on the hillside that led to Wadi Ma'mal and the administrative centre of the metallon. However, transport wagons that were to be loaded with monoliths at the main loading ramp (Fig. 29) would have followed a track skirting the massif of Jabal Dukkhan. This long detour route was mainly used for the monoliths coming down from Porphyrites. A few metres from the fortlet of Badiya rises a curiously fortified rocky hill. There is no well within the praesidium; the closest known well, Bi'r Badiya, still in use, is $500 \mathrm{~m}$ away; it is not possible to know whether it is the ancient well. A nearby well, that is unknown today, may have supplied the occupants of the fortlet.

- The "footpath station" $\left(27^{\circ} 13^{\prime} 03^{\prime \prime} \mathrm{N} / 33^{\circ} 18^{\prime} 25^{\prime \prime} \mathrm{E}\right)$ is a tiny fort $8 \mathrm{~km}$ from Umm Balad as the crow flies, on a shortcut to Wadi Ma'mal where the administrative centre of Porphyrites was. ${ }^{146}$ This winding route ${ }^{147}$ allowed quicker access to Wadi Ma'mal for human and animal pedestrian traffic ${ }^{148}$ than that via Wadi Umm Sidri, which wheeled vehicles would have used (Fig. 29). It is unclear whether camels could use it or not. ${ }^{149}$ The satellite image shows that one could join this fort from Umm Balad bypassing Badiya, but we did not have time to explore exactly which route the ancients took. I believe, from the image, that this route was about $12 \mathrm{~km}$.

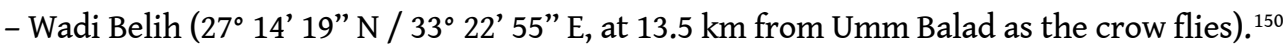
This is a small praesidium with an atypical plan, seemingly devoid of an inner well, located in the estuary of Wadi Belih. It was, therefore, at the entrance (for traffic from the Red Sea) of the diagonal connecting Porphyrites and, later, the fort of Abu Sha'r to Qena/ Kaine across the Arabic chain, with Wadi Belih continuing into Wadi al-Atrash. Was the fortlet used to control the entry of the route to the Nile? Was it a way-station on the via Hadriana? ${ }^{151}$ It was one kilometre away from the heavy-loads route to the Porphyrites, which went through Badiya. ${ }^{152}$ From Wadi Belih one could reach Badiya by walking just 
over $5 \mathrm{~km}$. Wadi Belih has never been excavated; it has been dated from the surface ceramics to the first and second centuries CE. ${ }^{153}$.

Fig. 29

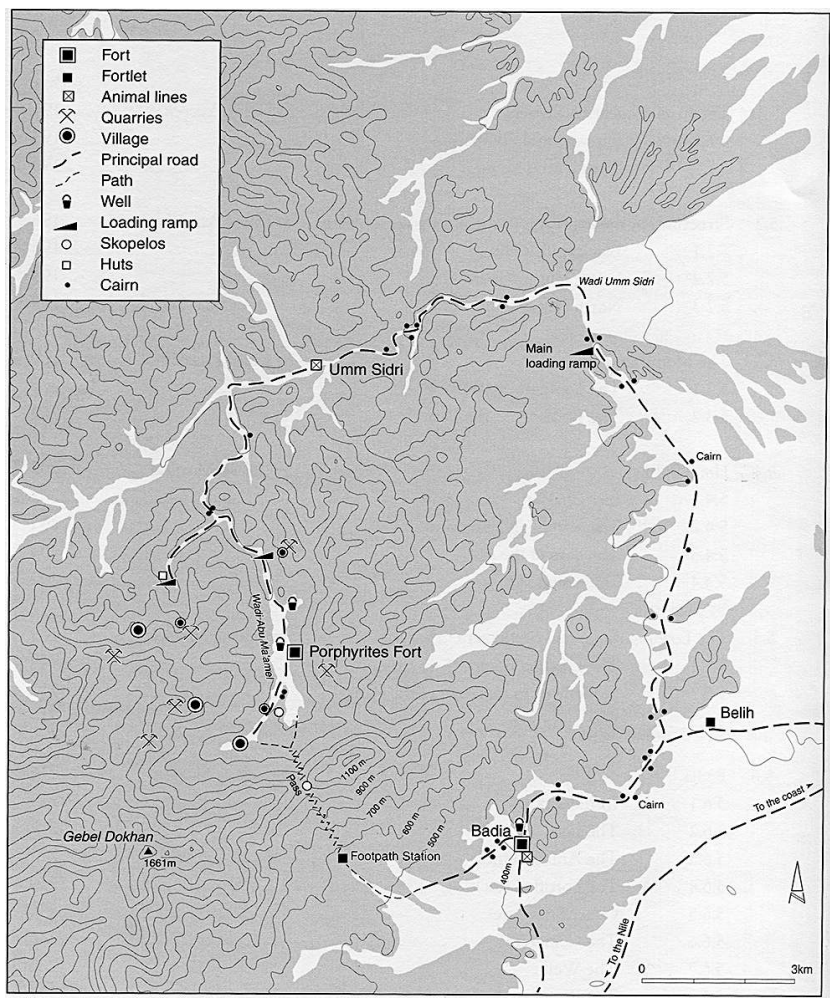

Tracks to Porphyrites, according to Maxfield, Peacock 2001, p. 194. The wells identified are reported.

(C) S. GODDARD

In the following table all the toponyms in the Umm Balad corpus are presented. A site is characterized as a praesidium when under the command of a curator or when the generic praesidium is attached to the specific. Names of metalla have already been studied; those of wells are in the section on hydreumata.

Table 4

\begin{tabular}{|c|c|c|c|}
\hline & topographic object & Number of occurrences ${ }^{154}$ & Of which number of tituli \\
\hline Kaine Latomia & metallon + praesidium & 102 & 93 \\
\hline Domitiane & metallon + praesidium & 43 & 31 \\
\hline Porphyrites & metallon + praesidium & 36 & 5 \\
\hline Claudianus & metallon + praesidium & 6 & 0 \\
\hline Prasou & praesidium + well & 29 & 2 \\
\hline Sabelbi & praesidium + well & 22 & 6 \\
\hline Akantha & praesidium & 10 & 0 \\
\hline
\end{tabular}




\begin{tabular}{|l|l|l|l|}
\hline Kardameton & well & 7 & 0 \\
\hline Arabarches & metallon? & 4 & 1 \\
\hline Germanike Latomia & metallon & 1 & 0 \\
\hline Melan Oros & praesidium & 5 & 1 \\
\hline
\end{tabular}

THE TOPONYMS MENTIONED IN THE OSTRACA FROM UMM BALAD.

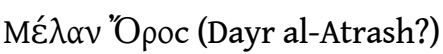

Among the praesidia mentioned in the ostraca from Umm Balad, Melan Oros has the fewest references: five in all. So it was probably the farthest away. Yet, its identification seems the soundest. Two of these occurrences clearly demonstrate that Melan Oros was between Umm Balad and the Nile Valley. In O.KaLa. inv. 637, the soldier Marcus Ares Verus, stationed at Melan Oros, promises to send vegetables to the Chief Doctor at Umm Balad "when the steward for the provisions for soldiers comes (sc. from the valley)." In O.KaLa. inv. 275, Antistius, short of bread, asks his correspondent Antonius, who is at Umm Balad, to send him some on the next poreia: we understand that when the supply caravan comes from the valley, Antistius will receive his bread ration and will take a portion that he will resend on the poreia so that it gets to Umm Balad, for Antonius. To reassure Antonius of a quick refund, Antistius added this encouraging information, "they

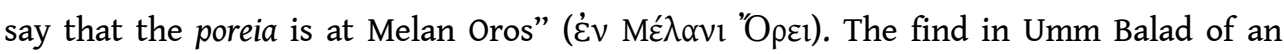
amphora titulus mentioning the destination of Mé $\lambda \alpha v$ 'O$\rho \circ[c]$ could be explained by a similar arrangement. ${ }^{155}$

The demand for bread suggests that there is at least one praesidium (the one where Antistius is stationed) between Umm Balad and Melan Oros. As Melan Oros cannot be far away, it is tempting to identify it as Dayr al-Atrash, Antistius being then stationed at Qattar.

MÉ $\lambda \alpha v$ "Opoc is once followed by the generic: a soldier is described in a draft of a letter as

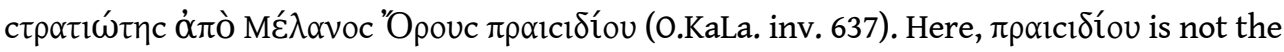
third element of a complex toponym, but an apposition.

It is tempting to identify the praesidium of the Black Mountain as that of the Black Stone

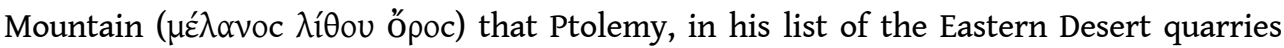
Geogr. 4.5.27, 156 inserted between the mountain of porphyry and the mountain of basanites (i.e. greywacke quarries of the Wadi al-Hammamat). ${ }^{157}$ The editors of the Geography, including Müller, do not provide an identification.

164 Пра́cov (Badiya or Qattar?)

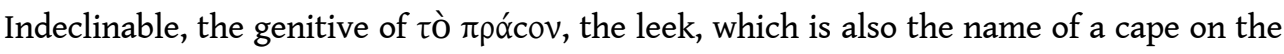
eastern coast of the African continent, mentioned several times by Ptolemy (

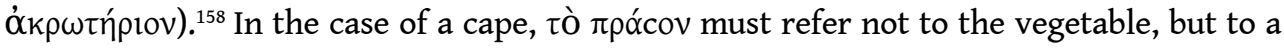
seaweed, posidonia.

165 According to letters sent to Umm Balad, this praesidium had a well, a cistern and a vegetable garden. As it seems to be an immediate neighbour of Umm Balad, it must be Badiya or Qattar, but the content of the letters does not allow us to be sure. 
Abundantly attested in the ostraca of Umm Balad, Prasou may be mentioned in O.Claud. inv. 3438 (Trajanic), a fragmentary letter in which Epagathos asks Geta to send him something related to cavalry men; line 4 reads: غ̇v חрócou $\pi[$.

This site, which has 22 occurrences in ostraca from Umm Balad, cannot be far away. The existence of a curator of Sabelbi guarantees that it is a praesidium. Letter O.KaLa. inv. 266 is particularly informative: its author, Paulinus, asks his correspondent to send three men as reinforcements to clean out the well at Sabelbi so that the wagon will have water when it returns from Porphyrites. It is, therefore, tempting to assume that Sabelbi can be identified with Badiya (for another argument in favour of Badiya, see $\$ 167$ ), However, Qattar cannot be ruled out: would not the wagon returning from Porphyrites need water not only from Badiya, but also from Qattar? A. Bülow-Jacobsen, however, cites O.KaLa. inv. 422 to support the second hypothesis: ${ }^{159}$ Hieronymos addresses this letter to Maximus, stationed in Umm Balad, asking him to send ropes "so that the wagon can hold

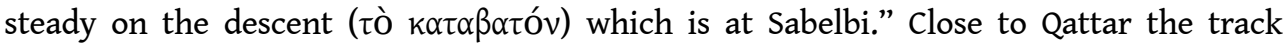

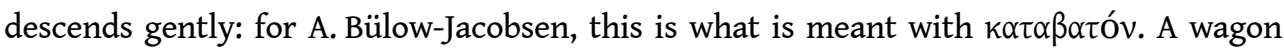
carrying a monolith must have stopped at the top of this slope, waiting for the ropes to retain it.

The spelling of this enigmatic place name varies: $C_{\alpha \beta \varepsilon} \lambda \beta_{1} \alpha$ (O.KaLa. inv. 697), $C_{\varepsilon} \beta 1 \lambda \beta 1 \alpha$ (accusative $C \varepsilon \beta 1 \lambda \beta 1 \alpha v$ ) in O.KaLa. inv. 208 and 564 (although in this case, the palaeography suggests rather $C \alpha \beta \varepsilon \lambda \beta \lambda \lambda), C \alpha \beta \alpha \lambda[$ (0.KaLa. inv. 541). I have found only two foreign names with a similarity to $C \alpha \beta \varepsilon \lambda \beta \mathrm{l}$ : the Libyan name $T \alpha \beta \alpha \lambda \beta \mathrm{rc}^{160}$ and the name of the Mysian C $\tau \alpha \beta \varepsilon \dot{\lambda} \beta_{\text {loc }}$ in Aristotle's Economics (1353b). Cornelia Römer suggested to me a comparison with the Arabic sabil.

'A $\alpha \alpha v \theta \alpha$

The existence of a curator of Akantha, the author of a letter sent to a centurion residing in Umm Balad, ${ }^{161}$ seems sufficient to consider that this site, probably named after a remarkable acacia, either due to its isolation, or size, had the status of a praesidium. The moderate number of occurrences suggests that Akantha is either relatively far from Umm Balad (but perhaps not as far as Melan Oros), or off the road to Porphyrites. In reality, it cannot be very far: the purpose of the curator's letter is, in fact, to complain about a certain Amais, posted at Umm Balad, who refused to send his rations to a certain Mithron stationed at Akantha. Mithron is forced to go to Umm Balad to pick them up, probably with the letter from his curator. Akantha may not be a stop for the poreia, the supply caravan.

Three letters date from the Domitianic-Trajanic phase of Umm Balad, which are requests to the authorities of Umm Balad (a centurion, the curator, the architect Hieronymos) ${ }^{162}$ to order the garrison at Sabelbi to send a cavalryman to escort a camel going to Akantha, so that it will not be going alone. Akantha seems, thus, to be a remote site accessed via Sabelbi. If Sabelbi is to be identified with Badiya, then Akantha could be either the footpath station or the fortlet of Wadi Belih. Two of these requests come from Turranius, who I think is curator at Prasou. ${ }^{163}$ On the other hand, I do not see which praesidium Akantha could be if one identifies Sabelbi with Qattar, unless Akantha is the same site as the well of Akanthion (once called 'A $\alpha \alpha v \theta \alpha$ ) mentioned in the ostraca from Mons Claudianus and the eponym of a road. ${ }^{164}$ Is there a road linking Claudianus to the region of Umm Balad? The possibility of such a route exists: after crossing the sand-sea that 
spreads NW of Claudianus, one enters the mountains, then bears SW towards Umm Shejilat ( $\left.26^{\circ} 56^{\prime} 36^{\prime \prime} \mathrm{N} / 33^{\circ} 14^{\prime} 53^{\prime \prime} \mathrm{E}\right) ; 1.5 \mathrm{~km}$ NE of this little quarry, one follows up a NS wadi towards Qattar. There Meredith's map has a well called Bi'r Umm Disi, invisible on the satellite photo. However, I do not think that this discreet well could be the remnants of the Akantha of O.Claud. and O.KaLa. In the O.Claud., the Akantha provides water for Mons Claudianus (\$179): Bi'r Umm Disi is too far away for that. On the other hand, the Akantha in the O.KaLa. is under the command of a curator: it must have been a fortified well, in other words a praesidium, which would have left traces. Akantha still exists in the third century: it is mentioned in several of the ten letters of the small archive of the centurion Caninius Dionysios, who seems to have had a short-lived stay in the praesidium of Umm Balad at the time.

'Ak $\alpha v \theta \alpha$ inflects. Unlike for the well named tò Akóv $\theta 1$ เov in O.Claud., the use of the article in front of 'Ak $\alpha v \theta \alpha$ is variable and appears to depend on individuals or perhaps the date. ${ }^{165}$ Turranius, author of many letters during the first phase of Umm Balad, uses the article, which is absent in three letters (of two different writers) from the $3^{\text {rd }}$ century archive of Caninius Dionysios.

\section{Conclusion on the toponymy of the praesidia}

Among the names of Greek and Latin praesidia, some are declinable, others are fixed in the genitive; these are underlined in the table below:

Table 5

\begin{tabular}{|c|c|c|}
\hline & noun & adjective \\
\hline appellative & 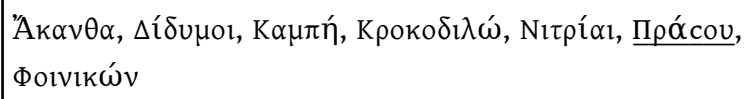 & 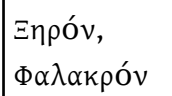 \\
\hline $\begin{array}{l}2 \text { appellatives (noun }+ \\
\text { adjective) }\end{array}$ & 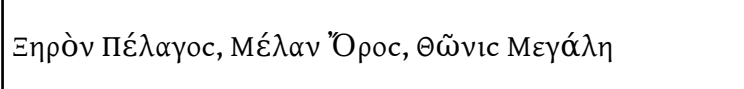 & \\
\hline proprial & 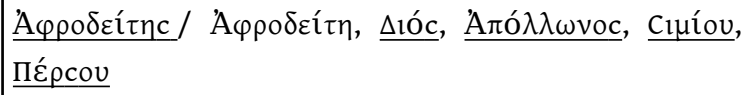 & M $\alpha \xi ı \iota \alpha v o ́ v$ \\
\hline
\end{tabular}

Names of the praesidia

It appears from this table that the names of praesidia which remain in the genitive are proprial names (theonyms and anthroponyms), Прớcou being the exception. In the case of Aтó $\lambda \lambda \omega v o c$, the fossilization of the genitive comes from the abbreviation of

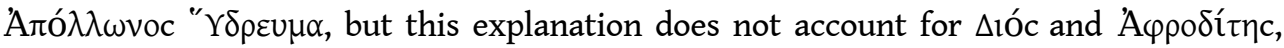
where it is known that the praesidium was not founded on the site of an old well whose compound name would have been retained. These genitives are, therefore, understood as complements to the term $\pi \rho \alpha ı c i ́ \delta ı v$ even if this noun, unlike v̌ $\delta \rho \varepsilon u \mu \alpha$, is practically never used as generic constituent in a complex toponym (\$162).

In three cases, the names of praesidia are unique adjectives. M $\alpha \xi \mu \imath \alpha v o ́ v$, a proprial

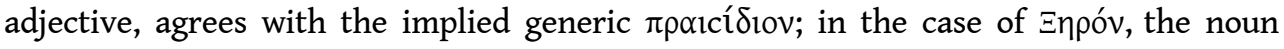

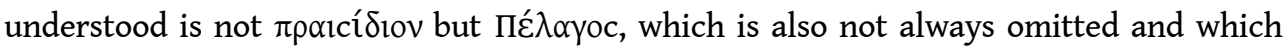


has the distinction of being a generic element "transferred," i.e. referring to a another

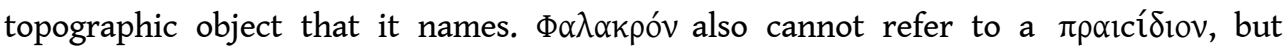
probably to a noun meaning "mountain;" so this is probably another example of transferred generics, but always omitted, at least in the documentation that we have.

\section{Wells (hydreumata)}

Misled by the text of Pliny and some complex toponyms which include the generic

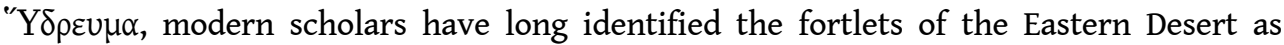
hydreumata, from where, for example, comes the unfortunate name "the Hydreuma" for the small fort of Mons Claudianus, although it has no well ( $\$ 156)$, as it was long believed that hydreuma meant any water point, whether it was a well or a tank. This is not so: the ostraca of the Eastern Desert have shown that this term, peculiar to Greek spoken in

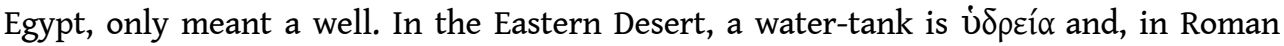
times, $\lambda$ ókкос.

The hydreumata listed below are isolated wells, not integrated in any praesidium. In the ostraca from Umm Balad, a single well (which has not been identified in the field) seems

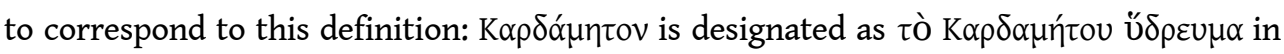
O.KaLa. inv. 747. This name is found in four ostraca. It is a hybrid, made from the Greek

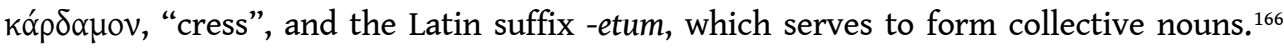

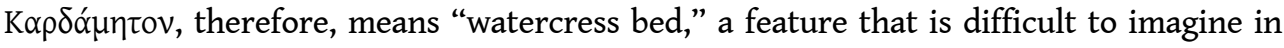

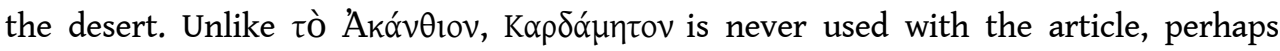

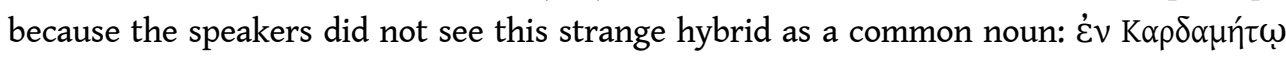

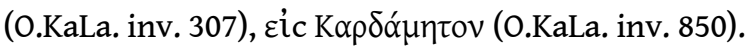

All other hydreumata addressed in this section are mentioned in ostraca from Mons Claudianus, with one exception, that we can no longer locate. One of them was perhaps the well of Wadi Umm Diqal, ${ }^{167}$ located in the middle of a quadrangle, which is $3.4 \mathrm{~km}$ from the praesidium of the Wadi Umm Husayn, when one uses the way that passes in front of the "Hydreuma." The exception is the Hydreuma Traianon Dakikon, which was sunk at the time of Trajan, a few metres west of the praesidium of the Wadi Umm Husayn. This honorary toponym (the only one in our corpus) is known from two inscriptions:

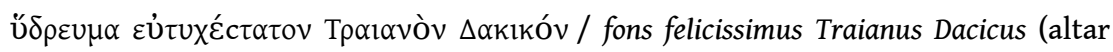
I.Pan 37, AD 108/109)

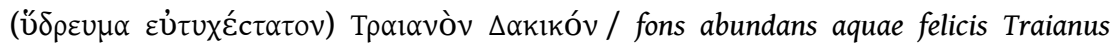
Dacicus (lintel in the room of cisterns, SEG XLII 1574)

These inscriptions were probably engraved for the inauguration of the well by the prefect Sulpicius Similis who came in person. The altar-inscription, on the podium of the Serapeum, has been known for long, but has now been destroyed. The other text is engraved on the lintel of the door of the cistern room, and was discovered during the 1991 season inside the praesidium (Fig. 30). Jean Bingen, the editor of the lintel inscription, considers Tpaı vòv $\Delta \alpha$ kıкóv/Traianus Dacicus as the name of the well, to the exclusion of

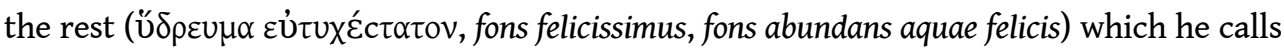
a "qualification". ${ }^{168}$ The structure of this toponym, however, is not unusual: generic ( ü $\rho \rho \varepsilon \mu \alpha /$ fons), followed by an accumulation of specifics with a variant in Latin. For lack

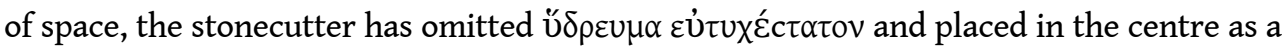
common factor fons abundans aquae felicis, while the last two specifics expressing loyalty 
to the emperor were arranged on both sides in Latin and Greek. It is possible that this cumbersome toponym, that was not in common use, refers, through metonymy, to the whole settlement of Wadi Umm Husayn. This would explain why neither of the inscriptions were found next to the well proper. In the third century $\mathrm{BC}$, another wellstation of the Eastern Desert combines the idea of good luck with a dynastic name: tò Apc

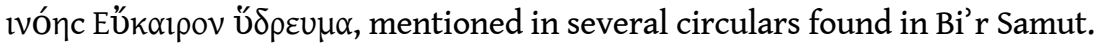

Fig. 30

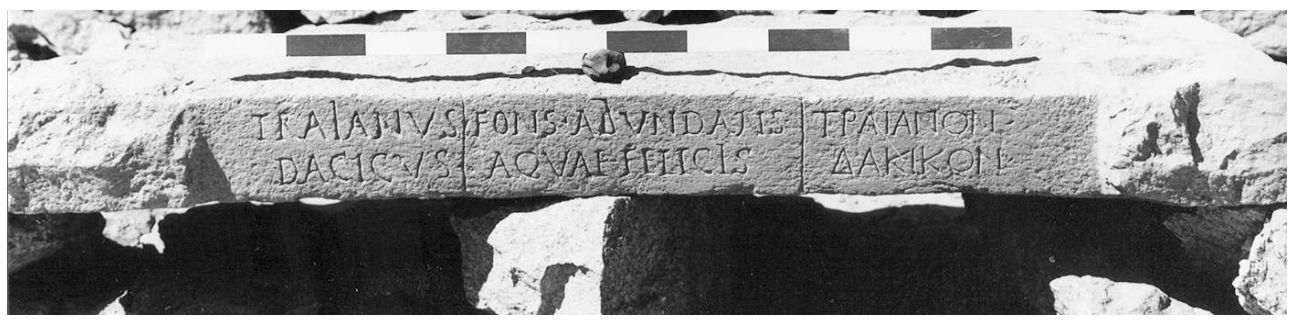

The lintel of the room of cisterns at Mons Claudianus.

(c) ADAM BÜLOW-JACOBSEN

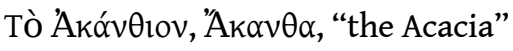

Several Trajanic ostraca from Mons Claudianus mention a well, where trains of camels went to fetch water, normally called tò Akóv $\theta$ เov (always with the article), and once, in a

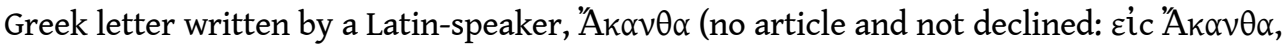
o.Claud. II 362). The money account O.Claud. inv. 3819 ends with the order: ع́pxov ic tò

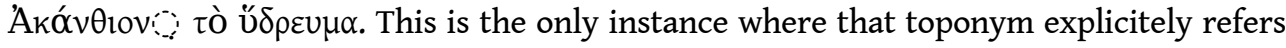
to a well.

A road was called after this well, according to two passes sent to stationarii / epiteretai [

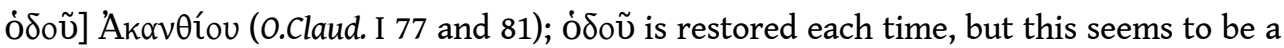
necessary restoration. It must be a secondary path leading from Claudianus to this well.

The well of Dioskoureia

The letter O.Claud. inv. 490 concerns a case of a diverted waterskin, in which "the men at

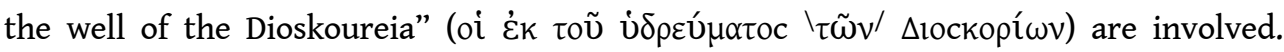
According to this ostracon, water was transported from this well to water the horses accompanying the poreia, i.e. the caravan periodically provisioning the metallon. The toponym is also attested in the great Trajanic water-chart ${ }^{169}$, where it appears among the

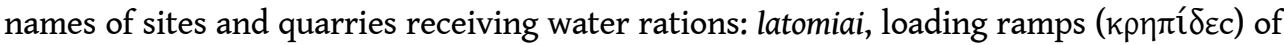

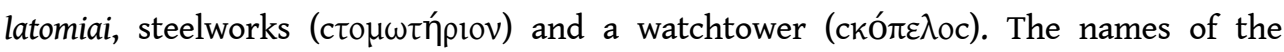
supplied sites are in the dative, and so is $\Delta$ lockopíorc, which probably refers to the hydreuma of the Dioskoureia in the letter, but as water is sent there, the well must be under construction. A further probable instance of the toponym appears in O.Claud. inv. 7955.

O.Claud.inv. 7955 (Fig. 31)

Trajan

Well - S1 C-W $4 \quad 8 \times 6,5 \mathrm{~cm} \quad$ Nile silt clay

Upper right corner of a letter, perhaps unfinished, written by an anonymous curator who broke off when he saw an error in the prescript, for which we do not have a similar

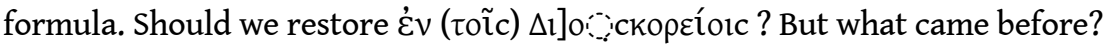

$\downarrow \quad$ ]c кoupó́ $\omega$ ○

vac.

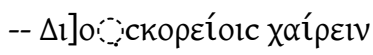




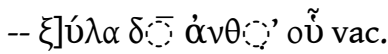

] $v a c$.

Fig. 31

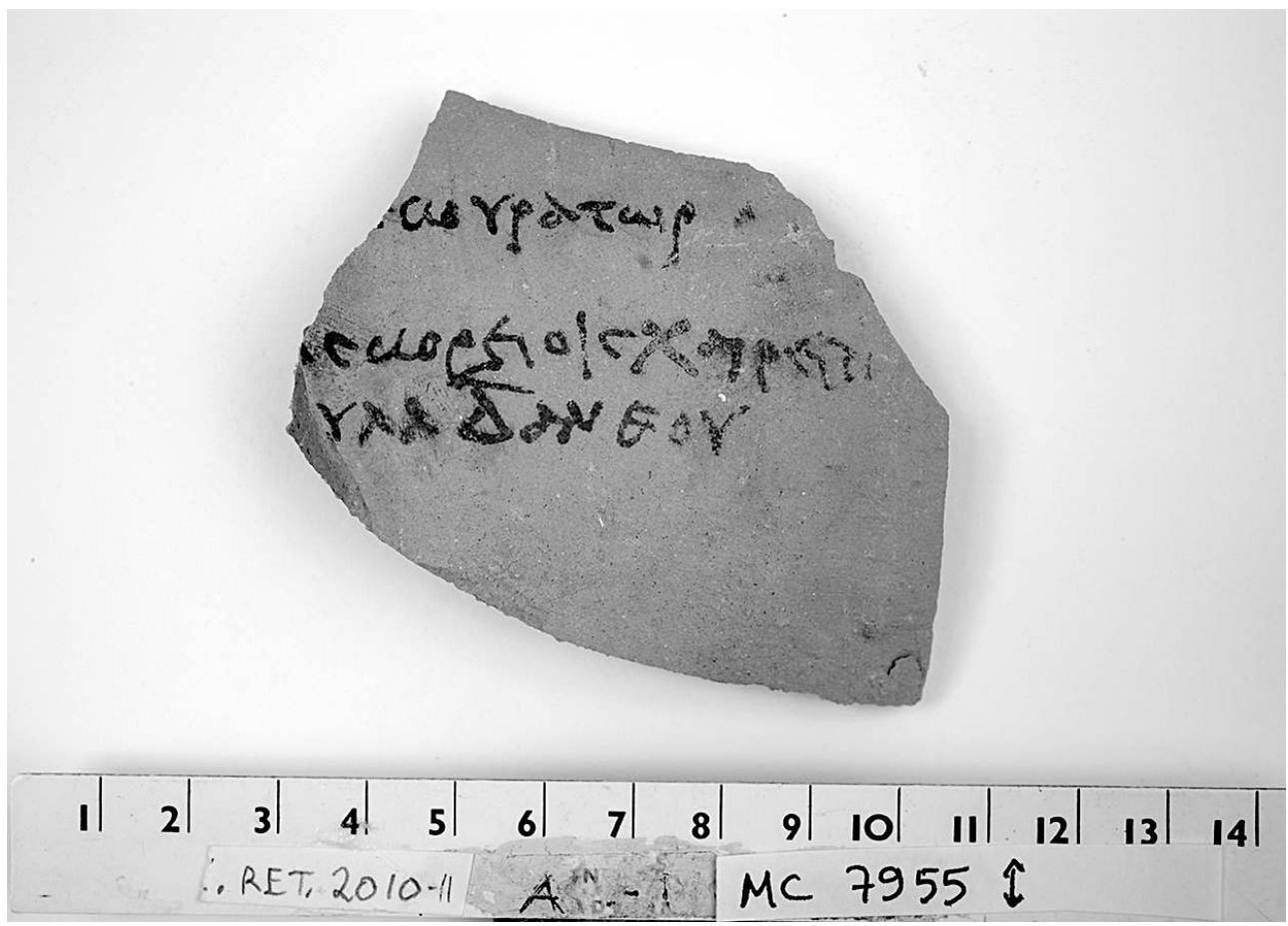

O.Claud. inv. 7955.

(C) ADAM BÜLOW-JACOBSEN

Katríou, the well of Cattius

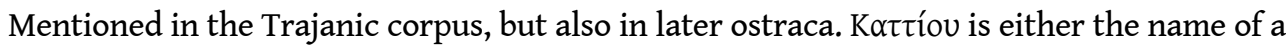
well, or rather perhaps that of a sector of a metallon where there was also a well. Besides

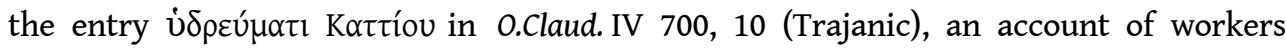
broken down by assignments, and O.Claud. inv. 3114, where Kattiou is a place whence

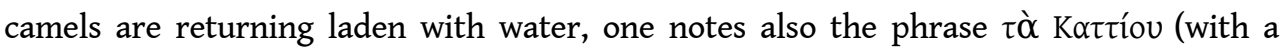

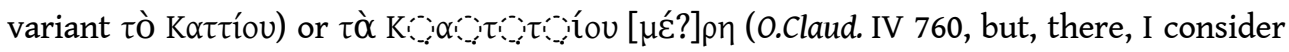
the dotted letters as uncertain, as well as the restoration). Kattiou is also a place to which

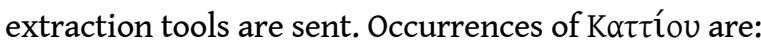

O.Claud. IV 697, 8 (Trajanic): account of workers broken down according to place or kind

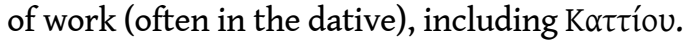

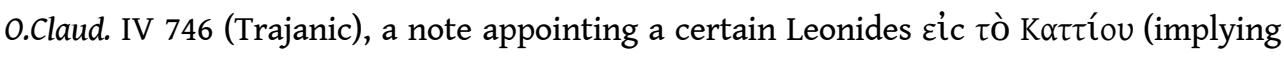
v̌ $\rho \rho \varepsilon \mu \alpha ?)$.

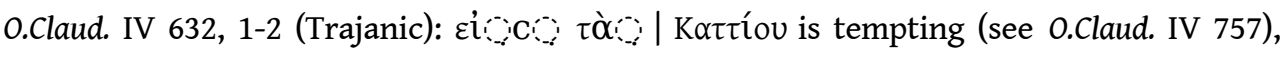

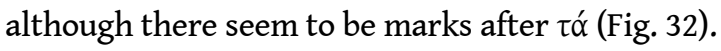




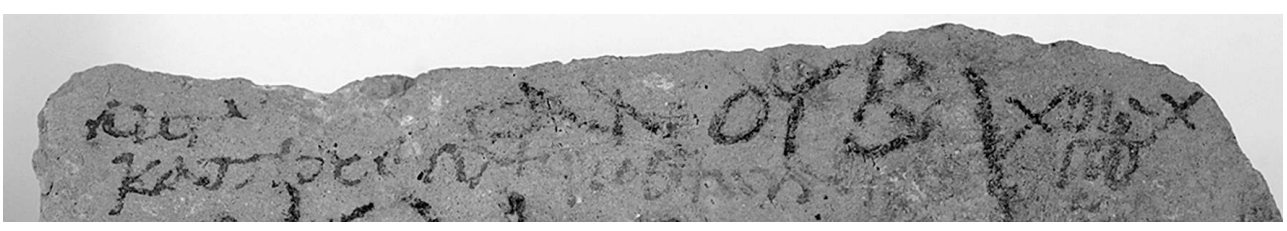

O.CLAUD. IV 632, 1-2.

(C) ADAM BÜLOW-JACOBSEN

O.Claud. inv. 2853, 1 (Trajanic): water-chart of the same series as the inv. 1538. The first section, which concerns blacksmiths' rations distributed to various stations, includes [the

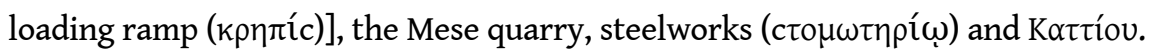

O.Claud. inv. 3114 (Trajanic): report on the movements of water-transport camels; 76 camels, loaded with water, came from Kattiou.

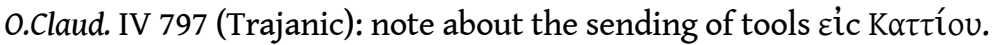

o.Claud. inv. 3342 (Trajanic), acknowledgment for a skin; the ticket written in charcoal

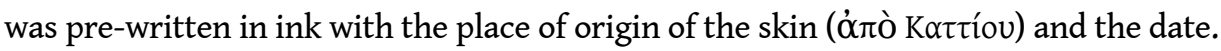

0.Claud. IV 757 belongs to a series of daily activity reports (Antonine); on that day, $1^{\text {st }}$ Epeiph, workers cleaned the trench of the column which was being extracted in Kattiou's

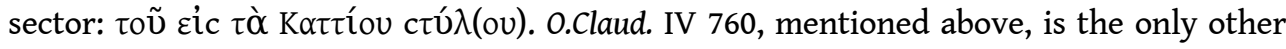

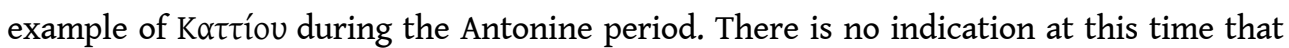
the well was still working.

The topographic feature which Kattiou refers to is not clear. Used on its own, could

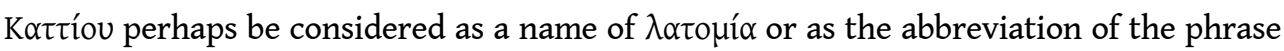

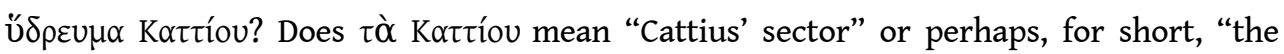
sector (of the well) of Cattius"? Because the names of the other wells are not drawn from

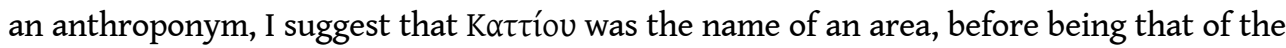
well drilled there.

\section{C $\alpha \lambda \alpha \varepsilon 1 c$}

This name, possibly Semitic and indeclinable (zic C $\alpha \lambda \alpha \varepsilon i c, \alpha \dot{\alpha}$ ò $C \alpha \lambda \alpha \varepsilon 1 c)$ is only attested

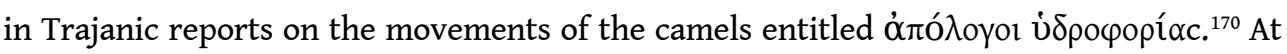
Salaeis, there was a well where camels were sent to fetch water.

\section{Conclusion on the toponymy of wells}

None of the names of these peripheral wells is a complex toponym with the

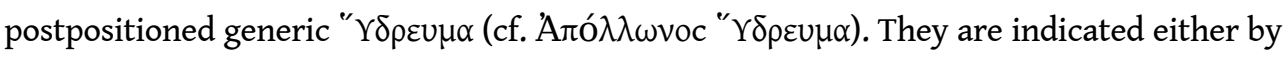

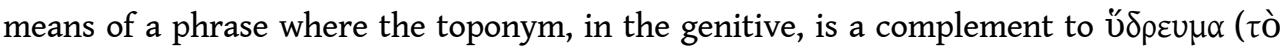

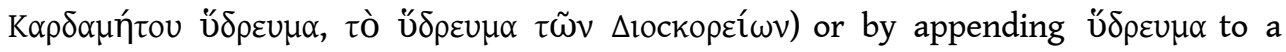
toponym, the use of articles following the rules of apposition ( cf. § 21). If they are used without ú $\delta \varepsilon v \mu \alpha$, the well names are declinable, except the one

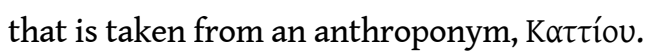




\section{Roads}

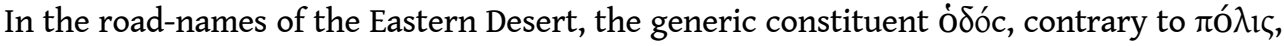

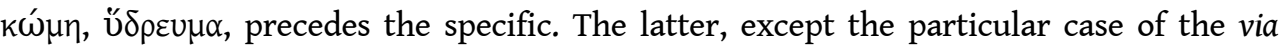
Hadriana, is either the name of the terminal of a road in the genitive (usually its destination from a reference point situated in the valley), ${ }^{171}$ or a proprial adjective derived from that name. In the first case, ódóc is followed by the name in the genitive of the metallon or seaport. The second case conforms to Latin usage, where the use of an adjective is preferred when forming a complex toponym which contains a generic. ${ }^{172}$

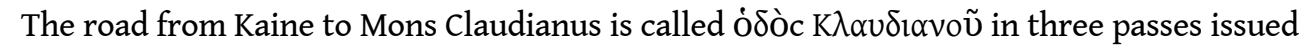

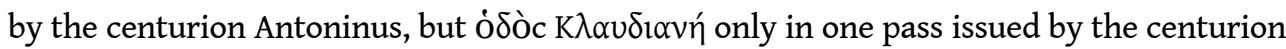
Accius Optatus.

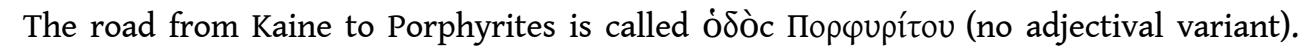

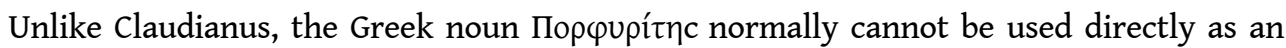

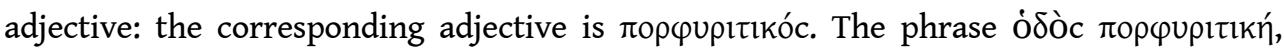

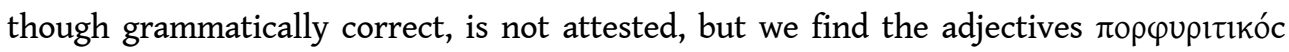

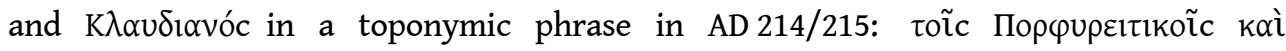

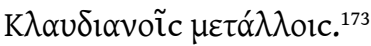

The road from Koptos to Myos Hormos is sometimes called ódòc Mucópuov, sometimes

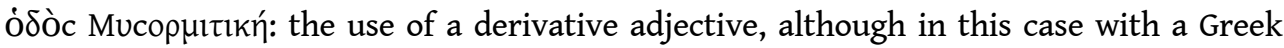
suffix, perhaps betrays the Latin influence.

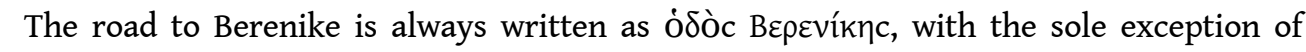

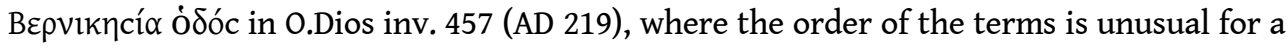
road-name. The suffix -ńcioc serves to transpose into Greek the situative Latin suffix ensis. This suggests that, in Latin, the road was called via Berenicensis.

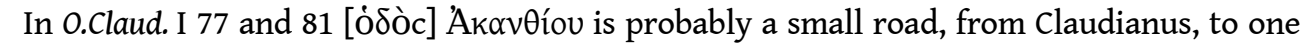
of the wells on which it depended for its water supply, the Akanthion ( $\$ 179$ ).

The Latin name of via Hadriana was formed in the Medieval period using the only evidence of this toponym, which appears only in Greek in the dedication of this road, inscribed on

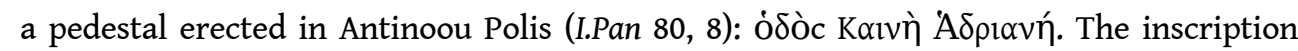
shows that, in the mental representation of the developers of the via Hadriana, the orientation of the road was reversed compared to other roads of the Eastern Desert, since

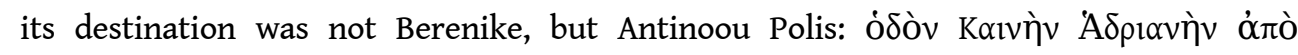

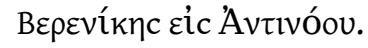

\section{Ports of the Red Sea}

\section{Berenike, Berenicis and Mons Berenicidis}

The southernmost area of the Egyptian Eastern Desert took the name Desert of Berenike in about $4 \mathrm{BC}$, once the Romans had revived the Ptolemaic port of Berenike and built a new road from Koptos to that port. The term "Desert of Berenike" is abundantly attested.

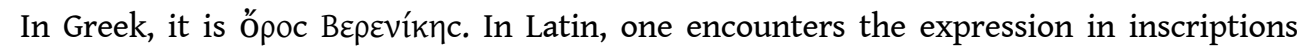
mentioning the Prefect of Berenike and we see that the name of the city was then, with 
one exception, suffixed by -is. We find once praefectus praesidiorum et montis Beronices, but three times praefectus Montis Berenicidis or simply praefectus Berenicidis. There is also the ablative Berenicide in the large inscription from Koptos commemorating the construction of water-tanks by the army (ILS 2483= I.Portes 56). ${ }^{174}$ However, the port of Bepevíkn on the Red Sea was never called Bepevikíc in Greek. There is a parallel phenomenon with Bepevík $\eta$ in Cyrenaica, which is called Berenicis in the Pharsalia of Lucan (9.524) and in the Punica of Silius Italicus (3.249). ${ }^{175}$ Editors justify this discrepancy considering that Berenicis

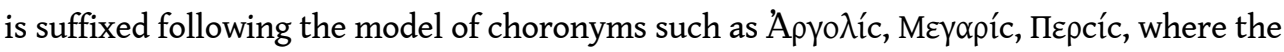
generic $\gamma \tilde{\eta}$ or $\chi \omega ́ p \alpha$ is elided. ${ }^{176}$ The suffix -is would mean that the referent is not the city alone, but the city and its chora. I admit that it would provide a very satisfactory solution in the case of the title praefectus Berenicidis. This is probably the reason why F. De Romanis interpreted the toponym Berenicis as a choronym in Latin inscriptions, which leads him to consider that the inscription ILS 2483 refers to the construction of a well in Berenicis (i.e. the region of Berenike), and that this well is Kalvòv "Y $\delta \rho \varepsilon u \mu \alpha$, which is $25 \mathrm{~km}$ above Berenike. ${ }^{177}$

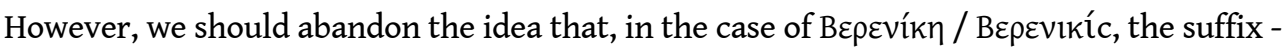
íc denotes a choronym. In the Peutinger Table and Ravenna Cosmography, Berenicide clearly designates the end point of the road, not a region, and corresponds to Berenike in the Antonine Itinerary, which is more faithful to the Greek usage. Two toponyms of Arsinoïte,

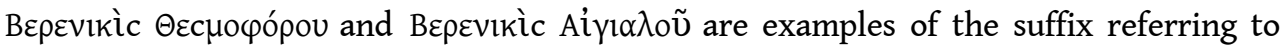
simple villages, and not to districts. Therefore, it appears that, when -íc is added to a dynastic anthroponym, it is to characterize it as a toponym, not to designate a region. The example of the two villages shows that when a settlement was called after a Queen Berenike, the naming authorities had the option of keeping the name unchanged, or of adding a suffix to emphasize that this was a toponym. ${ }^{178}$ In the case of the port of Berenike, there was a degree of fluctuation in Latin, but not in Greek. Frédérique Biville, whom I consulted on this Latin initiative to add a Greek suffix to a Greek base where the Greek model never appears to have a suffix, replied: "It is not surprising, I think, that there were Latin-speakers who felt the need to over-characterize the name Berenike: we also see that there is what could be called 'the Greek of the Romans', Greek forms and words created by the Romans, which are only documented in a Greco-Roman context."179

In the Greek and Latin names of the Desert of Berenike, the generic 'Opoc / Mons does not designate a mountain as in classical Greek or Latin, or as in the phrase Mons Claudianus, but it is a calque of the Egyptian $\underline{d} w .{ }^{180}$ Unaware of this Egyptian peculiarity, the editors of the latest edition of Ptolemy's Geography resume the old idea that Berenicidis mons could be an alternative name for "Mons Smaragdus." ${ }^{181}$ The Romans showed a double conservatism, first by reproducing, through the Greek, an Egyptian word, and secondly by maintaining the dynastic name of the port of Berenike (which is nothing exceptional). But they were highly innovative in renaming the region after this port so far out, while the desert was named during the Ptolemaic period by reference to Koptos, as shown by a

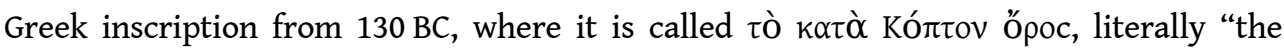
desert adjacent to Koptos." ${ }^{182}$ This expression is also the calque of the ancient Egyptian name $\underline{d} w$ Gbtyw. One can question this desire to put Berenike in the limelight at the expense of Koptos, while Roman Koptos was a thriving city with a monumental centre, whereas Berenike, devoid of an agricultural hinterland, was at the end of the earth. So much so that the governor of the Desert of Berenike was sometimes called, for short, the Prefect of Berenike, while its offices were at Koptos and he cannot often have come to 
Berenike. The idea behind the name was to suggest that Berenike, rather than on the borders of the empire, was now at the centre of a zone of Roman influence that extended well beyond it. There was perhaps some truth in this view, when we consider that, at least under Antoninus Pius, but perhaps even before, the Romans had a military base in the remote Farasan Islands.

\section{Origin of the toponym Myos Hormos}

Myos Hormos ${ }^{183}$ is a Ptolemaic foundation, but its picturesque name contrasts with the series of dynastic names conferred to Ptolemaic port foundations on the Red Sea. Agatharchides of Knidos (floruit c. $150 \mathrm{BC}$ ) attributes an alternative name to it, A $\varphi \rho \circ \delta i ́ \tau \eta c$ öpuoc, which, according to the version of his treaty on the Red Sea transmitted by

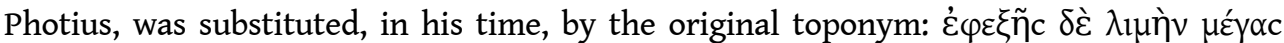

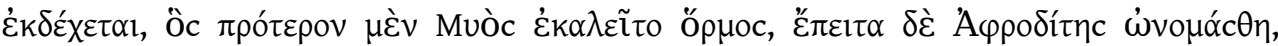
"immediately after, there comes a major port formerly known as the anchorage of the Mouse and which was called afterwards the anchorage of Aphrodite" (Phot., Bibl. 250.81). If we are to believe Agatharchides, this port offers a case of competition between a spontaneous, popular naming and one that has a more formal flavour and would have temporarily replaced the first. Mvòc "O $\mathrm{O} \mu \mathrm{oc}$ was definitively imposed during the imperial period. In most of its occurrences in the ostraca from Krokodilo, the complex toponym

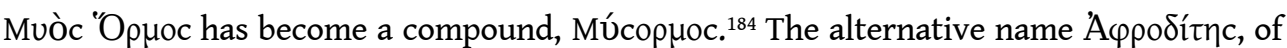
which one no longer hears in Roman times, remains an enigma: on what occasion and why would the toponym have been changed?

In versions of the treatise passed down by Diodorus Siculus (which mentions only the theotoponym) and Strabo, we also learn that the entrance to the anchorage is curved: ...

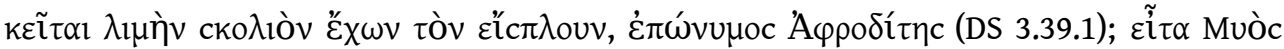

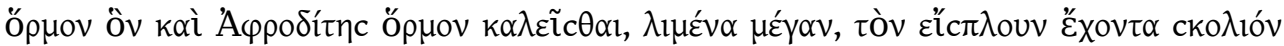
(Str. 16.4.5). Note that the word translated as anchorage, ǒpuoc, can be used figuratively to mean "refuge."

Scholars have been intrigued by the name Muòc "Oppoc. In the nineteenth century the Egyptologist H. Brugsch, followed by F. De Romanis, tried to explain it through the corruption of the Egyptian toponym mstj contained in the list of foreign peoples of Tutmosis III at Karnak. Not being an egyptologist, I will not dwell on this hypothesis that implies that Myos Hormos would have been a very old foundation, for which there is no archaeological evidence. Other researchers have proposed that in this toponym, the

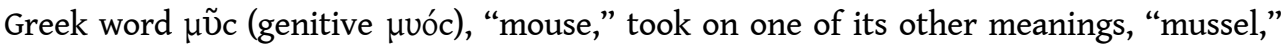
which would make more sense for a coastal town.

The map of the port published by the British mission of David Peacock and Lucy Blue suggested another hypothesis to me, which I have already presented in the article Myos Hormos of The Encyclopaedia of Ancient History: Myos Hormos had the distinction of having been built in an inland lagoon, now silted up. This lagoon was connected to the sea through a narrow opening where the coral-reef was interrupted because of the fresh water of the wadis floods that poured into the lagoon. The ships had to go through a curved channel, a feature described by Agatharchides of Knidos in such a way as to suggest that it was a striking sight for the eye witness. I think the image behind the name Myos Hormos is that of boats sneaking like mice into a small hole to find refuge. Some 
types of light ancient ships were, indeed, named after the mouse, such as myoparon or musculus. ${ }^{185}$

From the compound toponym Múcoppoc, known through the ostraca of the praesidia, is

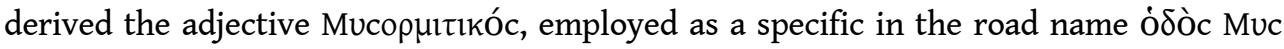

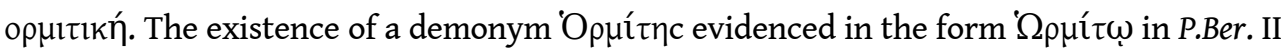
129, 22 and which refers to Myos Hormos, is hypothetical.

\section{Philotera, Philoteris and the Philoterion}

Ancient writers mention a port on the Red Sea, named after a sister of Ptolemy Philadelphus and founded by Satyrus, an explorer of the Trogodytike for capturing elephants. ${ }^{186}$ Stephanus Byzantius (Ethnica, ed. Meineke, p. 666) reports that besides $\Phi \backslash \lambda \omega \tau \varepsilon \dot{\rho} \alpha$, the suffixed form $\Phi \backslash \lambda \omega \tau \varepsilon p i ́ c$ is known, which was retained by Pomponius Mela, Chorogr. 3.80. ${ }^{187}$ Pliny, Nat. 6.168, cites Philoterias ${ }^{188}$ as an alternative name for an oppidum parvum otherwise known as Aenum. Ptolemy places $\Phi \iota \lambda \omega \tau \varepsilon$ pac $\lambda \iota \mu \eta ́ v$ directly south of Myos Hormos (Geogr. 4.5.14), whereas for Artemidorus and Pliny, Philotera is at the north end of the Gulf of Suez. Ostraca found in Myos Hormos and, to a lesser extent, at Maximianon and Krokodilo, show that the memory of the Ptolemaic princess remained significant in the area of Myos Hormos. Ostraca from Myos Hormos mention both a port called Philoteris (a boat went there from Myos Hormos) and a Philoterion (preceded by the definite article): are the two mixed up? Or was the Philoterion the temple of which scarce remains were found at Qusayr, a few kilometers south of Myos Hormos? Or is it the temple erected at the mining site of Bi'r Karim, where one of the wells was still supplying water to Qusayr in the nineteenth century? ${ }^{189}$ These hypotheses are discussed in the article by $\mathrm{W}$. Van Rengen, who also uses as evidence the letters on ostraca found at Maximianon including proskynemata to the goddess Philotera. Where do these letters come from? Considering that these proskynemata to Philotera matched those to Athena contained in the letters from Persou (Bi'r Umm Fawakhir), we considered at the outset that the letters citing Philotera were written in the praesidium that came after Maximianon in the direction of Myos Hormos, presumably the Simiou of our ostraca, if we accept the Ptolemaic origin of this toponym (it would derive from the name of the explorer Simmias). ${ }^{190}$ Although the aedes of that praesidium could have been called a Philoterion (thus, the aedes of Xeron, a fortlet where epistolary proskynemata address Athena, is called "the Athenadion" in a report on a nighttime incident), it is unthinkable that a military chapel enjoyed such fame that it was spoken of at Myos Hormos. The Philoterion was a larger feature; the name of the temple may have been extended by metonymy, to the place where it was. To evidence of Philoterion in the Myos Hormos ostraca we can add a letter found in Maximianon, which also contains one of these proskynemata before Philotera. ${ }^{191}$ It is, unfortunately, very fragmentary, but it suggests that letters arriving at Maximianon with proskynemata before Philotera may not have been written in a praesidium on the road, but at Philoterion, wherever it might be. Bi' $r$ Karim would not be a bad candidate: located south of the hodos Mysormitike, it is the same distance from Maximianon as Bi'r Sayyala (Simiou according to us) and the topography allows one to reach Maximianon without having to go round the mountain (Fig. 33 ). ${ }^{192}$ The surface ceramics date from the Roman period, ${ }^{193}$ but there are traces of Ptolemaic occupation. ${ }^{194}$ 
Fig. 33

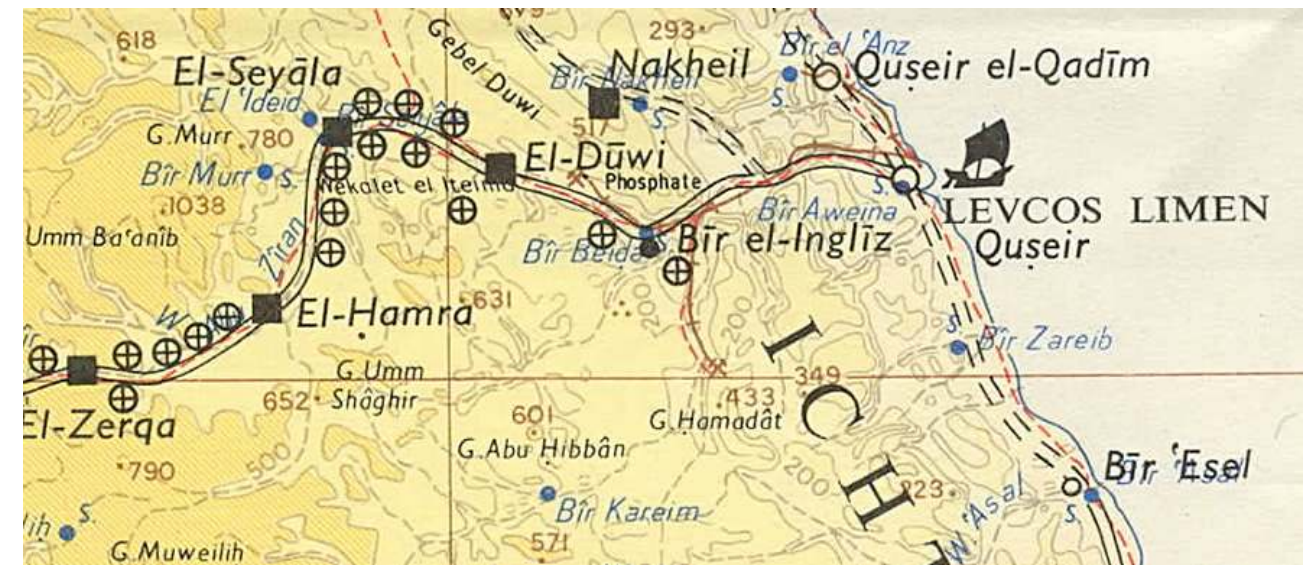

Maximianon (al-Zarqa' hamza) Myos Hormos, Bi'r Karim (from Meredith 1958).

(c) ALL RIgHTS RESERVED

The toponym Philotera / Philoteris does not appear in the ostraca of the praesidia except

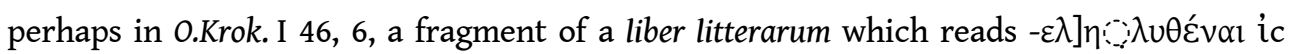
$\Phi \uparrow \lambda[$.

Finally, it should be noted that the name Philotera, which is not common in Roman Egypt, is carried by a young woman from the circle of Philokles, a food supplier and pimp who operated in the time of Trajan in the praesidia of the northern part of the Desert of Berenike.

\section{Unidentified topographic features}

$\mathrm{I} \pi \pi \mathrm{oc}$

O.Krok. I 120 is an activity report dated $7^{\text {th }}$ Pachon and written in the first person by K---s, a signifer, who is said to be going on reconnaissance with the cavalryman Marinus c $\tau 0 \tilde{v}$ "I $\pi \pi 0$. The infrared photograph made since the publication failed to provide a more accurate reading, but neither did it challenge it (Fig. 34): it remains possible and even quite probable. Since these daily notes are usually prepared by the curator praesidii, and since signifer is the only rank we know of for this non-commissioned officer, K---s is probably the curator himself, who took with him one of the cavalrymen of

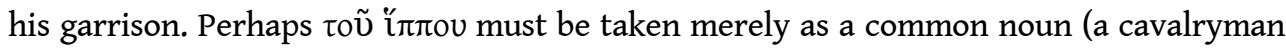
was attacked between two praesidia, the corpse of his horse left behind became a temporary landmark). However, we can read in an ostracon from Maximianon, in a

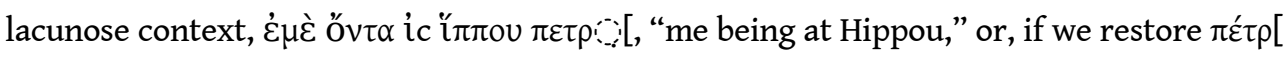
$\alpha v$, "at Hippou Petra," "the horse rock" (Fig. 35). 


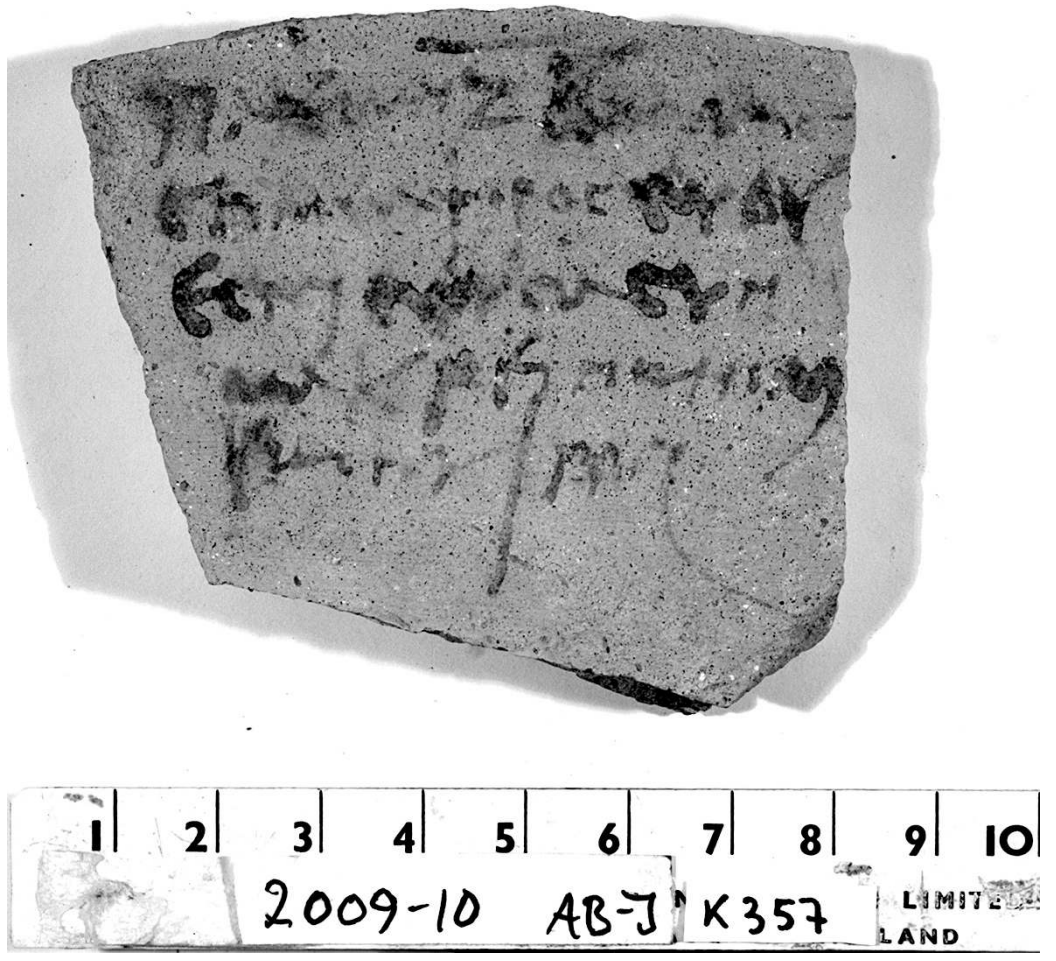

О.KROK. I 120.

(C) ADAM BÜLOW-JACOBSEN

Fig. 35

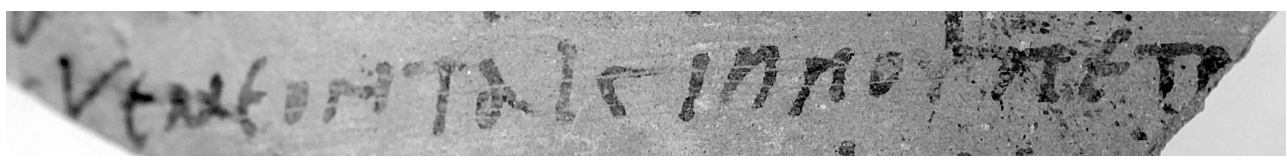

O.MAX. INV. 1099, 7.

C) ADAM BÜLOW-JACOBSEN

\section{Kóv $\omega \pi$ Toc}

Address of the destination of a letter found in Didymoi (Eic Kóv vorov, O.Did. 370, 1).

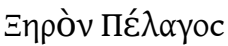

Homonym of a praesidium on the Berenike road, this site, probably near Mons Claudianus, is mentioned in three ostraca from the Trajanic period. One of them, O.Claud. I 141, gives the impression that it is a quarry. The author of the letter says that he passed Xeron Pelagos, where he met the centurion Crispus and another man who told him: $\alpha \alpha \tau \alpha c \pi \tilde{\omega} \mu \varepsilon v$

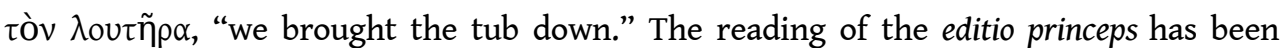
corrected, cf. BL XI 294 sq., where the verb has, however, been misunderstood. It is not about knocking down, i.e. starting the exploitation of the Louter quarry in Mons Claudianus, but bringing down a sink or tub from the quarry at Xeron Pelagos; the

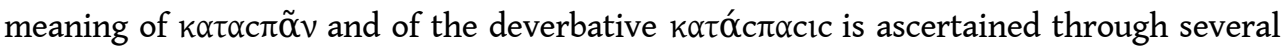
ostraca from Umm Balad (e.g. P.Worp 50, 11-12). 
A. Bülow-Jacobsen has suggested that this Xeron Pelagos could be the small quarry at Fatira Wadi al-Bayda $\left(26^{\circ} 44^{\prime} 01^{\prime \prime} \mathrm{N} / 33^{\circ} 19^{\prime} 25^{\prime \prime} \mathrm{E}\right)$, to which J. Harrell drew our attention. ${ }^{195}$ As the crow flies, the site is $18.30 \mathrm{~km}$ southwest of Claudianus, and $10.5 \mathrm{~km}$ northeast of Abu Zawal (Raïma?). There is no fortlet there, but cellae, some of which form a row. Further west, along the same wadi are other traces of Roman mining, where S.E. Sidebotham noted the inscription of the possible procurator Diadumenus. ${ }^{196}$

This toponym ("place of oysters / shells") appears only in O.Krok. I 47 (AD 109), in the

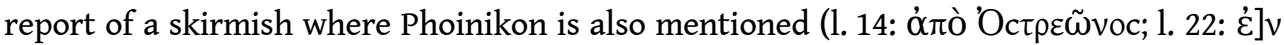

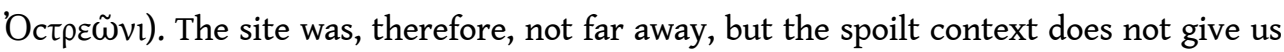
any more information.

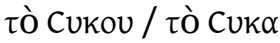

There are only two occurrences of this microtoponym variously spelled in two ostraca in the series of $\dot{\alpha} \pi \lambda_{\lambda}$ oyor $\dot{\delta} \rho \circ \varphi$ opíac (O.Claud. inv. 1530 and 2470 [Trajan]). Each time, only

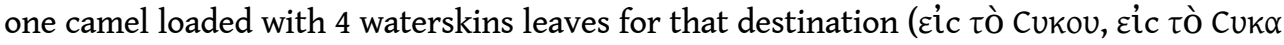
). Is the toponym derived from tò cũkov "fig"? It does not seem abbreviated (in this series, the abbreviations are always signalized with a graphic mark).

210 Two indeterminate toponyms result from misreadings and are ghost-names:

211 Ciopor

In O.Max. inv. 639, 12-13 (Route I, p. 57= SB XXVIII 17083) kic Cla ov (interpunction).

212 C $\mu \imath \lambda i ́ \alpha$

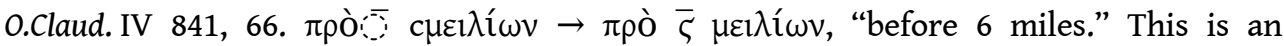
indication of distance. Distances were estimated in the desert in Roman miles. ${ }^{197}$

\section{Conclusion}

\section{Place and preterition of the generic element}

213 Generics to be considered in the analysis of the toponyms of the Eastern Desert are: ó $\delta$ ć,

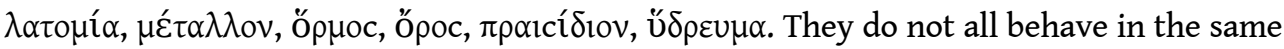
way in the formation of names: ódóc is necessary, while elision is almost the rule for

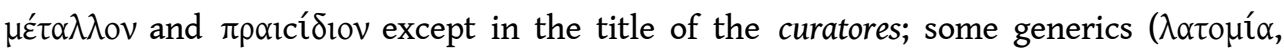

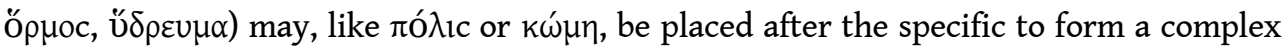
toponym (which I have chosen to highlight using the uppercase).

214 OSóc and ópoc normally precede the specific element which, except in the case of the via Hadriana, is a city name in the genitive. Oঠóc is never omitted.

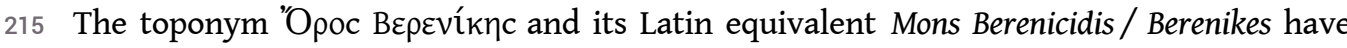
the particularity of being shortened in two ways: as part of the title of the territorial prefect, it can be reduced to one or the other of its two components: ع́ $\pi \alpha p x o c$ "Opouc

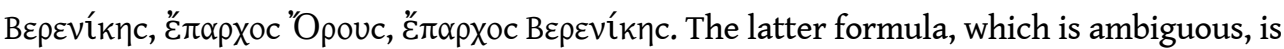
the least common; it may be early: of the four examples, all epigraphic, two are dated from the time of Augustus and Tiberius, respectively. ${ }^{198}$ Such metonymies are characteristic of administrative denominations (cf. the ancient city-states, and today Quebec or Mexico). When "Opoc / Mons is used alone to mean "Desert (sc. of Berenike)," it 
can be considered as an "appellative" in the narrow sense fit for toponyms. ${ }^{199}$ In toponyms, elision of the specific is normally encountered only in a local and familiar

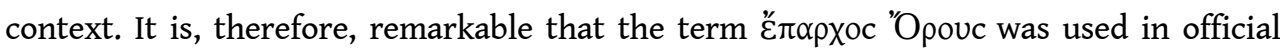
contexts and even outside the desert (petition P.Turner 34; غ̇лí dedication from Koptos I.Portes 86).

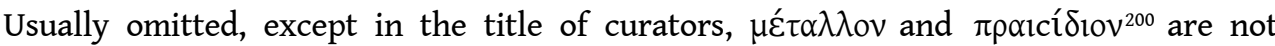
included in the toponym with two exceptions. ${ }^{201}$ They always precede the specific

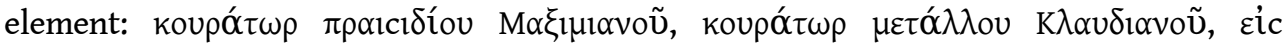

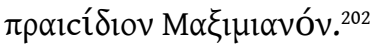

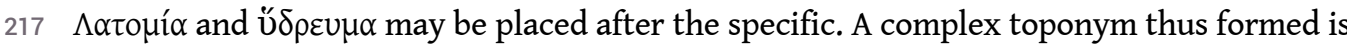
sometimes abbreviated. This is the case with A never happens when the specific component is an adjective (Kaıvì $\Lambda \alpha \tau o \mu$ ía, Kaıvòv

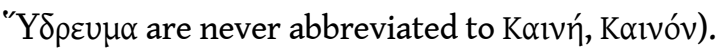

When a complex toponym is abbreviated, it is the second element that goes ('Opoc

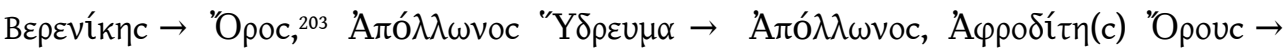

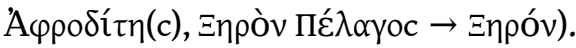

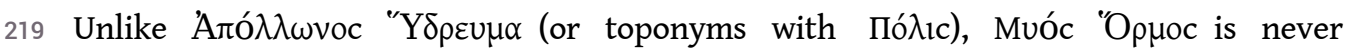
abbreviated to Muòc. However, it often becomes a compound and while the expected

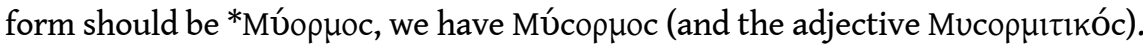

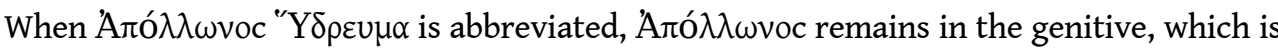

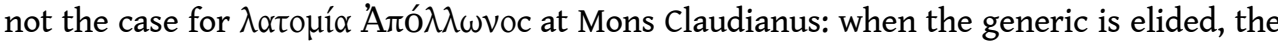
specific theophoric (as well as the anthropophoric) inflects. The rule is, therefore,

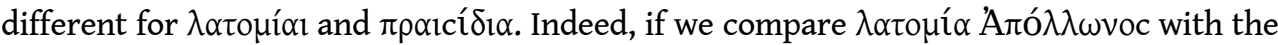

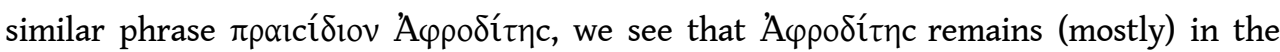
genitive when $\pi \rho \alpha ı c i ́ \delta ı v$ is omitted.

\section{The use of the article}

Analysis of the use of the article with toponyms is complicated by the scarcity of examples and by the flexibility of use. Even when the rule is that a toponym takes the article, it tends to be omitted after a preposition (this is not unique to toponyms, but all nouns), ${ }^{204}$ especially in documents where brevity is favoured, namely lists and accounts.

or obvious reasons, most of our topographic features are not included in the pages that Mayser ${ }^{205}$ dedicated to the use of the article for toponyms (countries and islands, towns and villages, mountains, rivers, sanctuaries, urban neighbourhoods, squares, etc., which rank in the category Lokalnamen).

Let us revisit the observations of Mayser:

Table 6

\begin{tabular}{|c|c|}
\hline countries, regions & 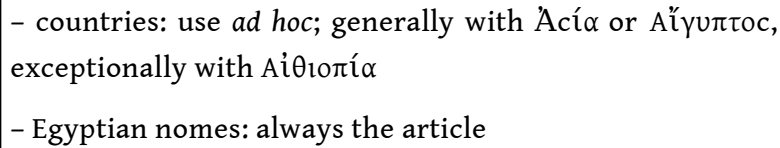 \\
\hline
\end{tabular}




\begin{tabular}{|c|c|}
\hline towns, villages & $\begin{array}{l}\text { do not take the article. Exceptions: } \\
\text { - in the case of the repetition of a toponym (anaphoric } \\
\text { article) } \\
\text { - when the toponym is a generic appellative, it may take } \\
\text { the article } \\
\text { - in an abbreviated phrase, a complex toponym } \\
\text { sometimes takes the article } \\
\text { - foreign toponyms sometimes take the article }\end{array}$ \\
\hline mountains, rivers & take the article, which can be omitted after a preposition \\
\hline $\begin{array}{l}\text { microtoponyms (urban areas, } \\
\text { temples, squares) }\end{array}$ & $\begin{array}{l}\text { take the article, also after a preposition (except in a } \\
\text { concise style) }\end{array}$ \\
\hline
\end{tabular}

USE OF THE ARTICLE BEFORE TOPONYMS

What do we observe in the Eastern Desert? The article is used more easily before toponyms that are or contain common nouns. The impression emerges that the article is stronger in the Ptolemaic ostraca from Bi'r Samut where, even after a preposition, $\alpha i$ $\Pi u ́ \lambda \alpha 1$ and $\tau o ̀ ~ C \alpha \pi \alpha \rho$ always take the article, and 'Pó $\mu v o c$ almost always, which suggests that these places were sites of minor importance. In the Roman period, the names of praesidia behave like names of cities or villages, and do not normally take the article, even when they are common nouns; though there is an exception, in the case of Eic $\tau \grave{\eta} v$

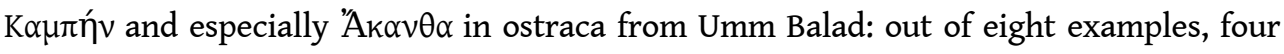
take the article.

The names of latomiai can take the article even if they are proper nouns (Eic tòv $\Delta$ ióvucov

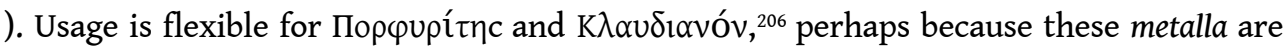
treated as regions. The name of the small metallon of Kaıvì $\Lambda \alpha \tau o \mu$ í $\alpha$ almost only appears as the destination address on amphoric tituli (about 70 examples); we note only one

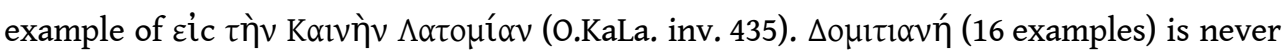
preceded by the article.

\section{The toponymic program of the Romans in the Eastern Desert}

The Romans have profoundly marked the Eastern Desert. They excavated the mountains from where they extracted huge monoliths for monuments built by the emperors. They appropriated space by equipping it with roads lined with fortlets in order to make the desert passable for travellers, and to implant an effective communication system, keeping the Beduins in check. Nevertheless, their toponyms are simple, when compared with the warlike names that the pharaohs of the Middle Kingdom gave their menenou (strongholds) in Nubia: "Who subjugates Setyou," "Who pushes Medjayou," "Who secures foreign countries," "Who kills the desert dwellers." 207 In Roman times, they relied more on the virtues of diplomacy than on the magical performative of words.

Neither did the Romans target a symbolic appropriation of space by replacing the existing names: they retained the old names, and even the dynastic Ptolemaic ones, even local cults that deified Ptolemaic princesses. 
- Kabalsi', praesidium on the road to Berenike;

- Kompasi, praesidium on the road to Berenike, former gold mine dating back to the Pharaonic era;

- Patkoua, praesidium, perhaps in Lower Nubia;

- Thonis Megale, praesidium, perhaps in Lower Nubia (Thonis is an Egyptian word);

- Raïma, praesidium on the road to Claudianus;

- Sabelbi, praesidium on the road to Porphyrites;

- Salaeis, a well close to Claudianus;

- Senskis, presumably a district of Smaragdos; ${ }^{208}$

- Tamostymis (Egyptian), mine or quarry in the area of Wadi al-Hammamat / Wadi alFawakhir.

One can add to this list the names of three metalla named after the material which was extracted and whose names belong to the language of populations who traditionally

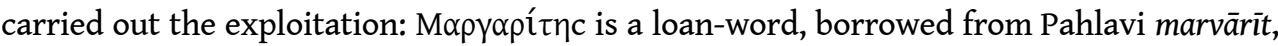
"pearl." This word is attested for the first time in Greek by Theophrastus, who was on the lookout for discoveries made by the explorers of Alexander the Great. But the main pearl fisheries were in the Persian Gulf. C $\mu \alpha \alpha_{\rho} \alpha \gamma \delta$ oc is an oriental word, already known by

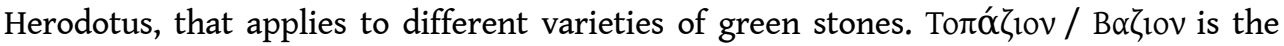
name of topaz and of St John's Island where it was mined. Among these three toponyms, it is the only one that could have local origins, if we follow Pliny, who thinks that it is, according to Juba, a word borrowed from the language of the Trogodytes (Nat. 37.109).209

Exotic names mentioned in the ostraca, some of which are Semitic, raise an insoluble problem. It is not possible to decide if they belong to a Beduin substrate predating the arrival of the Romans, who would have chosen to keep the names, or if they were bestowed by Roman officers eastern origin. In favour of the former hypothesis, we should look at the recurring microtoponym tò C $\alpha \pi \alpha \rho$, probably of Arabic origins, which refers, in ostraca from Bi'r Samut (third century BC), to a small site without a well, located in the vicinity of the Ptolemaic fort. Such toponyms probably betray the intervention of Beduin guides in the exploration of the desert by the Romans.

The Romans were moderate in their use of imperial eponymy, which they reserved for a few metalla and latomiai. Indeed, it was after a discovery phase of the physical geography of the Eastern Desert that they bestowed imperial names. The first metalla discovered were named after the material extracted from them, and the Romans gave thanks in Greek to the local Egyptian deity (Min) for the discovery of minerals. Apart from dynastic names, the toponyms they invented are apolitical, innocuous, and sometimes even rather bland (cf. the series of Kaine / Kainon). 


\section{BIBLIOGRAPHY}

References to the editions of texts relating to papyrology are those of the Checklist of Editions of Greek, Latin, Demotic, and Coptic Papyri, Ostraca, and Tablets (http://papyri.info/docs/checklist).

Brown V.M., Harrell J.A. 1995. "Topographical and Petrological Survey of Ancient Roman Quarries in the Eastern Desert of Egypt". In The Study of Marble and Other Stones Used in Antiquity ASMOSIA III. Y. Maniatis, N. Herz and Y. Bassiakis (eds.), Athens, pp. 221-234.

Chantraine P. 1993. La formation des noms en grec ancien, Paris.

Cockle W.E.H. 1996. “An Inscribed Architectural Fragment from Middle Egypt Concerning the Roman Imperial Quarries”. In Archaeological Research in Roman Egypt. D. Bailey (dir.), Ann Arbor 1996 (JRA Supplement 19), pp. 23-28.

Cuvigny H. (ed.), Brun J.-P., Bülow-Jacobsen A., Cardon D., Fournet J.-L., Leguilloux M., Matelly M.-A., Reddé M. 2003., La Route de Myos Hormos. L'armée romaine dans le désert Oriental d'Égypte, Le Caire.

Cuvigny H. 2005. "L'organigramme du personnel d'une carrière impériale d'après un ostracon du Mons Claudianus" Chiron 35, pp. 309-353.

Cuvigny H. 2014. "Le blé pour les juifs (O.KaLa. inv. 228)". In Le Myrte et la rose. Mélanges offerts à Françoise Dunand par ses élèves, collègues et amis. G. Tallet, Chr. Zivie-Coche (ed.), Montpellier, pp. 9-14.

Desanges. 2008. “Commentaire à: Pline l'Ancien”. Histoire Naturelle. Livre VI, CUF.

Dorion H., Poirier J. 1975. Lexique des termes utiles à l'étude des noms de lieux, Québec.

Gnoli R. 1971. Marmora Romana, Roma.

I.Ko.Ko.: Bernand A. 1972. De Koptos à Kosseir, Leiden.

I.Pan: Bernand A. 1977. Pan du désert, Leiden.

I.Portes: Bernand A. 1984. Les Portes du désert, Paris.

Kayser Fr. 1993. “Nouveaux textes grecs du Ouadi Hammamat”. ZPE 98, pp. 118-124.

Klemm R. \& Klemm D. 2013. Gold and Gold Mining in Ancient Egypt and Nubia. Geoarchaeology of the Ancient Gold Mining Sites in the Egyptian and Sudanese Eastern Deserts, Heidelberg.

Löfström J., Schabel-Le Corre B. 2005. "Description linguistique en toponymie contrastive dans une base de données multilingue". Le traitement lexicographique des noms propres, numéro spécial de la revue en ligne CORELA (http://corela.edel.univ-poitiers.fr/index.php?id=1167).

Loewe B. 1936. Griechische theophore Ortsnamen. Tübingen.

Maxfield V.A., Peacok D.P.S. 2001. The Roman Imperial Quarries. Survey and Excavation at Mons Porphyrites 1994-1998. I. Topography and Quarries, London.

Meredith D. 1958. Tabula Imperii Romani. Map of the Roman Empire Based on the International 1/1,000,000 Map of the World. Sheet N.G. 36. Coptos, Oxford.

Peacock D.P.S., Maxfield V.A. (eds.). 1997. Mons Claudianus 1987-1993. Survey and Excavation, I. Topography \& Quarries, Le Caire. 
Redard G. 1949. Les noms grecs en -TH $\Sigma$, -TI $\Sigma$ et principalement en -ITH $\Sigma$, -ITI $\Sigma$, étude philologique et linguistique, Paris.

Sidebotham S.E. 2011. Berenike and the Ancient Maritime Spice Route, Berkeley.

Sidebotham S.E., Zitterkopf R.E., Riley J. A. 1991. "Survey of the Abû Sha'ar-Nile road”, AJA 95, pp. 571-622.

Sidebotham S.E., Hense M., Nouwens H.M. 2008. The Red Land: The Illustrated Archaeology of Egypt's Eastern Desert, Cairo.

Schwyzer E. 1939. Griechische Grammatik I., München.

\section{NOTES}

1. This article has developed from a lecture presented on 13th April, 2013 as part of the interdisciplinary EPHE project "Lieux d'Égypte ou la toponymie égyptienne des pharaons aux Arabes" (2012-2014). I have been fortunate to benefit from a critical reading of my manuscript by Herbert Verreth, whom I thank for helping me with his many comments, and spotting many small blunders, omissions and inconsistencies; his judicious questions also helped me to clarify my thinking and deepen my reflection on some points. Naim Vanthieghem was kind enough to suggest to me a system that is both consistent and simple for the transcription of modern Arabic place names. Unless otherwise noted, all photographs were taken by Adam Bülow-Jacobsen, whom I also thank, as well as Mathilde Bru, for their help with the translation into English.

2. The ostraca are designated by a publication or an inventory number, preceded according to the provenance, by the abbreviations O.Claud., O.KaLa., O.Krok., O.Max., O.Did. O.Dios, O.Xer., O.Porph., O.MyHor. I thank Wilfried Van Rengen for allowing me to quote ostraca belonging to the two last corpora.

3. Excavations 2014-2016 funded by IFAO and MAE in the programme MAFDO now led by Bérangère Redon and Thomas Faucher.

4. I use the reference system of the latest edition of the Geography, which Germaine Aujac kindly drew to my attention: Klaudios Ptolemaios Handbuch der Geographie, Basel, 2006.

5. On the misinterpretations that were driven by the misunderstanding of mons and of the suffixed form Berenicis, see § 193-195.

6. On this metallon, see Sidebotham S.E., Barnard H., Harrell J.A., Tomber R.S. 2001, "The Roman Quarry and Installations in Wadi Umm Wikala and Wadi Semna." JEA 87, pp. 135-170.

7. On both sites, see $§ 27$.

8. These gold mining sites that often betray activity in the Ptolemaic period have never been explored. They are conveniently catalogued and described by Klemm, Klemm 2013, in their section entitled "Middle Central Group," pp. 68-146. Nowadays, they are threatened by a project of intensive mining exploitation which will concentrate on the so-called Gold Triangle, that is to say the part of the Eastern Desert comprised between the Qena-Safaga road and the Quft-Qusayr road.

9. I published them in O.Claud. III.

10. O.Claud. III 528 and 587.

11. Cockle 1996.

12. Cuvigny H. 2002, "Vibius Alexander, praefectus et épistratège de l'Heptanomie." CdE 77, pp. 238-248.

13. O.Claud. IV 848 and 850 .

14. O.Dios inv. 514 .

15. List $§ 228$. 
16. O.Claud. inv. 6179.

17. O.Claud. IV 854, 3 .

18. O.Claud. inv. 6366 .

19. Commented on in the section Praesidia (\$113-118).

20. Commented on in the section Praesidia (§ 115-117).

21. I.Pan 39: Annius Rufus (centurio) leg(ionis) XV Apollinaris praepositus ab Optimo Imp(eratore) Traiano operi marmorum monte Claudiano (...).

22. This casual error is not rectified in the apparatus criticus of the edition.

23. Cuvigny H. 2014, "Le système routier du désert Oriental égyptien sous le Haut-Empire à la lumière des ostraca trouvés en fouille". In La statio. Archéologie d'un lieu de pouvoir dans l'Empire romain, J. France, J. Nelis-Clément (ed.), Bordeaux, p. 254.

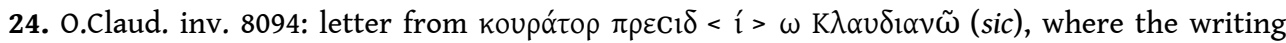
betrays a Latin speaker; and 0.Claud. II 372, letter of Aelius Serenus, who refers to himself as

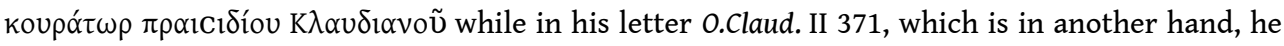

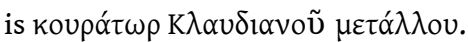

25. Cockle 1996.

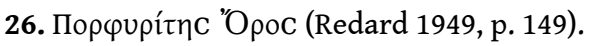

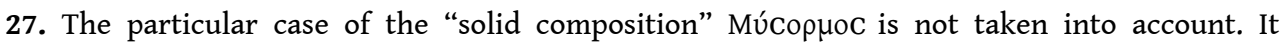
confirms a fact of popular pronunciation which removes the o of Muóc.

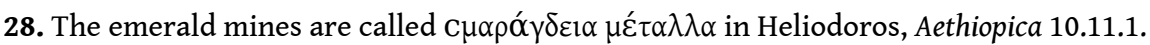

29. P. Flotté (Carte Archéologique de la Gaule 57/2. Metz, Paris 2005, p. 285) is hesitant about the reconstruction of l]agonam, probably because epigraphic references to lagona (pitcher) are always graffiti on an object. Why couldn't it be, however, the effigy in porphyry of a lagona?

30. It belongs to a group of masculine and feminine nouns formed on a nominal base, and characterized by the suffix - í $\eta \mathbf{c}$ for masculine, - $\tilde{\tau \imath c}$, for feminine. These denominational derivatives, that have proliferated from the Hellenistic period, are frequently trade-names, terms of botany, zoology, geology and geography. Just think of the names of the Egyptian nomes: $\dot{0}$

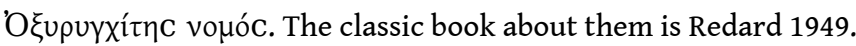

31. In principle, it should be derived from a base ó $\varphi ı$. But cf. Chantraine 1933, p. 311: "The suffix [sc. $-\alpha \tau \alpha c-\eta \tau \eta \mathrm{c}-\alpha \tau \eta \mathrm{c}]$ was sometimes extended to derivatives, although no base in long $\alpha$ was

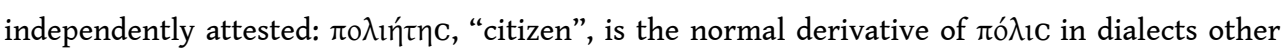

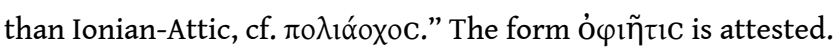

32. Dittenberger had previously proposed this idea (OGIS II 660, note 4). The toponymic use of the name of the material probably comes from a Greek usage: Pliny (Nat. 37.73.3) mentions an

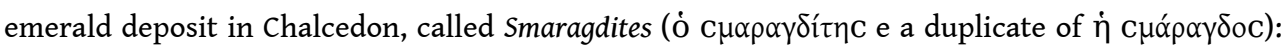
mons est iuxta Calchedonem, in quo legebantur, Smaragdites vocatus.

33. This was already the name of this metallon in the $3^{\text {rd }}$ century BCE, according to an ostracon

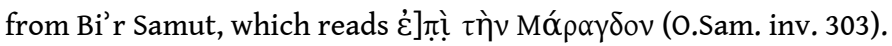

34. On this deserted island off Berenike, today Jazirat Zabarjad, see J.-L. Fournet's contribution in these proceedings.

35. OGI II 660, note 6.

36. Ranson G. 1961, Les espèces d'huîtres perlières du genre Pinctada (biologie de quelques-unes d'entre elles), Mémoires de l'institut royal des sciences naturelles de Belgique 67/2, pp. 11-12. On the distribution of pearl oysters in the Red Sea, see Donkin R.A. 1998, Beyond Price. Pearls and PearlFishing, pp. 29-36.

37. Probably in the anthropological sense of Beduins, which the word also has in Greek, but not in the ethnic sense.

38. Has exploitation by the people of the desert ever stopped in between? The presence of the Roman army in the first and second centuries in the emerald mines is attested by the discovery 
of elements of lorica squamata (Sidebotham, et al. 2008, p. 299). Have the Romans, when they took over the emerald mines, employed a Beduin task-force? Unfortunately, no ostracological discovery gives us clues about the composition of the workforce or the administrative framework. Local architecture is also a difficult issue: no fortified square building, but a multitude of small huts and several imposing official buildings. S.E. Sidebotham hypothesized that the large praesidium of Apollonos Hydreuma could house the garrison that controlled the exploitation of emerald mines (Sidebotham, et al. 2008, p. 301); but it is at a distance of $20 \mathrm{~km}$ from the village of Sikayt, a central inhabited area of one of the mining districts of Smaragdos, which consists of several. The modern name of Sikayt was suggested by Letronne from the epithet of Isis read by $19^{\text {th }}$ century travellers on a rock inscription of the site, now destroyed ( I.Pan 69). The best facsimiles, those of Nestor Lhôte and of Wilkinson are, respectively $\pi \alpha \rho \alpha \tau \eta \kappa v \rho 1$

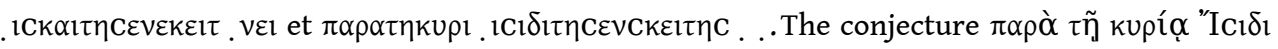
is reasonably safe; from the epiclesis which comes next, modern scholars deduced the toponym CEvCkıC, which would be the name of one of the exploitation areas of Smaragdos.

39. In the Erythrean area, the largest concentrations of Pinctada radiata are in Bahrain and Ceylon.

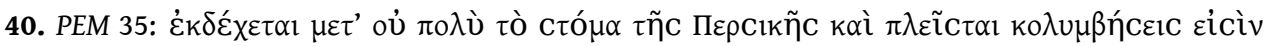

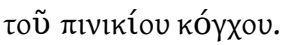

41. Hamilton-Dyer S.H. 2006, "Faunal Remains." In Myos Hormos-Quseir al-Qadim, Roman and Islamic Ports on the Red Sea. II. Finds from the Excavations 1999-2003, D. Peacock, L. Blue (eds.), Oxford, p. 273.

42. Especially when you know that an average of 500 oysters have to be sacrificed to get a few pearls (Strack J.E. 2008, "Introduction." In The Pearl Oyster. Southgate P.C. and Lucas J.S., Amsterdam, p. 13). In the Red Sea, we find such shell dumps on the islands of Dahlak and Farasan, at a more southern latitude (Sharabati D. 1981, Saudi Arabian Seashells: Selected Red Sea and Arabian Gulf Molluscs, VNU, p. 53). We know that there was, under Antoninus Pius, a Roman garrison at Farasan, but the oyster deposits there are not ancient.

43. The two scenarios are possible: Schörle K. 2015, "Pearls, Power and Profit, Mercantile Networks and Economic Considerations of the Pearl Trade in the Roman Empire." In Across the Ocean: Nine Essays on Indo-Mediterranean Trade, F. De Romanis, M. Maiuro (ed.), Leiden, p. 48 sq.

44. Schörle o.l., p. 48.

45. Schneider P. 2016, "Did Rome Engage in Pearling in the Red Sea? A Re-examination of the Two Dedications by Publius Iuventius Agathopus." ZPE 198, pp. 121-137. Unlike P. Schneider, I have no problem admitting that the ancients were able to classify the pearl fisheries in the category $\mu \varepsilon \dot{\tau} \tau \alpha \lambda$ ov because pearls are often likened by the authors to stones ( $\left.\lambda i \theta_{o l}\right)$.

46. Aelian gives the impression that it is a product derived from crystal. For other hypotheses about the nature of this terrestrial Indian pearl, see RE XIV 1700 (which favours the hypothesis that it must be bamboo resin tears).

47. The Roman Imperial Porphyry Quarries, Gebel Dokhân, Egypt, Interim Report 1998, p. 26

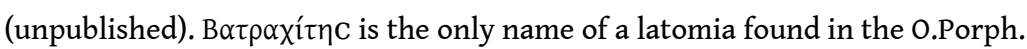

48. Batrachitas quoque Coptos mittit (Nat. 37.149). But in this passage, Pliny mentions gems, not an architectural material. Quoque is in reference to another gem exported by Koptos and that Pliny names the balanites: Balanitae duo genera sunt, subviridis et Corinthii aeris similitudine, illa a Copto, haec ab Trogodytica ueniens, media secante flammea uena, "As to the 'balanites', or 'acorn-stone', there are two varieties, of which one is greenish and the other like Corinthian bronze in its colour. The former comes from Coptos and the latter from the Cave-dwellers' country, and both are intersected through the middle by a bright red layer" (trans. D.E. Eichholz, Loeb). The description of Pliny, except for the fire-coloured vein, perfectly matches the greywacke of Wadi alHammamat, probably exported through Koptos, whose tones range from dark green to dark grey and, once polished, has a bronze patina. The "balanites" might be a ghost-word and a ghost-rock. Pliny knows greywacke under its correct name basanites: quem (lapidem) vocant basaniten, ferrei 
coloris atque duritiae (Nat. 36.58. This comparison with the colour of iron, not bronze, is less felicitous). Also Nat. 36.147.

49. Edictum Diocletiani de pretiis rerum venalium 33, 6 (Lauffer); 31, 6 (ZPE 34, 1979, p. 163-210).

50. Gnoli 1971, p. 133 called diorite extracted at Umm Balad granito verde fiorite di bigio; it appears in the Palatine palace: Gnoli highlights particularly the slabs of the pavement in the triclinium of the Domus Flavia and adds that this material was used to make floor or wall slabs and small objects such as columnettes.

51. The fragmentary dedication of the fort has an erased line where the name of the praefectus Aegypti would be expected: it must thus be Mettius Rufus, prefect between AD 89 and 92 . Furthermore, the oldest dated ostracon is from AD 91.

52. I do not take into account isolated mining, as on the walled rock of Badiya or near the praesidium of Qattar, which are mere exploratory tests (Brown, Harrell 1995, p. 224).

53. $27^{\circ} 9^{\prime} 11.71^{\prime \prime} \mathrm{N} / 33^{\circ} 17^{\prime} 0.24^{\prime \prime} \mathrm{E}$.

54. Coordinates according to Brown, Harrell 1995, p. 224.

55. http://www.eeescience.utoledo.edu/faculty/harrell/egypt/Quarries/Hardst_Quar.html.

56. I went there with A. Bülow-Jacobsen in January 2004.

57. Bagnall R.S., Harrell J.A. 2003, “Knekites.” CdE 78, pp. 229-235.

58. Gnoli 1971, p. 113. While Bagnall and Harrell perceive the colour of this material as pale, for Gnoli, who calls it porfido serpentino nero, it is a dark rock.

59. $26^{\circ} 56^{\prime} 30^{\prime \prime} \mathrm{N} / 33^{\circ} 14^{\prime} 39^{\prime \prime}$ E. On the diorite from Umm Shejilat, cf. Gnoli 1971, p. 126; Brown, Harrell 1995, p. 224. It is called granito della colonna, the most famous object made in this material being a small column (actually a baluster) brought from the Holy Land in the thirteenth century by Cardinal Giovanni Colonna; assumed to be the column of the scourging of Jesus, it is kept in the church of St. Praxedes in Rome (one easily finds a picture on the web by searching Colonna della flagellazione). The discoverer of this quarry, an Egyptian engineer, reports a Roman well at Umm Shejilat (Gnoli 1971, p. 126, n. 2).

60. http://www.eeescience.utoledo.edu/faculty/harrell/egypt/Quarries/Hardst_Quar.html.

61. The fact that Germanike Latomia was a delivery address for a camel driver delivering supplies indicates that the feature to which this place name refers is a metallon, not a latomia in its usual meaning of a specific quarry-site.

62. In the ostraca from Umm Balad, we have five occurrences of the spelling A $A \alpha \beta$ - and four of A $\alpha \beta$-.

63. On the alabarchai, tax farmers who were sometimes fabulously rich, see Burkhalter F. 1999, "Les fermiers de l'arabarchie : notables et hommes d'affaires à Alexandrie." In Alexandrie: une

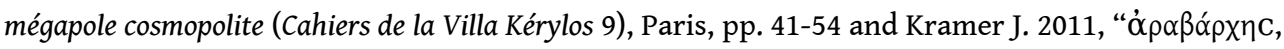
$\dot{\alpha} \lambda \alpha \beta \alpha ́ p x \eta c / a r a b a r c h e s$, alabarcha," in id., Von der Papyrologie zur Romanistik (APF Beiheft 30), Berlin - New York, pp. 175-184.

64. J. Gascou, pers. comm., suggests that Arabarches falls into the category of auspicious anthroponyms, rich arabarches being proverbial.

65. In eight cases, six without the article (among which three examples of the phrase cic A $\lambda \alpha \beta \alpha ́ \alpha \chi \eta v)$ and two with (including P.Worp 20).

66. $§ 30$.

67. List of quarries: Peacock, Maxfield 1992, pp. 178-189. The numbers are shown on the plan published in O.Claud. IV, p. 10.

68. Organizational chart belonging to the same series as the document I published in Cuvigny 2005.

69. § 105.

70. Peacock, Maxfield 1992, p. 225.

71. I.Pan $45=$ SEG XLVII 2122 (4), where the unfortunate resolution A $\pi 0 \lambda(\lambda \omega ́ v 10 C)$ is corrected.

72. I.Pan 40, cf. O.Claud. I, p. 48; Peacock, Maxfield 1997, pp. 189 and 221. 
73. As the beginning of line 31, which should be in double straight brackets: $\llbracket$.

74. BIFAO 1993, p. 64 sq. = SEG XLIII 1121.

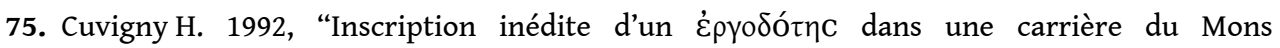
Claudianus." Itinéraires d'Égypte. Mélanges offerts au Père Maurice Martin, Cairo, pp. 73-88 (= SEG XLII 1576).

76. Swinnen W. 1968, "Philammon, chantre légendaire, et les noms gréco-égyptiens en -ammôn." Antidorum W. Peremans, Studia Hellenistica 16, pp. 237-262, sp. 260.

77. Les conditions de pénétration et de diffusion des cultes égyptiens en Italie, Leiden 1972, p. 44, n. 4 et p. 442.

78. SB XIV 11342, 6; SB XXVI 16726, 2.

79. IK XI1, 33, 4-5.

80. Rehm A. 1958, Didyma, II. Die Inschriften, Berlin, No. 502.

81. I thank Marie-Pierre Chaufray, Willy Clarysse and Françoise Dunand for helping me unravel this tangled question.

82. I thank Claire Le Feuvre and Sophie Minon for providing this citation.

83. On the distinction between memorial and anecdotal toponyms, see Dorion, Poirier, 1975, s.v. "anecdotique."

84. O.Claud. IV 850, 853, 857.

85. Except in the Anonymous of Ravenna (Caenopoli).

86. Mayser, Grammatik II.2.1, p. 14.

87. Mayser, Grammatik II.2.1, p. 17 sq.

88. In this they follow the recommendations of the Second United Nations Conference on the Standardization of Geographical Names (see Dorion, Poirier 1975, p. 55).

89. Cuvigny 2005.

90. O.Claud. IV 841, introduction.

91. Lines 19 and 111.

92. Cf. § 104

93. John Rea observed that a reading Паүкои is not excluded.

94. But probably not the Prefect of Berenike, who seems to be at this time Arruntius Agrippinus ( O.Krok. I, p. 137 ff.).

95. It is only after seeing the graffito, after a month of excavation, that I made the connection between the shape of the rock and the curious name of the praesidium.

96. J. Gascou, JJP 24, p. 14 n. 4 ; J.-L. Fournet, REG 105, 1992, p. 236 ; J.-L. Fournet, "Coptos grécoromaine à travers ses noms." In Autour de Coptos (Topoi Supplément 3), 2002, p. 52 sq.

97. Chantraine 1933, p. 116.

98. Cuvigny (ed.) 2003, I, p. 55; II, p. 281 sq.; p. 383.

99. H.-J. Thissen sees in this toponym the Egyptian name for galena ("Demotische Graffiti aus dem Wâdi al-Hammâmât." Enchoria 9, 1979, p. 63-92, ad 88).

100. Reinach A.J. 1910, Rapports sur les fouilles de Koptos (janvier-février 1910), Paris, p. 43.

101. Guéraud O. 1942, “Ostraca grecs et latins de l'Wâdi Fawâkhir." BIFAO 41, pp. 141-196, n 14 (= SB VI 9017). Cf. Cuvigny (ed.) 2003, I, p. 196.

102. This does not necessarily mean that the soldiers were still stationed in the village: the proskynemata may have been left by travellers. Ostraca found in the village indicate the presence of a mixed population of quarry workers and soldiers, but none are dated (Kayser 1993, No. 20-60= SB XXII 15660-15700).

103. I owe this remark to Herbert Verreth.

104. In theory, it could also be the genitive of Cínıoc, name of a Syrian god (Route I, p. 56).

105. Brun 2004, p. 135.

106. Brun 2004, p. 133

107. O.Did. 54, c. AD 96. 
108. O.Did. 458; O.Dios inv. 264.

109. The phrase "Berenike of the Trogodytes" (French Bérénice des Trogodytes) has been made up after Pliny, Nat.2.183, Berenice urbe Trogodytarum, which is not a complex toponym, urbe Trogodytarum being only an explicative gloss in apposition.

110. ILS $2483=$ I.Portes 56 .

111. http://www.trismegistos.org/nam/detail.php?record=1427.

112. For the gold mines at Daghbagh see Klemm, Klemm 2013, pp. 161-168 (the authors interpret the mills as ore washeries); however, cf. B. Redon, "Samut North: 'heavy mineral processing plants' are mills." Egyptian Archaeology 48, 2016, pp. 20-22.

113. O.Dios inv. 922.

114. O.Dios inv. 53. According to Mayser, Grammatik II .1, 8, neuter plural article $\tau$ ó used before a personal name means "the house of, the property of." But the formula can also designate the

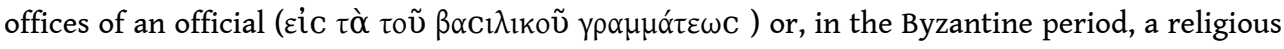

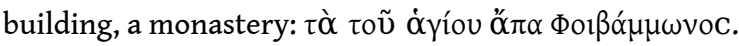

115. Cf. § 206.

116. For the Early Roman Empire, it is mainly in Latin that I found poetic reminiscences, e.g. Ovid. Met. 2.235: mare contrahitur siccaeque est campus harenae /quod modo pontus erat. Manilius, Astronomica 5.688: congeritur siccum pelagus. Lines 448-449 of book 5 of Oracles Sibyllins, antipagan poem probably composed in Alexandria by a Jew between 80 and 130, use the same image: ع́c $\tau \alpha$

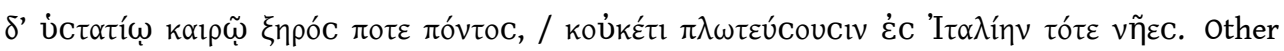
poetic examples can be found in Greek, but in the Byzantine period.

117. Bülow-Jacobsen A. 2013, "Communication, Travel, and Transportation in Egypt's Eastern Desert during Roman Times ( $1^{\text {st }}$ to $3^{\text {rd }}$ century AD)." in Desert Road Archaeology in Ancient Egypt and Beyond, Fr. Förster, H. Riemer (eds.), Köln, p. 561, n. 3.

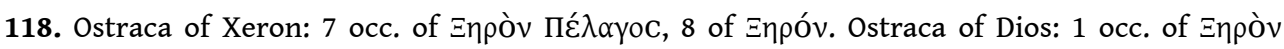

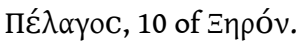

119. A prosopographic overlap allows the date of 216-219. Phalakron was abandoned in the early third century, before the time characterized in Didymoi, Dios and Xeron by rubbish deposits inside the fort, and by the uncontrolled proliferation of loculi.

120. O.Xer. inv. 257 (post register); O.Xer. inv. 956, 5 (soldier's letter).

121. O.Dios inv. 818 (list of praesidia from Apollonos to Phoinikon); O.Xer. inv. 488.

122. Sidebotham 2011, p. 161.

123. mox ad Novum Hydreuma (Nat. 6.102).

124. Meredith D. 1953, "The Roman remains in the Eastern Desert of Egypt (continued)," JEA 39, pp. 100-101.

125. Sidebotham 2011, pp. 130, 149, 163.

126. Sidebotham 2011, p. 97. Plan of this hafir: Sidebotham S.E., Zitterkopf R.E. 1995, "Routes through the Eastern Desert of Egypt." Expedition 37/2, p. 44, Fig. 6.

127. In Sidebotham S.E., Gates-Foster J., Rivard J.-L. (eds.) 2018 (forthcoming), The Archaeological Survey of the Desert Roads between Berenike and the Nile Valley: Expeditions by the University of Michigan and the University of Delaware to the Eastern Desert of Egypt, 1987-2015, Boston.

128. So Meredith, JEA 38, 1953, p. 100. John Ball, in a confused note, considers that Pliny reverses the names of the two last stages of the road and erroneously calls Novum Hydreuma "Vetus Hydreuma" (J. Ball, Egypt in the Classical Geographers, Cairo 1942, p. 83). But then where would be, according to Ball, the true Vetus Hydreuma?

129. O.Claud. inv. 8828, found in the "Hydreuma": cic " $\mathrm{P} \alpha[\mu \alpha]$.

130. O. Claud. inv. 2238. A shaduf in a desert way station, see Fig. 13.8 in Sidebotham et al. 2008, p. 320 (reconstruction of the way station of Wadi Wadi Abu Shuwayhat, also called Tala't alZarqa', on the road to Claudianus).

131. Sidebotham S.E. 2011, Berenike and the Ancient Maritime Spice Route, UCP, pp. 119-120. 
132. Klemm, Klemm 2013, pp. 70-74.

133. I thank Rosemarie Klemm for kindly providing me with the original photo.

134. The editor, Jean Bingen, still doubts whether it is Raïma, because the author of the letter also acknowledges receipt of a water amphora: why indeed send water to Raïma? But it is undoubtedly special water. This is certainly not an amphora with water to water the vegetables.

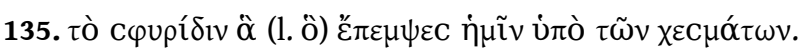

136. The papyrological occurrences of $\dot{\rho} \alpha$ koc et de $\dot{\rho} \alpha \kappa \alpha ́ \delta 10 v$ are gathered together and discussed by R. Mascellari, Lex.Pap.Mat. III, 2 (Comunicazioni dell'Istituto Papirologico Vitelli 12, 2016), pp. 151-159.

137. In the Eastern Desert, it is the rock hyrax, Procavia capensis, not the bush hyrax Heterohyrax brucei (Yves Lignereux, email 17/07/2016). This small mammal is the size of a rabbit and it is hard to imagine that its droppings were used to fertilise a vegetable garden.

138. Gignac F.R. 1981, A Grammar of the Greek Papyri of the Roman and Byzantine Periods, II, Morphology, Milan, p. 66 sq. Robert Daniel, whom I consulted about this remark and would like to thank, cautioned me that Gignac cites only $\chi \varepsilon$ í $\lambda \varepsilon \alpha$ in PGM 4401, which is actually the only example, and that it is interpreted as a poetic reminiscence: in prose passages of magical papyri, we have the regular form $\chi \varepsilon i ́ \lambda \eta$.

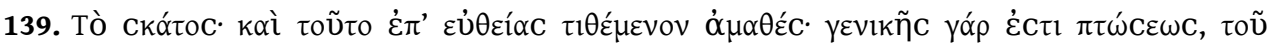

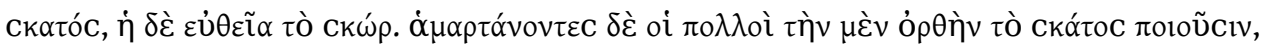

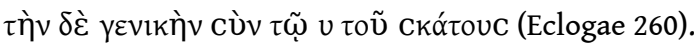

140. While the use of goat, sheep, horse, cattle, camel, dog and cat dung is constantly attested by the authors and in medical texts, Pliny is the only source mentioning pig excrement that is reported by Durling R.J. 1999, "Excreta as a remedy in Galen." In Tradition and Traduction. Hommage à Fernand Bossier, R. Beyers et al., Leuven, p. 28. After describing the different ways of preparing wild boar droppings for medication, Pliny (28.138) simply adds that pig manure has properties similar to those of wild boar manure, which gives the impression that it might serve as a substitute (proximam suillo fimo putant vim). Boar dung which, unlike that of pigs, is frequently cited in the medical literature, was, according to Pliny, used against bruises and injuries due to falls, so that charioteers would commonly use it. For this reason, Nero would put on a show of consuming it.

141. O.Claud. inv. 7038 mentions a curator of Kampe.

142. Gendron St. 2006, La toponymie des voies romaines et médiévales. Les mots des routes anciennes, Paris, p. 42 sq.

143. O. Claud. inv. $8851,8875,8890,8908,8923$.

144. Sidebotham, et al. 1991, p. 582 sq. (with plan).

145. Maxfield, Peacock 2001, pp. 215-237. Well: p. 236 sq.

146. Maxfield, Peacock 2001, pp. 200-202.

147. Photo in Maxfield, Peacock 2001, Fig. 5.13 p. 201.

148. A. Bülow-Jacobsen, per os.

149. My two informants, to whom I could only show the photo cited n. 147, are of different opinions. L. Nehmé thinks that camels could use that mule track, "provided the path is wide enough, as the photo suggests. There are trails of this type around Petra, on plots of caravan routes" (email of $28^{\text {th }}$ June 2016). But Carlo Bergmann, who travelled across the Sudanese and Egyptian deserts with small groups of camels, is less certain: "Such trails are not really suitable for camels. Firstly, the trails seem to be quite narrow. Camels walk in amble and would be afraid to follow such lanes, especially if these (like the one in the middle) are running almost parallel to a quite steep slope and if the beasts carry heavy loads. Secondly, the trail in the centre seems to pass over very rough gravel which fills the front of the picture. Anyone caring for his camels would have cleared from the track at least a few of the roughest stones. (...) The hoofs of donkeys would not require such clearance" (email of $18^{\text {th }}$ September 2016). 
150. Sidebotham et al. 1991, p. 577 sq. (with plan); Maxfield V.A. 1996, "The Eastern Desert Forts and the Army in Egypt during the Principate." In Archaeological Research in Roman Egypt, D.M. Bailey (ed.), JRA Suppl. 19, pp. 17-19.

151. Sidebotham et al. 1991, p. 577.

152. Sidebotham et al. 1991, p. 577.

153. Sidebotham et al. 1991, p. 577.

154. This is precisely the number of ostraca mentioning these names.

155. O.KaLa. inv. 483.

156. = p. 695 in Müller's edition.

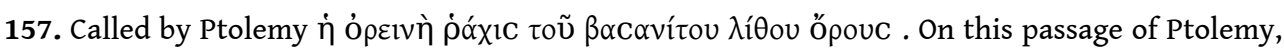
see $\S 22-23$. Remarkably, Mons Claudianus is not in this list (and does not appear at all in the Geography).

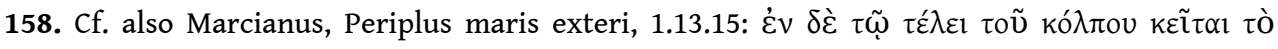

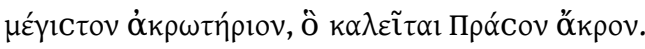

159. "The Ostraca from Umm Balad," PapCongr. XXVIII (forthcoming).

160. Masson O. 1976, "Grecs et Libyens en Cyrénaïque d'après les témoignages de l'épigraphie." Ant. Afr. 10, p. 60.

161. O.KaLa. inv. 549 .

162. O.KaLa. inv. $783 ; 785 ; 811$. The last two letters are written by Turranius, who we have reason to believe is curator of Prasou.

163. On the Turranius' letters, see Cuvigny 2014.

164. See the section, s.v. 'Akó $v \theta 10 v$, 'A $\alpha v \theta \alpha$, "L'Acacia".

165. Five occurrences without the article, and three with it.

166. I owe this explanation to the perspicacity of Jean-Louis Perpillou.

167. Peacock, Maxfield 1997, pp. 151-154.

168. Bingen J., Jensen S.O. 1992, "Mons Claudianus. Rapport préliminaire sur les cinquième et sixième campagnes de fouille (1991-1992)." BIFAO 92, sp. p. 16.

169. O.Claud. inv. 1538, 6, published in Cuvigny 2005. The reading ] . IV 695, 3 seems doubtful given the infrared photo.

170. O.Claud. inv. 1287, 1288, 1306, 1378, 1530, 1801, 3322.

171. In the case of the minor road to Akanthion, this reference point is Claudianus.

172. Valat D. 2008, "Interférences onomastiques et péri-onomastiques dans les Res Gestae d'Auguste." In Bilinguisme gréco-latin et épigraphie, Fr. Biville, J.-Cl. Decourt, G. Rougemont (eds.), Lyon, p. 249. That criterion allows a more precise date for I.Mylasa 214 (=IK 35), for which the editor does not offer a date and which McCabe, in the Searchable Greek Inscriptions, dated second

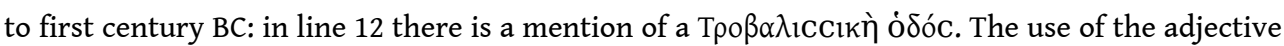
suggests that this inscription is in any case later than the Roman takeover of Caria that occurred at the end of the Republic. Another indication of the Roman influence is provided in line 1 by the

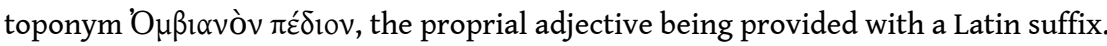

173. P.Oxy. XLV 3243, 14.

174. Below are the last lines of the inscription: per eosdem qui supra scripti sunt, lacci aedificati et dedicati sunt: Apollonos Hydreuma VII K(alendas) Ianuarias, Compasi K(alendis) Augustis, Berenicide XVIII K(alendas) Ianuar(ias), Myos Hormi Id[ib]us Ianuar(iis) castram aedificaverunt et refecerunt.

175. In the case of these two Latin poets, the use of the suffixed form is explained perhaps only by the needs of the metre.

176. Chantraine 1933, p. 339. None of the examples cited by Chantraine is derived from a town or village name. The RE correctly points out that Berenicis in the two Latin poems is the city itself, not its surroundings (s.v. Berenike, col. 282 [8]).

177. De Romanis F. 1996, Cassia, Cinnamomo, Ossidiana, Roma, p.175, n. 23. This interpretation is further vitiated by interpreting laccus as "well" instead of tank. 


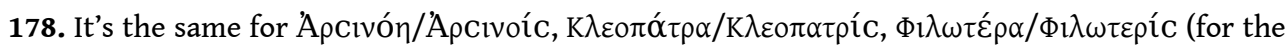
latter name, see § 201-203).

179. Message from 15 April 2013.

180. When one thinks about it, the Greek and Latin did not have a noun to refer to this

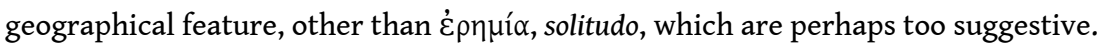

181. Klaudios Ptolemaios, Handbuch der Geographie, A. Stückelberger, G. Grasshoff [eds.], I, Basel 2006, p. 425, n. 123. H. Verreth (pers. comm.) observes that this confusion must go back to the Barrington Atlas 2000, pl. 80, F4 (Berenicidis Mons= Smaragdos Oros). This edition of the Geography also wrongly distinguishes between Berenike in 4.5.15 and Berenike Trogodytika (with reference to Calderini, Diz. Geogr. II.40 and K. Sethe, Berenike [5] in RE 3.1 [1897], 280 ss.).

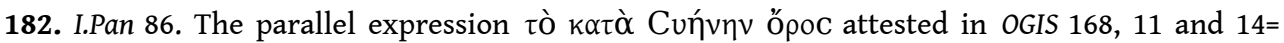
I.ThSy. 244, 40 and 54 (AD 115 ) does not designate a vast desert region such as the desert of Koptos or Berenike, but only the quarry area of Syene; it is a descriptive gloss rather than a toponym and, if we consider it as a toponym, it could be the name of a metallon.

183. Today Qusayr al-Qadim.

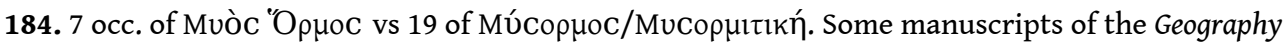

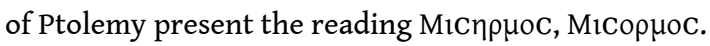

185. The late David Peacock liked this idea and wrote back: "I think your suggestion is a good one. The entrance is narrow and divers have seen a reef in the middle. Compared with the other Red Sea ports it must have been a pain to get into -and there is the wreck at the mouth as proof!" (Email of $27^{\text {th }}$ November 2010).

186. Artemidorus ap. Strabon 16.4.5.

187. On this passage of Pomponius Mela, see Cohen G.M. 2006, The Hellenistic Settlements in Syria, The Red Sea Basin, and North Africa, UCP, p. 312.

188. Mox oppidum parvum est Aenum - alii pro hoc Philoterias scribunt. But Philoterias (H. Verreth pointed out to me that it must be an accusative plural) is a conjecture by Mayhoff: all manuscripts give the final -ria or - rias, while the beginning of the name is more or less corrupted. On Philotera see the comments of J. Desanges in his edition of Book VI of Pliny (CUF 2008), p. 53.

189. Prickett M. 1979. In Quseir al-Qadim 1978. Preliminary Report, D.S. Whitcomb, J.H. Johnson,

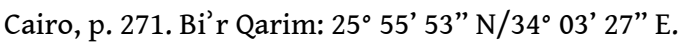

190. A. Bülow-Jacobsen, in Cuvigny 2003, I, p. 56.

191. O.Max. inv. 1149. We read line 7: $\dot{\alpha} \lambda \lambda \dot{\alpha} \dot{\varepsilon} v \tau \tilde{\omega}$ $\Phi \iota \lambda \omega \tau \varepsilon[\rho i ́ \omega]$ ].

192. I make my argument using the map of Meredith, having never been to Bi'r Karim myself.

193. Whitcomb D.S., Johnson J.H. 1982, Quseir al-Qadim 1980. Preliminary Report, Malibu, p. 292.

194. See Van Rengen's article in these proceedings, $\S 16$. The site of Bi'r (Wadi) Karim is described, with a good satellite image, in Klemm, Klemm 2013, pp. 148-151.

195. Email $20^{\text {th }}$ March 2017. Non vidimus.

196. Sidebotham S.E. 1996, "Newly discovered sites in the Eastern Desert." JEA 82, pp. 190-192 and pl. XIX. A. Bülow-Jacobsen and I have vainly sought this inscription Friday, January $25^{\text {th }}, 2011$.

197. See O.Did. 44 and the letter of Nemesous O.Did. 400, which shows that even a procuress referred to this unit of measure.

198. I.Pan 51 (AD 11), ILS 2698 (Tiberius), I.Pan 68 (AD 76/77), I.Memnon 14 (s.d.).

199. See $\S 104$.

200. No more than $\mathrm{c} \tau \alpha \theta \mu$ óc in the Ptolemaic era: this is the noun which refers to desert way stations in the ostraca from Bi'r Samut, which, in the third century BC, is one of these $c \tau \alpha \theta \mu o$ í on the road from Edfu to Berenike. The only appellative used then as a generic element in a complex toponym is " $\curlyvee \delta \rho \varepsilon u \mu \alpha$. 


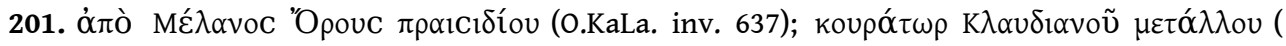
O.Claud. II 371).

202. SB XXVIII 17096, 5-6.

203. But by exception (see above) the ellipse may affect the generic in the phrase ع́ $\pi \alpha \rho x o c$

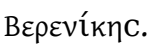

204. Mayser, Grammatik II.2.1, p. 14.

205. Grammatik II.2.1, pp. 13-18.

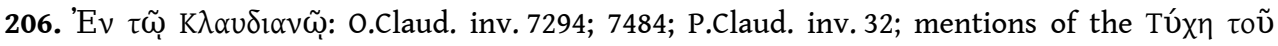

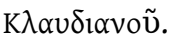

207. Somaglino $\mathrm{Cl}$. 2017, "La toponymie égyptienne en territoire conquis: les noms-programmes des menenou." In Du Sinaï au Soudan. Mélanges offerts à Dominique Valbelle, N. Favry et al. (eds.), Paris, pp. 231-244. The antecedent of "who" is more likely the Pharaoh than the fortress itself. 208. See supra, n. 38.

209. J. Desanges doubts this interpretation and believes Pliny misunderstood its source, and that

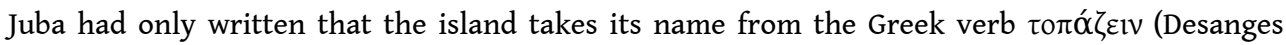
2008, p. 62).

\section{AUTHOR}

\section{HÉLÈNE CUVIGNY}

CNRS / IRHT 